Andrews University

Digital Commons @ Andrews University

2005

\title{
Ministry to the Black Middle Class: Strategies for Churches in Transition
}

Dedrick L. Blue

Andrews University

Follow this and additional works at: https://digitalcommons.andrews.edu/dmin

Part of the Practical Theology Commons

\section{Recommended Citation}

Blue, Dedrick L., "Ministry to the Black Middle Class: Strategies for Churches in Transition" (2005).

Professional Dissertations DMin. 517.

https://dx.doi.org/10.32597/dmin/517

https://digitalcommons.andrews.edu/dmin/517

This Project Report is brought to you for free and open access by the Graduate Research at Digital Commons @ Andrews University. It has been accepted for inclusion in Professional Dissertations DMin by an authorized administrator of Digital Commons @ Andrews University. For more information, please contact repository@andrews.edu. 


\begin{abstract}
MINISTRY TO THE BLACK MIDDLE CLASS: STRATEGIES

FOR CHURCHES IN TRANSITION
\end{abstract}

by

Dedrick L. Blue

Adviser: Clifford Jones 


\section{ABSTRACT OF GRADUATE STUDENT RESEARCH \\ Dissertation}

Andrews University

Seventh-day Adventist Theological Seminary

Title: MINISTRY TO THE BLACK MIDDLE CLASS: STRATEGIES FOR CHURCHES IN TRANSITION

Name of researcher: Dedrick L. Blue

Name and degree of faculty adviser: Clifford Jones, D.Min., Ph.D.

Date completed: July 2005

\section{Problem}

Between 1944 and 1997 over 1 million Black people in the United States rose from poverty to middle class status. Increased upward mobility has brought an increased social mobility. Middle class Blacks are moving into close proximity to predominantly White suburban Seventh-day Adventist churches. Simultaneously, the out-migration of the Black middle class from urban areas to suburbia has created not only an economic drain, but also has fostered class tensions within the Black urban church. If churches are to be successful in the recruitment and retention of the Black middle class, then ministry approaches must be developed to address the felt needs of this class. The purpose of this study was to recommend strategies, informed 
sociological factors, theoretical frameworks, and theological implications of class and ethnicity to effectively minister to the Black middle class.

\section{Method}

Demographic data were reviewed to create an ethnographic profile of the Black middle class. From the profile, the felt needs of this class were derived. A survey was conducted ( $n=177$ ) to determine what specific factors influence Black middle class persons to attend or affiliate with a church. Recommendations for ministries for the Black middle class were informed by the ethnogragph, the survey, a review of theoretical approaches, and a biblical theology.

\section{Results}

The ethnogragphic data reveal that as a result of social stressors and economic and educational disparities, the Black middle class feel alienated from the societal mainstream. Survey data reveal that (1) for Black middle class "biblical teaching" was the most important factor in church affiliation; (2) "Contemporary Christian" was the preferred worship style; (3) parenting support was preferred for emphasis in the church; (4) one-on-one Bible study was the preferred form of evangelism; and (5) 73 percent of respondents reported they would consider joining a non-African American church.

\section{Conclusion}

This study identified (1) the Black middle class as a people group, (2) the felt needs of the Black middle class, (3) the desire of the Black middle class to have ministry germane to their needs, and (4) ministries for the Black middle class 
consistent with Scripture. It is concluded that if the four above realities are considered, then churches in transition will be successful in the recruitment and retention of the Black middle class. 
Andrews University

Seventh-day Adventist Theological Seminary

\title{
MINISTRY TO THE BLACK MIDDLE CLASS: STRATEGIES \\ FOR CHURCHES IN TRANSITION
}

\author{
A Dissertation \\ Presented in Partial Fulfillment \\ of the Requirements for the Degree \\ Doctor of Ministry
}

by

Dedrick L. Blue

July 2005 



\title{
MINISTRY TO THE BLACK MIDDLE CLASS: \\ STRATEGIES FOR CHURCHES IN TRANSITION
}

\author{
A dissertation \\ presented in partial fulfillment \\ of the requirements for the degree \\ Doctor of Ministry
}

by

Dedrick L. Blue
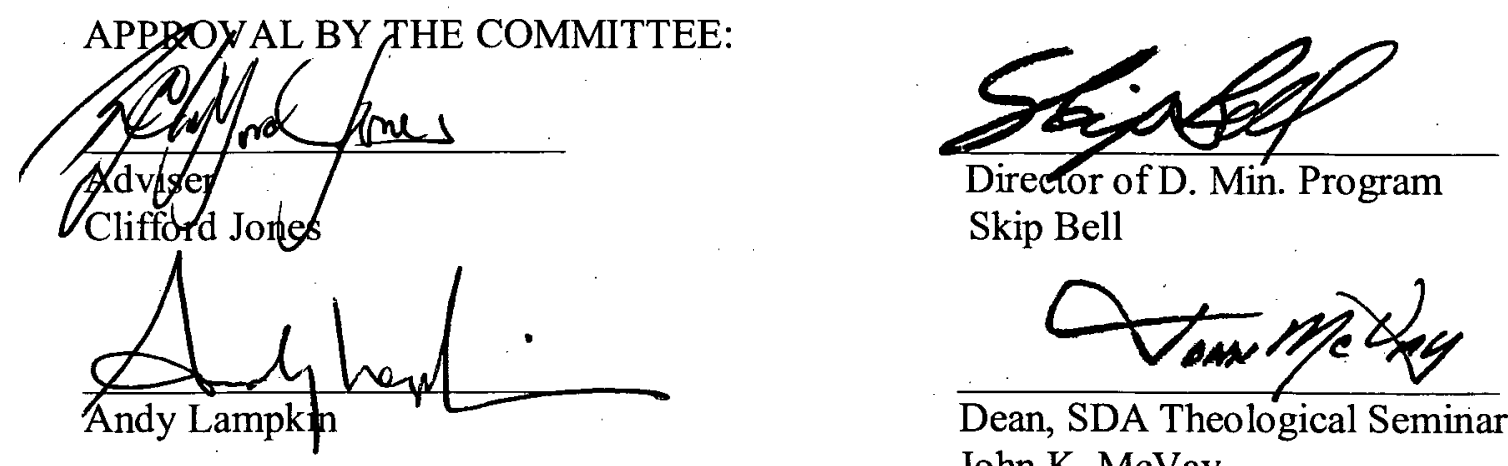

Skip Bell

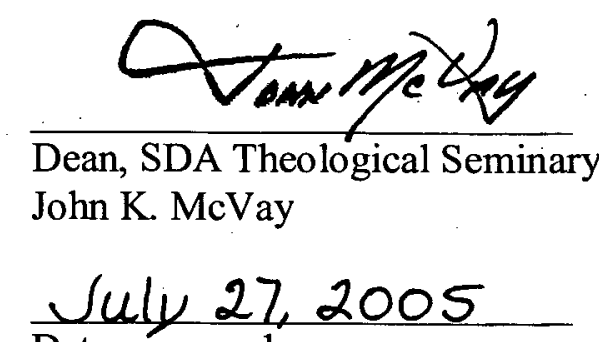

Norman K. Miles

Date approved 


\section{TABLE OF CONTENTS}

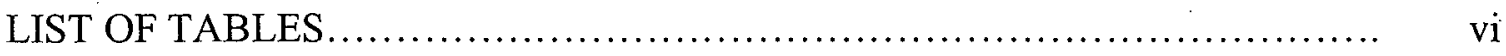

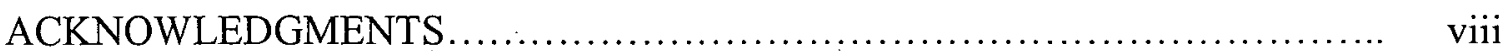

Chapter

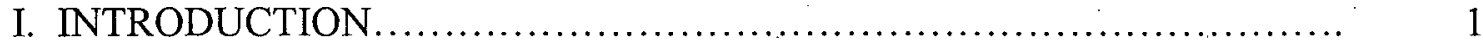

Challenges Facing Black and White Churches: Classism and

Segregation...................................................... 3

Challenges Facing the Black Church in Transition: Out-Migration.......... 9

Challenges Facing the White Church in Transition: Ethno-centrism........ 14

Statement of the Problem............................................. 16

Purpose................................................................ 16

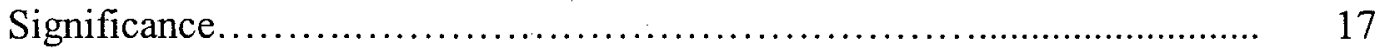

Definition of Terms......................................................... 19

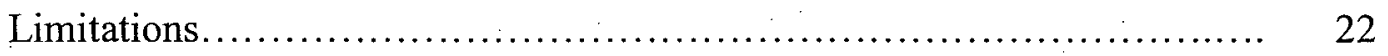

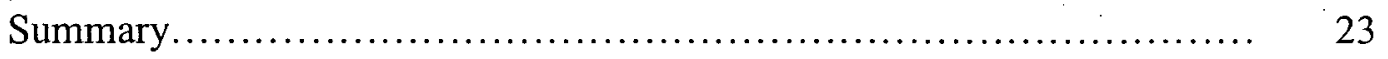

II. REVIEW OF LITERATURE....................................... 25

Historical/Sociological Description of the Black Middle Class........... 25

Relationship of Black Persons to the Church......................... 29

Diversity and Racial Reconciliation.................................... 34

Summary .................................................... 36

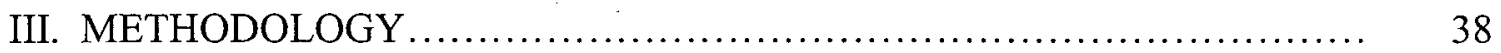

Research Methodology............................................ 38

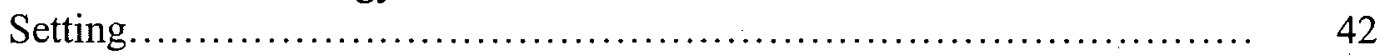

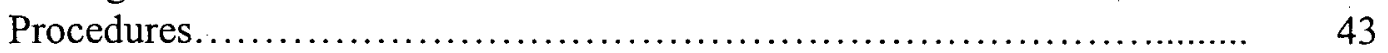

Participant Criteria.............................................. 43

Ethical Consideration for Human Subjects................................. 43

Data Collection................................................. 44

Survey Construction.................................................. 45

Survey Demographics........................................... 49

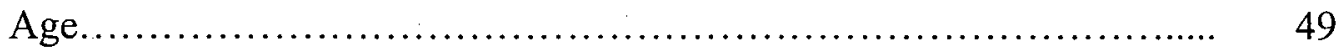


Education............................................................ 49

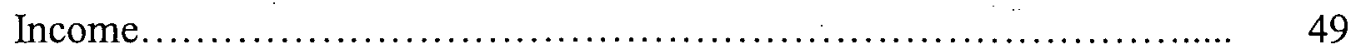

Marital Status...................................................... 51

Home Ownership and Location.................................... 51

Employment Status and Type ........................................ 52

Church Membership and Attendance................................. 52

Denominational Affiliation/Preference..................................... 54

Summary................................................................ 54

IV. THE RISE OF THE BLACK MIDDLE CLASS: DEMOGRAPHIC TRENDS AND ETHNOGRAPHIC PROFILE ................................ 55

Demographic Trends of the Black Middle Class........................... . 57

Black Middle Class Income and Key Economic Factors................. $\quad 60$

The Achievement Gap............................................ 63

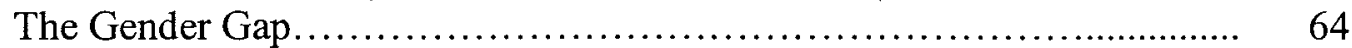

The Rage of the Privileged Class.......................................... 66

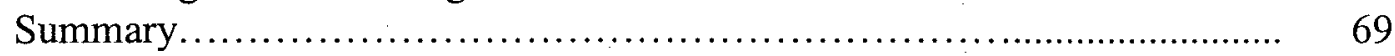

V. RESULTS OF SURVEY OF ATTITUDES, VALUES AND PRIORITIES OF THE BLACK MIDDLE CLASS IN SELECTION OF CHURCH.................................................... $\quad 70$

Results............................................................. $\quad 70$

Factors Influencing Decisions to Join a Church.............................. $\quad 71$

Willingness to Join a Non-African American Church................... $\quad 72$

Style of Worship ................................................ $\quad 72$

Desired Emphases in the Church...................................... 73

Emphasis by Education........................................... $\quad 75$

Preferred Forms of Evangelism.......................................... $\quad 77$

Most Important Worship Elements................................. $\quad 78$

The Role of the Pastor................................................ $\quad 78$

Responses to Survey and Church Growth Principles....................... $\quad 79$

VI. THEORETICAL FRAMEWORKS THAT INFORM APPROACHES TO THE BLACK MIDDLE CLASS............................. 81

Social Theory and the Study of the Black Middle Class.................... 82

Missions Theory Applied to the Study of the Black Middle Class............ $\quad 84$

Homogeneity versus Heterogeneity: Church Growth Principles............... $\quad 90$

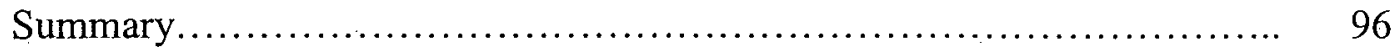

VII. THEOLOGICAL IMPLICATIONS OF CLASS AND ETHNICITY UPON MINISTRY TO THE BLACK MIDDLE CLASS ......................... 98

Status and Class in the Book of Acts................................. 98 
Class in the Epistle of James....................................... 107

Sin of Lust........................................................ 110

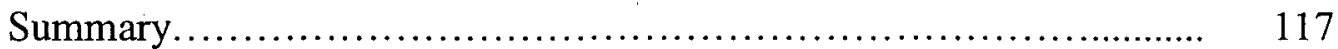

Ellen White's Statements on Class..................................... 118

Summary.............................................................. 122

Oneness: A Biblical Mandate.................................................. 123

Relationships Between Philology and Theology: Linguistic Distortion of the Biblical Mandate.............................................................. 126

Oneness: Transcending Culture........................................ 129

Summary................................................................... 133

VIII. DISCUSSION: MINISTRY AND PRAXIS STRATGIES................. 135

Worship and the Black Middle Class................................. 136

The Role of Music...................................................... 137

The Role of Preaching ............................................ 138

Programs........................................................... 143

Personal Finance................................................ 143

African-American Health.................................................... 145

Marriage Enrichment............................................... $\quad 145$

Career Development................................................... 147

Educational Enrichment.......................................... 148

Pastoral Care......................................................... 150

The Pastor as Prophet. $\quad$......................................... $\quad 150$

The Pastor as Priest................................................. 153

The Pastor as Evangelist.......................................... 156

The Pastor as a Facilitator of Ministry: Pointing to Christ..................... 159

IX. SUMMARY, RECOMMENDATIONS, AND CONCLUSIONS.............. 163

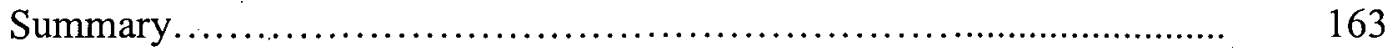

Recommendations for Further Study ................................ 165

Conclusions........................................................ 167

APPENDIX: SURVEY OF MIDDLE CLASS AFRICAN-AMERICANS'

ATTITUDES TOWARD CHURCH............................ 170

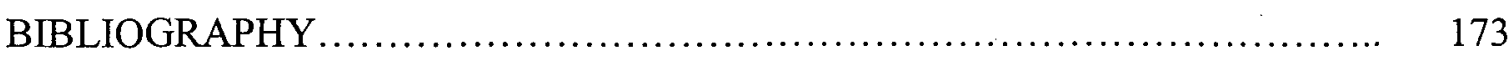

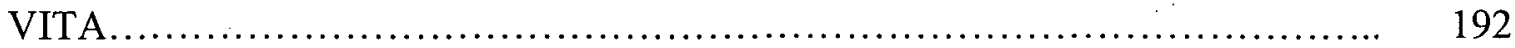




\section{LIST OF TABLES}

1. Terminology Comparison: Barna/Jackson and Schwarz.................. 48

2. Demographics: Gender, Age, Education and Income..................... 50

3. Demographics: Marital Status.............................................................. 51

4. Demographics: Household, Homeownership, Home Location............. 52

5. Demographics: Employment Status and Type........................... 53

6. Demographics: Church Membership and Attendance...................... 53

7. Denominational Affiliation/Preference............................... 54

8. Median Incomes and Earning Percentages for Blacks and Whites in Select US Cities................................................... 60

9. Factors That Impact Decisions to Join a Church......................... 71

10. Joina Non-African-American Church? ........................... 72

11. Style of Worship..................................................... 73

12. Desired Emphases in the Church................................... 74

13. Education by Selected Emphases............................................... 76

14. Most Effective Forms of Evangelism.............................. 77

15. Most Important Worship Elements.................................. 78

16. Role of the Pastor....................................................... 79

17. Barna/Jackson and Schwarz Compared: Selected Factors That Influence Church Affiliation....................................... 80 
18. Literary Comparison in the Epistle of James: Wealth and Lust versus Christ............................................................ 111

19. Ultimate Needs Met in Christ........................................ 162 


\section{ACKNOWLEDGMENTS}

I wish to acknowledge the assistance received from (1) my advisers: Dr. Clifford Jones, Dr. Andy Lampkin, and Dr. Norman Miles; (2) my friends and colleagues: Ms. Gwen Baker, Dr. Gregory Allen, Dr. Carol Allen, Dr. Howard Weems, Dr. Stephanie Weems, Elder Stennett Brooks; and (3) my family: my mother, Ruth Blue, and my sister, Lorena Oliver, for their continual prayer and unflinching support; my brother, Roderick Blue; my late father, William Blue; my late grandparents, Curtis and Lillian Wrenn; my great-grandfather, the late Reverend J.R. Nelson; my most wonderful children, Fredrick, Cedrick, and Anitria; and most especially my wife of 23 years, Dr. Elfreda Blue, without whose encouragement and support this project would not have been possible. But, indeed, all honor and praises be to my Lord and Savior, Jesus Christ, who has blessed me exceedingly, abundantly, above all that I could think or ask. 


\section{CHAPTER I}

\section{INTRODUCTION}

The United States is undergoing a major demographic shift. Between 1997 and 1998, over one million Black people in the United States rose from poverty to middle class status. ${ }^{1}$ The percentage of Blacks living below the poverty line fell to $26.1 .^{2}$ Although the number of Blacks in poverty is still disproportionately high, the trend reveals the emergence of a new more stable Black middle class. Hill notes, "Middle class Black families had one of largest increases (greater than 86 percent) over the past two decades."3

Demographers are also noting a general decline in the number of White births per thousand. In 1990 Whites comprised 80 percent of the population. ${ }^{4}$ By 2000 , the White population decreased to 72 percent and is expected to be only 68 percent by 2010 , and approximately 50 percent by $2050 .^{5}$ With the rate of births among Blacks and Hispanics

1 Louis Uchitelle, "Rising Incomes Lift 1.1 Million Out of Poverty)" New York Times on the Web, 1 October 1999. www.courses.psu.edu/hd fs/hd fs 597 rxj9/census-income.htm (accessed 19 February 2005).

${ }^{2}$ Ibid.

${ }^{3}$ Robert B. Hill, The Strengths of the African American Family: Twenty Five Years Later (Lanham, MD: University Press of America, 1999), 76.

${ }^{4}$ George Barna and Mark Hatch, Boiling Point: How Coming Cultural Shifts Will Change Your Life (Ventura, CA: Regal, 2001), 33.

${ }^{5}$ Ibid. 
increasing, by the year 2020 , the so-called minority populations will collectively become the majority population in the United States.

Black people now live in the post-civil rights era. Segregation has given way to integration. Pervasive and persistent poverty amongst Black people has given rise to pockets of prosperity. Illiteracy has given way to educational opportunity. The Black people of today are different from those of past generations. The "talented tenth," as Dubois termed educated and upwardly mobile Blacks, now has become the talented third as more Blacks move into the ranks of the middle class. Today's middle class Blacks are a hybrid of sorts, possessing, in part, the wealth of their White counterparts while remaining connected to their Black roots. They are bicultural enough to work in the White world five days a week and to worship in Black churches on the weekend.

As we move into a new millennium, there are new challenges facing Black people and new dynamics impacting the next phase of ecclesiastical formation. The end of racial segregation and the increased economic and educational upward mobility for Blacks have brought many challenges to the Christian church. Middle class Blacks, those who exceed the poverty threshold with incomes up to $\$ 100,000$, are moving into close proximity to predominantly White Seventh-day Adventist (SDA) churches. Because of the increased number of Black middle class persons in Black congregations that have been traditionally poor, class tensions have begun to arise in the church. Simultaneously, the out-migration of the Black middle class to suburbia has created both the fear of abandonment in Black congregations and resentment in anticipation of abandonment. Pastors are overwhelmed; churches are confused and Black middle class persons are lost. 
These trends present several challenges for the church. How will this change the church? Will class tensions emerge and evolve in the church as it faces this new economic diversity? What will be the impact upon church governance? How will the emergence of the Black middle class affect styles of worship, methods of evangelism, programmatic thrusts, and community outreach? Will class flight occur as the new Black middle class leaves its traditional urban Black churches and forms new congregations that more closely reflect its sociological and economic values?

What are the implications for race relations within the church as the result of the rise of the Black middle class? Will Black middle class people, seeing that they have much in common with their White counterparts, now choose to cross the color line and affiliate with predominantly White congregations that are in closer proximity to their new homes? What should White churches do in preparation to receive Black middle class persons? How will the pastor relate to the major and unprecedented sociological shifts? What new church ministries will be needed to address this newly emerged Black middle class? What role will the preacher have in the formation of new ministries to the Black middle class?

\section{Challenges Facing Black and White Churches: Classism and Segregation}

There are two challenges facing both Black and White churches in this era of transition. "Classism" is also known as class consciousness or an awareness of belonging to a class in the social order with definite economic interest creating a sense of class 
solidarity. ${ }^{1}$ The second major challenge is the historical pattern of ethnic segregation. A brief discussion follows.

In Black and White churches alike there may be the tendency to ascribe morality to wealth and poverty. Churches in economic transition must be continually on guard not to be self-congratulatory of their perceived economic success and attribute that success to their own moral goodness, or personal righteousness. Society has ascribed moral goodness to wealth, and moral failings to poverty.

We live in a society that often measures success by the amount of assets that one has amassed. The ethic of capitalism lauds those who have been able to navigate the economy and come out winners. Indeed, we have developed an entire vocabulary to describe those who have done so: "those who made it," "hard working," "shrewd investor," "contributor to society," "true American." We ascribe the nobler virtues to the wealthy, even if the means by which they obtained that wealth were less than noble. The Kennedys, of political fame, made a fortune from selling illegal liquor during Prohibition. Many well-to-do families gathered wealth from exploitation of workers, manipulation of markets, political patronage, and even criminal activity. Yet, one generation removed, their history has been reframed to cast them as the true embodiment of American tenacity and ingenuity. They have become modern-day Horatio Algers, having pulled themselves up by their own bootstraps. They are viewed as prime examples of the Protestant work ethic: that work is a blessing from God and that those who work hard will be blessed by God. Financial blessings have been equated with spiritual blessings and are seen as an indicator of character.

\footnotetext{
${ }^{1}$ Webster's New World Dictionary of the American Language, $2^{\text {nd }}$ Collegiate edition (1982), s.v. "classism."
} 
Just as we have vocabulary to describe the wealthy, we also have one to describe the poor: "lazy," "irresponsible," "free loader," "welfare queens." Poverty is seen as either a curse from God on those who are not obedient to His will, or the result of a character flaw in the individual. It is reasoned that if only a person were more faithful to God, harder working, thriftier, intelligent, savvy, or more diligent in his or her affairs, then he or she would not be poor. The propagators of the gospel of prosperity, with their books, and tapes, and DVDs, have convinced many that wealth is theirs for the asking: that all they have to do is "name it and claim it." 1 Little consideration is given to the fact that there are many reasons for poverty and not all are the results of individual character flaws. Some poverty is also the result of the greed of the wealthy, the apathy of the fortunate, the ignorance of the good, the circumstances of birth, and the consequences of life. There are the working poor, who although industrious do not receive the same remuneration for their labor. Among the poor are the widowed, those made poor through illness, some elderly, those who have lost wealth due to bad investments, the disabled, and single-parent or single-income families with dependent children. ${ }^{2}$ There are many reasons for poverty, many of which have nothing to do either with the integrity of the person, or the retribution of God.

\footnotetext{
'The so-called "Word of Faith Movement" founded by E.W. Kenyon involves the doctrines of correct thinking and believing accompanied by positive confession. Word-Faith teachers claim that God is bound by spiritual laws and is bound to obey the faith-filled commands and desires of true believers. Major propagators of this doctrine include Kenneth Hagin, Kenneth Copeland, Frederick K.C. Price, Paul Crouch, Benny Hinn, and Paul Yonggi Cho. For further discussion see Hank Hanegraff, "What's Wrong With The Faith Movement (Part One): E.W. Kenyon and the Twelve Apostles of Another Gospel" (Santa Margarita, CA: Christian Research Institute). Available at www.equip.org/free/DC755-1.htm (Accessed 30 April 2005), Statement DC755-1.

2 Ronald J. Sider, Just Generosity: A New Vision for Overcoming Poverty (Grand Rapids: Baker Books, 1999), 181, 185.
} 
The challenge to the church, both Black and White, is not to ascribe morality to income or class. Mercer writes:

Classism in the church is a very real challenge to the authentic message of the gospel. Unfortunately, the church is sometimes confused about the importance of class. This is evidenced by a tendency of some to equate spiritual maturity with financial success and others who make the automatic assumption that if a person has great wealth he has compromised his commitment to Christ. ${ }^{1}$

A person is not inherently more or less spiritual based upon status or class. The way in which a person relates to class or status may be reflective one's Christian maturity. But, says Mercer, "our spirituality is not defined by social class or cultural background." ${ }^{2}$ Because class and culture seem to be such defining factors in our society, it is difficult not to allow the same thinking to creep into the church. "Unfortunately, for some believers their class is not only a reference to their economic status, it is a mark of how they evaluate their personal significance. It forms the basis for how they evaluate all their professional and spiritual relationships."

The second challenge facing both the White and Blackchurch is overcoming historical patterns of ethnic congregational groupings. It has been rightly said that the most segregated place on Sunday or Sabbath morning is the church. In America, there is a long history of racial and class division when it comes to worship. Niebuhr observes, "The existence of the racial schism in America is one of the clearest facts in the whole mixed pattern of American denominationalism." ${ }^{, 4}$ The traditionally Black denomination,

\footnotetext{
'Larry Mercer, "Dismantling Class Barriers: Can the Church Avoid Wealth-based Prejudice?" In Building Unity in the Church of the New Millennium, ed. Dwight Perry (Chicago: Moody Press, 2002), 143.

${ }^{2}$ Ibid.

${ }^{3}$ Ibid., 142.

${ }^{4}$ H. Richard Niehbur, The Social Sources of Denominationalism (New York: New American Library, 1975), 239.
} 
the African Methodist Episcopal, was born when Richard Allen, Absalom Jones and other Black worshipers were "pulled from their knees during worship" at the St. George Methodist Church in Philadelphia in 1787. ${ }^{1}$ This is rather unfortunate since the Methodist Church was one of the most open to accepting Negroes and had been the most proactive in the evangelism of Blacks.

The Black Baptist denominations such as the National Baptists Convention, USA; the National Baptist Convention of America; and the Progressive National Baptist Convention, are separate from the predominantly White Baptist Associations including the American Baptist and the Southern Baptist. It appears that ethnic from ethnic tensions and ethnic division are a part of the American ecclesiastical landscape. But the American church has not only been divided along the line of race but also of class. The Lutheran Church, the Presbyterian Church, and the Episcopal Church tend to be the choice of the upper classes. Patterns of association for worship and fellowship along race and class lines are long established. ${ }^{2}$

The Seventh-day Adventist Church in North America is structured along ethnic lines. Regional conferences are predominantly African-American with AfricanAmerican administration, ${ }^{3}$ whereas state conferences are predominantly Anglo with corresponding leadership. Often Seventh-day Adventist churches exist within the same

1 C. Eric Lincoln and Lawrence H. Mamiya, The Black Church in the African American Experience (Durham, NC: Duke University Press, 1990), 50, 51.

${ }^{2}$ Niehbur, 125.

${ }^{3}$ There are nine "regional conferences" in the North American Division of Seventh-day Adventists. Each regional conference administers African American churches spanning a territory of several states, hence the name regional. The first, The Lake Region Conference, was formed in 1944 after a decade of rising racial tensions in the church. For a more thorough history of the development of the 
city, and yet because of the cultural and structural divide, there is little if any fellowship. One city, located in the Northeastern United States, had only five Seventh-day Adventist churches, with four pastors, and yet the two pastors of the regional conference did not know the two pastors of the state conference and vise versa. This racial divide has created long-established patterns for where people worship and how they worship.

In this same town, a Black family visiting the state conference church, without solicitation, was directed to the regional church on the Black side of town. This has not been an uncommon occurrence. I know many such incidents that could be shared.

Without casting blame, one can simply state that the redirection of Blacks to the regional church could be rationalized as a reasonable course of action. One could reason that the regional churches were officially created by the Seventh-day Adventist Church to cater to the particular needs of Blacks, that a Black person feels more comfortable with people more familiar with his or her own culture. It is probable that based on such rationalizations the redirection of the Black worshippers to the regional church took place.

Now, with the emergence of the new Black middle class and their move into the suburbs, White members are being asked to alter the long-established pattern of relating to Black members in the church. They are asked to do something that is counter-intuitive in a church that has been divided along the lines of race. This is further complicated by the fact that the regional conferences are thriving. The sanction of the church for ethnic division has left many feeling justified in protecting the homogeneity of their White or Black congregation. 


\section{Challenges Facing the Black Church in Transition: Out-Migration}

When one speaks of the Black church in transition as it relates to class, one must keep in mind that there are two Black churches experiencing transition. First, there is the newly formed Black suburban church that has moved away from its traditional urban and diverse class roots to form more homogenous congregations. Second, there is the traditional Black urban church that has served persons of varying socioeconomic status that is now experiencing either class tension between the middle class and lower class, or class drain as its economically stable middle class parishioners are being siphoned off to the suburbs.

A key component in the viability of the Black community has been the Black church. "The African American Church is the institution that traditionally, has provided the Black community with a base for spiritual and social growth." ${ }^{\prime 1}$ Trussell traces the development of the Black urban church through the "Great Migration" northward and rehearses the role of the Black church in the social, political and economic uplift of Black people. But, she also notes the growing trend of Black middle class suburbanization, and the trend to start new congregations far away from their traditional urban roots. ${ }^{2}$ Hudson searches for explanation, "Now, a growing Black middle class and the lack of available land in the cities are luring some African American congregations to suburbia as well."3 Where are the Black middle class attending church in suburbia? Harris described the

\footnotetext{
1 Jacqueline Trussell, "The Changing Face of Religion: The Suburbanization of the Black Church," Black and Christian.com (20 January 2005), 3.

${ }^{2}$ Ibid.

${ }^{3}$ Kelly Hudson, "Inner City Churches on the Move," Religion and Ethics Newsweekly, February 6, 2004, 5-12.
} 
development of the Black middle class mega-church. He writes, "Some of the biggest are in sprawling suburban areas where upwardly mobile Blacks have moved."1

One example of a mega-church is the Bethel AME Church cited by Barna and Jackson. Bethel, one of the oldest continuous congregations in the United States, helped give birth to the African Methodist Episcopal Church in 1816. By the 1850s, the church had grown to a membership of 1,500 and had become a center advocacy for abolition and education. Today, the church boasts a membership of 14,500 with a weekly attendance of $4,000 .^{2}$ By sheer size alone it ranks as a formidable mega-church. The church has spawned a number of ministries that have had a profound impact upon the surrounding urban community. However, with its exponential growth has come a desire to expand the church complex. At the time of the publication of Barna and Jackson's book (2004), the church was in the process of acquiring 256 acres of land in western Baltimore County, where 50 percent of its membership currently resides. ${ }^{3}$ Trussell asks:

As middle class Blacks migrate to communities outside of urban environments, where do they go for spiritual development? How is religion in urban America shifting and changing in the light of the out migration of non-poor Black families? Will urban church membership experience a decline in response to this movement? ${ }^{4}$

Hudson observes that the success of the suburban mega-church is leaving a void in the neediest neighborhoods. McRoberts remarks, "Historically, Black religious

${ }^{1}$ Hamil Harris, "Growing in Glory," Emerge, April 1977, 49-53.

${ }^{2}$ George Barna and Harry R. Jackson, Jr., High Impact African American Churches: Leadership Concepts from Today's Most Effective Churches (Ventura, CA: Regal Books, 2004), 204-205.

${ }^{3}$ Ibid., 205.

${ }^{4}$ Trussell, 3. 
institutions have had to play the role of the house builder, the bank-all kinds of roles. And neighborhoods where Black churches have been present, of course, when time comes for the church to leave, could present a crisis for that neighborhood."1

Churches have had a moderating influence on drugs and other illegal activity. Churches have provided numerous programs for the support of young families, educational and cultural enrichment for children, job readiness and career networking for those entering into the job market.

So there is a two-fold challenge facing the Black church because of the outmigration of the Black middle class. First, there is the challenge of distancing. The move to suburbia has expanded the church facilities and brought the church closer to where its new emerging middle class resides; yet it has left a gaping hole in some of the urban communities that gave the church birth. The Black church has been the place where persons of all classes could come and worship together. This coming together for worship brought Black people of various social classes into the worlds of each other. Those in the higher classes were reminded of their obligation to the less fortunate, while the lower social classes saw a model of upward mobility to which they could aspire. The physical removal of the church to suburbia decreases the likelihood that people from different social classes will share a common experience and interact in a meaningful way. The consequence of this distancing may be the impoverishment of all classes. The bond formed between the classes in the urban church may be fractured as churches relocate, because the previously intimate social intercourse is disrupted.

\footnotetext{
'Hudson, 7.
} 
The distancing on the part of the middle class creates the challenge for the Black church, the isolation of the poor. Those left behind are increasingly isolated and ghettoized into pockets of hopelessness. How the Black church in transition chooses to respond to its historic mission of raising the disenfranchised will be a major challenge in the future.

The problem of class within the Black church is a serious problem for the Black pastor. If the preacher is fortunate enough to have a multi-class congregation, then he or she may soon discover some of the subtle class conflicts in the church. In the church, spiritual gifts should be that which recommends one for service. However, even though the church is God's appointed agency, it is still plagued by and populated by fallen human beings who may value educational attainments over the spiritual graces and financial wealth over spiritual wealth. And so, when it comes to having influence, position, and power in the church, the "haves" have and the "have-nots" have not. Because the physician is valued in society, then he/she is correspondingly honored in the church and therefore may be more likely to rise to church leadership than a street sweeper. That there is classism in the church is without question. Doctors, lawyers, and professionals become elders, while plumbers and carpenters are deacons.

This breeds class tension within the church. Often those who are not in power will speak negatively about "those elders and the pastor who think that the rest of us are dumb." At the time to nominate or elect officers to the church one might hear, "Well they would never elect me to that office. After all I don't have a degree." Or one might hear, "These people don't even live in this neighborhood are coming down here trying to tell us what to do." 
Now the professional may not have necessarily done anything worthy of receiving such hostility. In truth, they may be simply doing what they are asked to do. They may bring a skill set to the table from their education or employment that actually facilitates the task. They reason, "I do this all day long for the job; I ought to be able to do this for my God and my church." And so, they cannot understand the hostility they receive when they accept an office or chair a meeting. And being human themselves, they may defend themselves by smugly reminding their attackers, "Well, I was trained to do this."

There are times when the Black middle class person may come seem arrogant or snobbish. Having left poverty behind, they disdain it, but that disdain for the condition of poverty may be mistaken for disdain of the poor. McMickle asserts:

The challenges presented by race and class must be addressed within the Black community, and especially with and among Black churches. This must take place in the inner-city churches where encounters between Black poverty and Black prosperity are repeated every week. It needs also to take place in the Black and White suburban churches where many in the Black middle class have gone, perhaps to escape the sights, sounds and smells of poverty. ${ }^{1}$

Unfortunately, the Black pastor may fall into the trap of esteeming class above piety or spiritual giftedness. If the church is poor, or small, or urban, the pastor may need the financial stability that a physician brings to the table. If the pastor is visionary and perceives that his congregation by lack of exposure is not visionary, then the pastor will highly value and greatly esteem having an educated person with whom he or she may share his or her vision. The pastor can never forget that the church is both a religious organization and a political one and that the politics of keeping the affluent involved and engaged may be perceived as class favoritism and cost him other politically with the poor.

${ }^{1}$ Marvin McMickle, Preaching to the Black Middle Class: Words of Challenge, Words of Hope, (Valley Forge, PA: Judson Press, 2000), 14. 


\section{Challenges Facing the White Church in Transition: Ethno-centrism}

The challenges facing the Whites church are different. There are three major challenges: (1) acceptance of a new reality, (2) interpreting the changing social landscape, and (3) understanding the history that has given rise to Black apprehension and fear. Each of these may influence the ministry of White congregations to the Black middle class.

First, the White church is challenged to accept a new reality. Most mainline Protestant churches have long since abandoned the inner city. White flight to the suburbs brought with it the relocation of churches. This is an historical phenomenon of some forty years. The very persons from whom the church fled are now next-door neighbors. The Black middle class, once excluded from previously primarily White communities by legal sanctions and financial constraints, now have the right and the means to choose where they will reside. The church could move again, but with the increased mobility in our society and the increased upward mobility of the Black middle class, the White church now has nowhere to which it may retreat. The White church must accept the fact that Black persons will be present in its congregations.

The second challenge facing the White church in transition is one of interpreting the changing landscape of diversity, and properly framing the issues to be explored en route to oneness with the emerging Black middle class. Part of the challenge will be to expose the philosophical and theological presuppositions on race and how they have helped to shape a divided Christian church. Also, the White church must begin to recognize how it has been influenced by the larger society on the issues of race and class. 
It is possible for the church to have the illusion of koinonia (fellowship) because it has a few ethnic members in the pews. But, if those members perceive that they are simply tolerated and not accepted, then true Christian fellowship has not occurred. This may create a false sense of oneness.

The third challenge for the White church in this era of transition is to understand the history that has given rise to Black apprehension and fear. Persons come to be who they are as a result of the experiences that shaped them. The same is true for a people. The modern state of Israel is one of the most militaristic nations on earth; but its militarism must be seen in the light of the Holocaust and the hostility of its neighbors. Northern Irish resistance is the product of English dominance. Catholics' fear of political marginalization in America is the result of years of Protestant anti-Catholic dominance of politics. Likewise, Black fear and misapprehension are the result of centuries of racial hostilities, misunderstandings, stereotyping, and exclusions. If the church is to recruit the Black middle class, then it must be cognizant of Black history: how Blacks came to be, not just how they came to be in the new neighborhood. How Blacks came to be tells the White church who Blacks are. Who they are tells the White church how they feel and perceive the world around them. That, in turn, tells the White church how to approach Blacks. But to invalidate a person's past is, in essence, to ignore the person himself. Because we now live in an era of equal rights and opportunity, some might say that to hold on to the idea of the existence of racism is to perpetuate it. The fact that there are now middle class Blacks living in the suburbs may be seen as proof that racism is over. But, to the Black middle class person who has battled racism his or her entire life, a statement by Whites that racism is over may be seen as evidence of its continued 
existence. The feeling evoked may be, "If they invalidate my struggle, then perhaps they are invalidating me." The church must be as intentional in healing the wounds of racism.

Clarence Shuler reminds us that the history of African Americans is in fact

American history that must be embraced if racial reconciliation is to occur:

If you are White and you want to "reconcile" with your Black Christian brother or sister, you must understand that this history is the heritage (good and bad) he or she will bring into the relationship. The issue is not that you necessarily agree with the interpretation or the perspective of that history, but that you at least try to understand it. ${ }^{1}$

To summarize, the challenges facing the church are many and complex. First if the church would win the Black middle class, then it must grapple with how the church thinks about class, and the historical patterns of social interaction between Blacks and Whites.

\section{Statement of the Problem}

The major demographic shift of Blacks into the middle class has created challenges for churches seeking to recruit and to retain this population. If churches are to be successful in the recruitment and retention of the Black middle class, then ministry approaches must be developed to address the felt needs of this class.

\section{Purpose}

The purpose of this study is to (1) discover sociological factors, (2) explore theoretical frameworks for ministry, and (3) examine the theological implications of class and ethnicity which may inform ministry to the Black middle class in churches in transition.

\footnotetext{
' Clarence Shuler, Winning the Race to Unity: Is Racial Reconciliation Really Working? (Chicago: Moody Press, 1998), 91.
} 
Sociological factors include both the forces in society which have helped to shape and given rise to the Black middle class and the self-identified factors which influence the Black middle class to attend to affiliate with a church. Theoretical frameworks are a speculative idea or plan as to how things might be done based upon systematic statements or principles. ${ }^{1}$ Theological implications are doctrines arising from the study of the Bible which directly inform mission and praxis in this study.

\section{Significance}

The findings of this proposed research will be used to inform the development of relevant approaches and church ministries to the Black middle class. The findings of this study will prove useful to several constituencies.

First, this study will be helpful to the pastors and congregational leaders who are experiencing demographic shifts in their congregations. Black pastors will find strategies to retain their middle class members and White pastors will find strategies to recruit the Black middle class moving into their neighborhood.

Second, this study will be useful to church leaders and church planters. The ethnographic profile of the Black middle class and the survey results from the Black middle class may be used to inform evangelism and church-planting decisions. This study may assist church leaders in decisions of employment and assignment of pastors to particular districts in social transition.

Third, this study will be of interest to social scientists, particularly in the fields of sociology and religion. Sociologists will take note that this study identifies AfricanAmericans as a unique people group. They will note that the study based in social

\footnotetext{
'Webster's New World Dictionary of the American Language, s.v. "theory."
} 
description compares and contrasts the Black middle class and the White middle class. Also, the study brings to light the unique economic, educational and social challenges faced by the Black middle class. Social scientists will see how the social history of the United States has impacted the patterns of social interaction and has shaped the Black middle class into a unique group, distinct from its White counterpart. The religionist will note the shifting dynamics in both the White and Black church in America and will see how culture, history, and race must be taken into consideration if the church would remain a viable and vibrant force in the life of the Black middle class person.

Fourth, researchers will note that this study adds to the body of literature on the subject. Very little is written on the subject of the Black middle class. Observations of this class are usually found buried in larger studies on ethnicity. Even less is written on the Black middle class within the context of church. This research is necessary to code observations, to develop constructs and hypotheses and to record the authentic unmediated voice of the Black middle class.

Fifth, the findings will be useful to the larger Black church community. The survey conducted of the Black middle class persons of their attitudes, beliefs, values and preferences in regard to church affiliation and attendance will be inclusive of various denominations.

Sixth, I am an educator and an administrator at a Seventh-day Adventist institution of higher education. The information in this study may inform curriculum development. 


\section{Definition of Terms}

Church: A single body of Christian believers who worship, fellowship, and practice Christian ministry within a specific local geographical context.

The Church: Term used to describe all Christian believers. When speaking of a particular sect or denomination, the proper name shall be given, for example, "Seventhday Adventist (SDA) Church," or simply "the church" if the context has specified a denomination.

Churches in transition: Bodies of Christian believers experiencing a changing dynamic in or around the church. The transition may represent both institutional and contextual factors. ${ }^{1}$ C. Kirk Hadaway's categories describe certain types of churches that are in transition and imply the contextual factors, although not explicitly stated. ${ }^{2}$ However, this study uses the term to describe a variety of internal and external factors that impact the church:

1. Changes in the demographic composition of the church. This may include class, ethnicity, any socio-economic factors, and thinking patterns, attitudes, beliefs, perceptions and myths.

2. Changes in the physical location of the church being examined. For example, a church may relocated from an urban environment to a suburban one.

' C. Kirk Hadaway, "Learning from Urban Research," in Planting and Growing Urban Churches: From Dream to Reality, ed. Harvie M. Conn (Grand Rapids, MI: Baker Books, 1997), 41.

${ }^{2}$ The categories delineated by Hadaway describe five types of growing churches in racial transition: (1) ethnic churches composed of 85 percent minority, (2) multiple mission churches in which a mother church (usually Anglo) shares its facilities with one or more ethnic missions, (3) multiethnic churches composed of mostly Anglos, Hispanics and Asians, (4) regional churches usually located on the edge of the city and draw from suburban and exurban territories, and (5) satellite formed in the suburbs by urban churches that is able to attract an Anglo clientele to an increasingly minority mother church. 
3. Changes in the external environment of the church, whether those factors are political, denominational, economic, geographical, sociological, and or any external factor that may force change upon the church.

4. Changes in the internal structure and operations of the church. This may include a change of, or a realignment of, internal systems, subsystems, policies, procedures, protocols, and/or practices.

5. Changes in ministerial praxis including program outreach and in-reach activities.

Class: A group of people considered as a unit according to economic, occupational, or social status; especially. a social rank or caste. ${ }^{1}$ The notion of class is elusive in the American context. According to Fussell, "Class distinctions in America are so complicated and subtle that most foreign visitors often miss the nuances and sometimes even the existence of class structure."2 Some would describe class based exclusively on income. Others would include attitudes, values, education or race as major determinants of class. Fussell writes:

At the bottom, people tend to believe that class is defined by the amount of money you have. In the middle, people grant that money has something to do with it, but think education and the kind of work you do is almost equally important. Nearer the top, people perceive taste, values, ideas, style, and behavior are indisputable criteria of class, regardless of money or occupation, or education. ${ }^{3}$

Most sociological definitions of "middle class" follow those first described by nineteenth century sociologist Max Webber. "Here the middle class is defined by a

\footnotetext{
'Webster's New World Dictionary of the American Language, s.v. "class."

${ }^{2}$ Paul Fussell, Class: A Guide through the American Status System (New York: Touchstone, Simon and Schuster, 1983), 16.

${ }^{3}$ Ibid.
} 
similar income level as semi-professionals, or business owners, by a shared common culture of domesticity and sub-urbanity, and, by a level of relative security against social crises in the form of socially desired skill or wealth."1 Webber's original definition may be somewhat dated in that today's middle class may be professional or semi-professional, a business owners or laborers, urban or suburban, may share income level more than culture, and do not consider themselves relatively secure against social crises.

Middle class: This study will assume that those who exceed the poverty threshold, calculated by income $x$ family size earning between $\$ 19,400$ and $\$ 100,000$ are middle class. The United States Census Bureau does not have an official definition. One way to determine the economic middle class is to take the median household income and define the middle class at between 80 percent and 120 percent of the median. ${ }^{2}$ But because of regional income disparities this definition does not work very well. Another definition of the middle class is that "it has come to represent a large swath of the American populace with incomes between approximately 200 percent of the federal poverty level threshold and those of the nation's top five percent income earners roughly $\$ 25,000$ to $\$ 100,000$ a year. ${ }^{33}$

For the purpose of this paper, we shall accept the income parameters of $\$ 25,000$ to $\$ 100,000$ with one notable exception. A single person or couple sharing a household with an income of $\$ 19,400$ will be considered "middle class." Because the official United

\footnotetext{
1 "Middle Class: Sociological Debates Concerning Definition," Wikipedia, http://en.wikipedia.org/wiki/Middle_class (accessed 21 February 2005).

2"New York Families: America's Juggling Act, Who Is the Middle Class?" WSKU transcript, http://www.wsku.org/news/features/familyseries/middleclass transcript.html, April 2001 (accessed 21 February 2005).

3 "Middle-Class 2003: How Congress Voted," http://www.drummajorinstitute.org/plugin/template/dmi/27/2322 (accessed 21 February 2005).
} 
States poverty threshold is based upon a formula of income $\mathrm{x}$ family size, then this study will use a similar formulation. In 2005 , poverty is defined as $\$ 19,350$ for a family of four. ${ }^{1}$ Three thousand two hundred sixty dollars $(\$ 3,260)$ is added or subtracted per person.

Black: Persons of African ancestry, who share a common ethnicity, currently living and working in the United States whether citizens or legal aliens. Pollard defines ethnicity as follows, "Ethnicity refers to a person's personal and social, history-how and into which beliefs, values, and worldviews, one has been socialized."2 Ethnicity is defined as a "classification or affiliation" or designation of any of the basic groups or divisions of mankind or of a heterogeneous population, as distinguished by customs, characteristics, language or common history. In this study, "Black" refers to persons socialized in the American context who are of common ethnicity and share common beliefs, values, and worldviews. The terms "Black" and "African-American" are used interchangeably, because these terms are used interchangeably in the current literature.

\section{Limitations}

1. This study is not intended to be an exhaustive sociological analysis of the Black middle class. Rather it is intended to provide a survey of the challenges facing the SDA church ministry to the Black middle class.

\footnotetext{
'Department of Health and Human Services, "Annual Update of the HHS Poverty Guidelines," Federal Register 70, no 33 (February 18, 2005): 8373-8375.

${ }^{2}$ Leslie Pollard, ed., Embracing Diversity: How to Understand and Reach People of All Cultures (Hagerstown, MD: Review and Herald Publishing Association, 2000), 16.
} 
2. This study is limited to addressing sociological and cultural factors that impact the church and the Christian mission. It is not intended to address cultural or societal change.

3. This study is not an exhaustive examination of all the factors affecting churches in transition. The discussion is limited to churches experiencing demographic shifts in relation to the Black middle class.

4. This study is not intended to be an exhaustive theological treatise on ethnicity and class in the Christian church. Rather theological considerations are presented to inform praxis and mission.

5. The survey of Black middle class persons presented in this study was conducted in the Southeastern United States. The findings and strategies arising out of those findings may be applicable primarily to the region surveyed.

6. All denominational groups are not represented in the survey and therefore the strategies proposed may be more applicable to some denominations than to others.

7. This study is not intended to survey White persons or persons of color as to their readiness or willingness to receive Black middle class persons. Rather, it is intended to increase awareness, provide insights, and suggest strategies to those facing the challenge of ministering to and evangelizing the Black middle class.

\section{Summary}

As the face of the country has changed so also has the face of the Adventist Church. Once a largely White, rural, and North American church, the church has seen radical transformation due to explosive growth, technological advances, and globalism. The new North American Church reflects the trends of the society at large with the minority population growing faster in church membership than its White counterpart. 
The society from which the church draws its membership has changed, and the church must either be prepared to address the change or face possible marginalization of its influence in particular communities and with certain people groups. Caleb Rosado remarks, "The world and Adventism are going through vast and dramatic changes. Understanding the dynamics of those changes can lead to personal and Church growth."1 But beyond just personal change, the Church may grow as it becomes keener in its approaches to ministry. This is true in general, and in particular when ministry is conceived for the Black middle class.

1 Caleb Rosado, "Challenges of Change and the Church Mission," in Make Us One: Celebrating Spiritual Unity in the Midst of Cultural Diversity, Removing Barriers, Building Bridges, ed. Delbert W. Baker (Boise, ID: Pacific Press, 1995), 39. 


\section{CHAPTER II}

\section{REVIEW OF LITERATURE}

This literature review provided an overview of the research on the subject of the Black middle class and the church. Because the body of literature is not extensive, the literature review is divided into three sections: (1) historical/sociological literature describing the Black middle class, (2) literature exploring the relationship of Black persons to the church, and (3) literature on diversity and racial reconciliation.

\section{Historical/Sociological Description of the Black Middle Class}

The historical literature traces the rise of the Black middle class. Michael Fultz described a Black professional middle class, which arose in the United States between 1900 and $1930,{ }^{1}$ with the opening of educational opportunities to Blacks after Reconstruction. DuBois described Black middle class families as early as 1909, although at the time there were no well-defined constructs to provide a complete description. ${ }^{2}$ Some years later, E. Franklin Frazier identified the Black middle class as an emerging phenomenon. Frazier records his observations on the rise of the Black middle class in

\footnotetext{
${ }^{1}$ Michael Fultz, "The Morning Cometh: African American Periodicals, Education and the Black Middle Class, 1900-1930," The Journal of Negro History 80 (1995): 97.

${ }^{2}$ W.E.B. DuBois, The Negro American Family (Cambridge, MA: MIT Press, 1970).
} 
two groundbreaking studies, The Negro Family in the United States, ${ }^{I}$ and The Black Bourgeoisie. $^{2}$ These works have been foundational to the subject of the Black middle class in America because most other works on the subject of class in the Black community have looked at the underclass. ${ }^{3}$

The works of several other researchers on the Black middle class examined a number of sociological and political factors. Specifically, Murray Friedman notes "middle class rage" and the potential political power of the Black middle class during the early 1970s. He concluded that a coalition between Blacks and Whites could improve the lot of middle class persons of both ethnicities. ${ }^{4}$ One may conclude from Freidman that the Black middle class at the time was not seen as a significant political force and that political power is seen as a major factor in upward mobility. Another focus of research on Black middle class is family patterns. ${ }^{5}$ Harriett Pipes McAdoo discussed the importance of extended kin and fictive kin networks in facilitating upward mobility. ${ }^{6}$ Bart Landry and Margaret Pratt investigated the plight of Black middle class wives; they noted, in 1978, that Black middle class wives had higher employment rates because of

${ }^{1}$ E. Franklin Frazier, The Negro Family in the United States (Chicago: University of Chicago Press, 1939).

${ }^{2}$ E. Franklin Frazier, The Black Bourgeoisie (New York: Collier Books, 1957).

${ }^{3}$ A prominent study in the 1960 s associated the "Negro Family" almost exclusively with the underclass. See Daniel P. Moynahan. "The Negro Family: A Case for National Action," in The Moynahan Report and the Politics of Controversy, ed. Lee Rainwater and William L. Yancey (Cambridge, MA: MIT Press, 1967).

${ }^{4}$ Murray Friedman, Overcoming Middle Class Rage (Philadelphia, PA: Westminster Press, 1971).

5 A number of works have looked at family patterns including Richard Logan. Maternal Child Rearing Patterns and Children's Scholastic Achievement in Different Groups, http://www.eric.ed.gov/ERICWebPortal/Home (accessed February 23, 2005).

${ }^{6}$ Harriett Pipes McAdoo, "The Extended Kin Network and Socialization of Children in Upwardly Mobile Black Families," http://www.eric.ed.gov/ERICWebPortal/Home (accessed February 23, 2005). 
economic need. ${ }^{1}$ Martin Kutzman and Harold Childs investigated Black flight; they tracked and recorded the experiences of middle class Blacks in their migration. ${ }^{2}$

Andrew Billingsly classified 27 percent of the Black population as middle class in 1987. ${ }^{3}$ Most were two-income families with women earning less than men. He described them as highly educated and working in upper tier professional, managerial and technical positions. Women he noted were more numerous in professional positions than men but tend to be clustered into what he called "lower-level professions" such as elementary teachers and nurses. ${ }^{4}$ Billingsly makes a distinction between the middle class and the non-poor working class. But his distinction is not clean. He describes the non-poor working class as working in blue-collar industrial, trades, and service sector positions. ${ }^{5}$ He fails to take into consideration that many of the so-called non-poor working class are plant managers, supervisors, and foremen. He also fails to recognize that many so-called middle class managers and technical workers are not highly educated. He also does not account for socialization on class. Many of the non-poor working class and the middle class live in the same neighborhoods and thus interact with their community and one another. Thus, the work of Billingsly, while helpful in attempting to delineate the middle class, fails to recognize that class is a fluid concept.

\footnotetext{
'Bart Landry and Margaret Platt, "The Employment of Wives in Middle-Class Black Families," Journal of Marriage and Family 40, no. 4 ( November, 1978): 787-97.

${ }^{2}$ Martin T. Katzman and Harold Childs, "Black Flight: The Middle Class Black Reaction to School Integration and Metropolitan Change," Unpublished discussion paper, 1979, http://eric.ed.gov/ERICWebPortal (accessed 23 February 2005).

${ }^{3}$ Andrew Billingsly, Climbing Jacob's Ladder: The Enduring Legacy of African-American Families (New York: Simon and Schuster, 1992), 46.

${ }^{4}$ Ibid., 51.

${ }^{5}$ Ibid., 50.
} 
Two ethnographers, Mary E. Patillo-McCoy and Beverly Daniel-Tatum, have been foremost in describing the Black middle class and their experiences in predominantly White suburbs. Although the religious experience was not the chief focus of their work, they do acknowledge the role of the church in the life of their study populations. The two researchers have different findings on the role of the church in the life of the Black middle class. Each suggests a marginalization of the influence of the church in the lives of the Black middle class, but for different reasons.

Patillo (Patillo-McCoy), in a series of ethnographic studies in Chicago's Black middle class suburbs, records the experiences of Black middle class mother-son relationships in urban settings, and the social patterns of families living in a predominantly Black middle class suburb. ' In her most prominent work, Patillo examines the Groveland neighborhood. She notes the integral role of the Catholic Church in providing youth activities and educational enrichment programs. The church in Groveland is an ever-present part of the community, but social forces have diminished its influence.

Tatum, a psychologist, has written a number of ethnographies--including one that examines the adjustment anxieties of Black families living in a predominantly White suburb. $^{2}$ In her study of Sun Beach, only four of ten of the Black middle class residents attended church even though there were a number of Black and White churches within close proximity. Tatum concludes that (1) the traditional support systems provided by

${ }^{1}$ Mary E. Patillo (Mary Patillo-McCoy), author of several ethnographs including, "Sweet Mothers and Gangbangers: Managing Crime in a Black Middle Class Neighborhood," Social Forces 76 no. 3 (March 1998), and Black Picket Fences (Chicago: University of Chicago Press, 1999).

${ }^{2}$ Beverly Daniel Tatum, Assimilation Blues: Black Families in White Communities: Who Succeeds and Why? (New York: Basic Books, 1987). 
the church are now being provided from community agencies such as the YMCA, and (2) the residents of Sun Beach do not equate spirituality with church attendance.

\section{The Relationship of Black Persons to the Church}

Research mentioned here reflects the paucity of research exclusively on this topic. Only recently have scholars begun to seriously examine the emergence of the Black middle class. ${ }^{1}$ As the phenomenon of the Black middle class grows, a number of social commentators have taken note and a number of non-scholarly articles have appeared in magazines, newspapers, and the Internet.

There is a rather extensive body of literature on the Black church and the significance of the church in the life of Black Americans. However, very little is written on the subject of the Black middle class and the church. Most of the works do not account for class. The strengths and weaknesses of the literature follow.

McMickle's work, Preaching to the Black Middle Class: Words of Challenge, Words of Hope, ${ }^{2}$ is an ecclesiological study of the Black middle class. In a series of essays and sermons, the author examines the role of the Black church in ministering to the Black middle class. McMickle asks, "What are the ministry obligations and opportunities of Black middle class churches that are physically located within America's inner cities?" He explores the weekly drive-in to church phenomena of the Black middle

\footnotetext{
${ }^{1}$ Charles T. Banner-Haley, The Fruits of Integration: Black Middle Class Ideology and Culture, 1960-1990 (Jackson: University Press of Mississippi, 1994), and Joe R. Feagin and Melvin P. Sikes, Living with Racism: The Black Middle Class Experience (Boston, MA: Beacon Press, 1994).

${ }^{2}$ Marvin McMickle, Preaching to the Black Middle Class: Words of Challenge, Words of Hope (Valley Forge, PA: Judson Press, 2000), 14.
} 
class, the class tensions that arise in multi-classed congregations and the responsibility of the middle class to the less fortunate.

While the work is groundbreaking, the first of its kind, it is also incomplete. The author does not attempt to define constructs or to generate theory. Rather his is a solution-oriented approach that seeks to address some of the challenges faced by the Black middle class through intervention of the Black middle class church. The author relies primarily on personal experience and personal observation with the implied assumption that he indeed knows what this class wants and needs. While conceding that McMickle's experience, as a participant observer, has given him valuable insight into the Black middle class people, he chooses to speak for them, rather than allowing them to speak for themselves. Thus while the observations of McMickle are insightful, they are unproven.

Additionally, McMickle's work only examines the role of the middle class in the urban church. He does not address the phenomenon of the out-migration of the middle class into suburbia. Nor does McMickle offer strategies for pastors and churches seeking to retain their dwindling middle class congregants.

There have also been works written to address Black church growth and church planting. Stewart aptly identifies twelve principles for ministry that facilitate church growth in the African American context. 'The principles that he describes were born of participant observation. They indeed constitute a meaningful step to coding Black church growth behavior and patterns. And, while these "principles" are certainly informative, one does not know if they are normative. That is to say it is nearly impossible to describe

\footnotetext{
' Carlyle Fielding Stewart, African American Church Growth: 12 Principles for Prophetic Ministry (Nashville, TN: Abingdon Press, 1994).
} 
a phenomenon as principle that holds true for all time and has universal application. So while I am indebted to Stewart for many keen insights, they must be categorized as descriptive/informative rather than descriptive/normative. Stewart makes no delineation of socio-economic class in his work. Thus he makes the mistake of assuming that all Black worshipers share a common culture and that class differences are subordinate to the culture and therefore have little or no significance.

In a recent work, Barna and Jackson explore leadership concepts in rapidly growing African-American churches.' Based upon statistical research and qualitative observation, the authors examine several factors that contribute to church growth, including style of worship, philosophy of stewardship, and methods of evangelism. However much of the data presented do not take class or socio-economic status into consideration, and thus may not be generalizable to the African-American middle class.

The most extensive study ever conducted on the African-American church was The Black Church in the African American Experience by C. Eric Lincoln and Lawrence H. Mamiya ${ }^{2}$ One of the stated purposes of this work is to move toward the development of a sociology of Black churches. But by Black churches, the authors refer only to the seven major historic Black denominations: the African Methodist Episcopal Church, the African Methodist Episcopal Zion Church, the Christian Methodist Episcopal Church, the National Baptist Convention, USA; the National Baptist Convention of America, the Progressive National Baptist Convention, and the Church of God in Christ. These

' George Barna and Harry R. Jackson Jr., High Impact African-American Churches: Leadership Concepts from Some of Today's Most Effective Churches (Ventura, CA: Regal Books, 2004).

${ }^{2}$ C. Eric Lincoln and Lawrence H. Mamiya, The Black Church in the African American Experience (Durham, NC: Duke University Press, 1990). 
denominations comprise approximately 80 percent of all Black church members and represent a vast pool for research. The authors report that the majority of the members in the Methodist denominations are middle class. ${ }^{1}$ Yet the authors do not operationally define middle class or spend much time on examining the Black middle class as a cohort. In a chapter entitled, "The American Dream and the American Dilemma: The Black Church and Economics," the authors mention the Black middle class only briefly, and diagnose the Black middle class dilemma in a cursory manner: "The major challenge facing a predominantly middle and working class Black Church is whether it can effectively reach out to the extremely deprived members of the truly disadvantaged." It is possible that middle class Blacks might not perceive this as the major challenge facing the Black middle class church. Lincoln and Mamiya did not ask the Black middle class what they consider to be "the major challenge" facing the Black middle class church. The researcher without data to support their assertion, decided for the Black middle class.

Superlatives, such as "the greatest," must be quantified in order to be justified. Upon what basis is the assertion made? For instance, McMickle believes one of the greatest challenges is a spiritual challenge: choosing between the good life that "America offers at a price" and the abundant life that "Jesus Christ offers as a gift." While this may be true, it is not proven to be true. And so, Lincoln and Mamiya make the same methodological flaw as McMickle, the failure to distinguish between inference and fact. Thus, even the most extensive study on the Black church does not fully explore

\footnotetext{
${ }^{1}$ Ibid., 268.

${ }^{2}$ Ibid., 269.

${ }^{3}$ McMickle, 88.
} 
or adequately explain the phenomena of the Black middle class persons in relationship to the church.

Adventist researcher Monte Sahlin examined certain demographic data on the Seventh-day Adventist Church in Adventist Congregations Today: New Evidence for Equipping Healthy Churches. Sahlin reported that one third of all Adventist households are "lower middle income households with annual incomes of $\$ 25,000$ to $\$ 49,999$ and two-fifths are in more affluent households with annual incomes of $\$ 50,000$ or more." $\mathrm{He}$ concludes, "The Adventist Church in North America is largely middle class." " He also reported that 10 percent of the congregations of the SDA Church in America are Black. ${ }^{2}$ Yet he does not report income or class status by race or ethnicity. One is left to wonder whether or not the responses by the White middle class cohort are similar to or different from that of the Black middle class cohort, and how those similarities or differences may affect responses to his survey.

Hozell C. Francis explored church planting in the Africa-American context. His work applied the principles of missiology and sociology to the church planting endeavor. ${ }^{3}$ His work is insightful because it seeks to take an interdisciplinary approach at uncovering cultural factors in the African-American community that facilitate church growth. The churches to which he makes reference in his work are often older, established churches, or newly formed mega-churches. Unfortunately, Francis does not account for class differences. In fairness to the author, it is not his stated purpose to address class

\footnotetext{
${ }^{1}$ Monte Sahlin, Adventist Congregations Today: New Evidence for Equipping Healthy Churches (Lincoln, NE: Center for Creative Ministry), 42.

2 Ibid., 36.

${ }^{3}$ Hozell C. Francis, Church Planting in the African American Context (Grand Rapids, MI: Zondervan Publishing House, 1999).
} 
differences in church planting. However, because he does not address the issue of class in the African-American church planting process, one cannot apply his assertions as principles.

Mission strategists have recognized the important trend of urbanization. ${ }^{1}$ Never before has there been such a massive movement of people involving so drastic change in their lifestyle. ${ }^{2}$ But while urbanization is a growing trend in the world, suburbanization is a growing trend among the Black middle class. Yet, the researchers have yet to seriously look at this phenomenon.

\section{Diversity and Racial Reconciliation}

There is a growing body of literature on diversity in the church. Some deal with describing the various ethnicities found in the North American church. Pollard painstakingly describes some general cultural characteristics of Anglos, AfricanAmericans, Asians, and Hispanics. ${ }^{3}$ But it must be noted that these are in fact very broad generalizations that do not take into consideration the complexity of cultural, ethnic, and socio-economic diversity within the general categories, and the work certainly does not account for the factor of class. Others deal with cultural diversity in worship. Pedrito U. Maynard-Reid examines historical roots giving rise to the cultural particularities in

' Harvie M. Conn, Planting and Growing Churches: From Dream to Reality, ed. Harvie M. Conn (Grand Rapids, MI: Baker Books, 1997).

${ }^{2}$ Paul G. Hiebert, Anthropological Insights for Missionaries (Grand Rapids, MI: Baker Book House, 1985), 288-289, and Roy Branson, "Adventism's Rainbow Coalition," in Make Us One:

Celebrating Spiritual Unity in the Midst of Cultural Diversity, Removing Barriers, Building Bridges, ed. Delbert W. Baker (Boise, ID: Pacific Press Publishing Association, 1995), 60-28.

${ }^{3}$ Pollard, 33-93. 
African-American, Caribbean, and Hispanic worship, but does not look at class within each of these sub-cultures.

There is an ever-increasing body of literature on racial reconciliation. The work produced by Dennis L. Okhlm is theological. ${ }^{2}$ Okholm assembled a number of theologians to write about the meaning of theological discourse in racial reconciliation, theological method, the role of Scriptures, and the responsibility of the church. ${ }^{3}$ The vast majority of works however are prescriptive, recommending strategies for racial reconciliation. ${ }^{4}$ Yet, none of these works addresses the issue related to class and ethnicity. The apparent assumption in the literature is that consideration of class is not as important as ethnic culture in racial reconciliation.

Most of the literature, with the notable exceptions of Tatum, Patillo-McCoy, and McMickle, falls into several methodological errors. Hill identifies six critical errors in the study of Black families and class. First, is the reification of class referring to the fallacy of treating conceptual abstractions as if they existed in reality. ${ }^{5}$ For example, class categories are arbitrary distinctions that vary according to the objectives of the analyst.

\footnotetext{
' Pedrito U. Maynard-Reid, Diverse Worship: African-American, Caribbean and Hispanic Perspectives (Downers Grove, IL: InterVarsity Press, 2000).

${ }^{2}$ Dennis L. Okholm, ed., The Gospel in Black and White: Theological Resources for Racial Reconciliation (Downers Grove, IL: InterVarsity Press, 1997).

${ }^{3}$ See chapters by Ronald C. Potter, Vincent Bacote, Michael Cartwright, and Eugene Rivers in The Gospel in Black and White.

${ }^{4}$ See Rodney L. Cooper, We Stand Together: Reconciling Men of Different Color (Chicago: Moody Press, 1995); Norman Anthony Peart, Separate No More: Understanding and Developing Racial Reconciliation in Your Church. (Grand Rapids, MI: Baker Books, 2000); Michael Pocock and Joseph Henriques, Cultural Change and Your Church: Helping Your Church Thrive in a Diverse Society (Grand Rapids, MI: Baker Books, 2002); Schuler, Winning the Race to Unity: Is Racial Reconciliation Really Working?; Raleigh Washington and Glenn Kehern, Breaking Down Walls: A Model for Reconciliation in an Age of Racial Strife (Chicago: Moody Press, 1993); and Randy Woodley, Living in Color: Embracing God's Passion for Diversity (Grand Rapids, MI: Chosen Books, 2001).

${ }^{5}$ Hill, 62.
} 
The second error is the shifting of class criteria. A researcher should not apply the definition of middle class as simply white-collar professional and at other times use location or education as the criteria. The third error is static analyses or the failure of the analyst to account for the fragility of class in the Black community and to account for the fluidity of upward and downward vertical mobility. Error four is the equating of class with culture, or the failure to distinguish between situational adaptations that are reactions to current circumstances and historical adaptations that are cultural patterns transmitted intergenerationally. The fifth error is the confusion of class and race. Racial comparisons are made without any controls for socio-economic status. The sixth error is the confusing of attributes with correlates. Attributes are constants, referring to intrinsic traits of class or cultural lifestyles, while correlates are variables, extrinsic characteristics arising out of adaptation.

\section{Summary}

The review of the literature demonstrates a need for further research. Most of the historical/sociological studies do not extensively explore the role of the church in the lives of the Black middle class. The ethnographic studies describe the relationship of the Black middle class within specific communities, but because their findings are contradictory, they are not generalizable. Additionally, the ethnographs do not attempt to quantify observations so that they can be formulated into constructs. With the exception of McMickle, the studies dealing specifically with Blacks in the church do not account for class differences and tend to view the Black community as a monolith. The demographic study of Adventists by Sahlin does not factor class differences among Blacks. It is difficult to compare the data of the various studies because of the 
methodological errors of shifting class criteria, the confusion of race with class and culture. Finally, no work asked the Black middle class directly or specifically what factors influence their decision to attend or affiliate with a congregation.

Several unanswered questions arise as a result of the review of the literature. First, what sociological factors impact and influence the Black middle class to affiliate with a congregation? How does the sociology of the Black middle class give birth to the felt needs that they desire the church to meet? Second, how should theory inform methodology? Are there theories that are context appropriate? Third, how should theology inform the methodology? 


\section{CHAPTER III}

\section{METHODOLOGY}

This study shall seek to uncover three important facets of the research question. First, what are the sociological factors that impact and influence ministry to the Black middle class? Second, what theoretical frameworks inform ministry approaches to the Black middle class? Third, what are the theological implications of class and ethnicity upon ministry to the Black middle class? The methodology used is informed by the research question and the tools that are required to arrive at an answer. This section shall explain the overall methodological approach to this study and the specific methodologies applied to each aspect of the research question.

\section{Research Methodology}

The overarching methodological approach is qualitative. Qualitative research is multi-method in focus, involving an interpretive, naturalistic approach to the subject matter. This means that qualitative researchers study things in their natural settings attempting to make sense of, or interpret phenomena in terms of the meanings people bring to them. Qualitative research involves the studied use of and collection of a variety of empirical materials - observational, historical, interpretations and visual texts - the described routine and problematic moments and meanings in individuals' lives. ${ }^{1}$

\footnotetext{
${ }^{1}$ N. K. Denzin and Y. S. Lincoln, Handbook of Qualitative Research (Thousand Oaks, CA: Sage, 19.84); 2 .
} 
A qualitative approach was preferred over a quantitative approach for this study. Quantitative research begins with theory. From theory, prior research is reviewed; and from theoretical frameworks, hypotheses are generated. These hypotheses lead to data collection and the strategy needed to test them. The data are analyzed according to the hypotheses and conclusions are drawn. The conclusions confirm or conflict with the theory. ${ }^{1}$ In classical theory building, one first establishes a concept or proposition; next develops hypotheses; and lastly conducts measurements and analyses to verify the hypotheses.

Qualitative research inverts the paradigm. Data are collected and interpreted. From the analysis of the data conclusions are drawn and hypotheses generated that can be used to develop theory. The cardinal principle of qualitative analysis is that causal relationships and theoretical statements be clearly emergent from and grounded in the phenomena studied. ${ }^{2}$

This study utilizes a descriptive qualitative methodology. The sociological portion of the study is descriptive research. It seeks to collect detailed factual information that describes an existing phenomenon. In this case, the study seeks to describe the attitudes, beliefs and values of the Black middle class individual in regard to church attendance and affiliation. The purpose is to measure one or more variables that can be use to describe the group of interest. Descriptive research does not provide the researcher with

\footnotetext{
${ }^{1}$ Carolyn R. Benz and Isadore Newman, The Qualitative-Quantitative Research Methodology: Exploring the Interactive Continuum (Carbondale, IL: Southern Illinois University Press, 1998), 21-22.

${ }^{2}$ D. C. Patton, Qualitative Evaluation and Research Methods (Newbury Park, CA: Sage Publications, 1990), 278.
} 
opportunity to control or manipulate the independent variables, rather simply to note them.

Because there is not an extensive body of literature on the subject of the Black middle class church attendee, an initial study is necessary to describe the phenomena of the Black middle class church attendee. This study uses a survey to initially code the attitudes and beliefs of the Black middle class toward church attendance. To my knowledge, no other researcher has specifically asked the Black middle class what factors influence their decision in church attendance. Thus this study rather than starting with a hypothesis seeks to gather enough initial data from which a hypothesis may eventually emerge. Qualitative research is inductive rather than deductive. The survey used in this study treats the participants as a primary source from which processual analysis occurs. ${ }^{1}$

Grounded theory refers to a research process stressing discovery and theory building through methods of initial and focused coding and memo writing. In grounded theory building, one (1) collects and analyzes data; (2) considers only those variables and hypotheses that emerge form the data; and (3) formulates a concept or a proposition from the emergent relationships. ${ }^{2}$

Now that the overarching methodology is clarified, the methods used to approach each of the three aspects of the research question will be briefly discussed.

The sociological section uncovers the attitudes and beliefs of the Black middle class regarding church attendance and affiliation. Two techniques were employed in

\footnotetext{
${ }^{1}$ Benz and Newman, 193.

${ }^{2}$ Ibid., 195; and Patton, 1.
} 
exploring the sociological factors, demographics and surveys. First, demographic data was gathered from current literature, including books, articles and other medium on the "Black middle class," were reviewed. An examination of the sociological and historical factors giving rise to the "Black middle class" was conducted to provide a context through which to interpret the demographic data. Social descriptors such as income, income disparity, level of education, and gender disparity were derived from various demographic sources to compile an ethnographic profile of the Black middle class. The ethnograghic profile delineates constructs and characteristics of the group.

Second, I employed a survey to measure and code responses of the Black middle class. Analyses of the possible relationships between the demographic data, the felt needs, and the attitudes of the Black middle class toward church affiliation were undertaken. The survey uncovered measurable variables (i.e., factors that influence church attendance and affiliation).

Third, the understandings derived from the ethnograph and the survey were used to inform ministry approaches to the Black middle class.

The theoretical frameworks section evaluates various theoretical approaches to reaching Black middle class persons. Literature on social theory, congregational growth and dynamics were reviewed and principles extrapolated that are appropriate to this study.

The method used to derive the theological implications for ministry is a social description approach. Biblical literature is reviewed through a socio-historical perspective to provide theological insights on race and class in the early Christian community. The Book of Luke/Acts is explored to discover how the early church dealt 
with conflict over ethnicity and class. The subject of class and classism is discussed through the lens of the Epistle of James. The words of Christ recorded in the Epistle of John are discussed to extrapolate principles given to the early church that are still applicable today. The views of Ellen G. White on the subject of race and class are briefly discussed because they are considered to authoritative in SDA Church. The theological implications derived from this section are used to inform the ministry approaches to the Black middle class.

\section{Setting}

A survey was conducted to ascertain the attitudes, beliefs, values and preferences of Black middle class persons in regard to church attendance and affiliation. The study was conducted between November 2004 and January 2005 in two small urban cities in the Southeast United States, Huntsville, Alabama (population: 362,000), and Albany, Georgia (population: 175,000$)$. One hundred and seventy-seven $(n=177)$ Black middle class persons participated in this study.

The study was conducted in both public and private settings. I approached individuals in public locations (shopping centers, churches) and in private homes to ask if they would be willing to participate in the proposed study. In order to avoid interviewer influence or bias, I avoided interviewing friends, acquaintances, and his own students. ${ }^{1}$

In interview studies, it is impossible to employ random sampling or even a stratified random-sampling approach. ${ }^{2}$ Instead, the process of purposeful sampling was

${ }^{1}$ I.E. Seidman, Interviewing as Qualitative Research: A Guide for Researchers in Education and the Social Science (New York: Teachers College Press, 1991), 32-33.

${ }^{2}$ Ibid., 42. 
used. ${ }^{1}$ Purposeful samples include typical case, extreme or deviant case, critical case, sensitive case, convenience sampling and maximum variation sampling. ${ }^{2}$ This study used a sampling of convenience: those individuals who were available and who fit the criteria. The pool of participants was made by (1) direct and personal contact of the researcher; (2) an assessment of the appropriateness of the participant for the study was conducted based upon the prescribed ethnicity, income and class criteria. ${ }^{3}$ Individuals not meeting the criteria for the study were excluded from the pool.

\section{Procedures}

\section{Participant Criteria}

Participants had to fit the following criteria: (1) be at least eighteen years old, (2) be a self-described Black person (a person of African descent), (3) meet the income criteria of between $\$ 19,400$ and $\$ 100,000$ for a single person, or between $\$ 25,000$ and $\$ 100,000$ for a family of four, and (4) be a current resident of the United States.

\section{Ethical Consideration of Human Subjects}

The interviews were conducted under strict ethical standards. The following guidelines were used:

1. The identity of the researcher and his affiliations were made known to the participants, and contact information was given.

\footnotetext{
${ }^{1}$ M.Q. Patton, Qualitative Evaluation Methods (Beverly Hills, CA: Sage Publications, 1989), 102.

${ }^{2}$ Ibid., 100-107.

${ }^{3}$ Seidman, 42 .
} 
2. Participants were informed of the purpose of the study, and what they were being asked to do.

3. All information gathered from the subjects is confidential. Surveys are catalogued by number and the names of subjects are not used.

4. Data collected were for the purpose of research and were used only for the stated purpose of the study conducted.

5. Subjects were informed of any features of the study that might influence them in deciding whether or not to participate. Each subject gave informed consent before participating in the study.

6. Subjects were free to stop participating at any point during the research without penalty.

7. There was no compensation offered or proffered for participation in this study.

8. Study participants were not subjected to any mental or physical discomfort. If discomfort was possible during the study, informed consent would be the governing rule.

9. Subjects were debriefed and were given a complete explanation of the purpose of the study, and the procedures that were used in the study.

\section{Data Collection}

For this study the survey method was used to collect data. This method was selected because it is descriptive. First, it provides direct information about the values, attitudes and priorities of the Black middle class person concerning church attendance. Second, the data provide information about other sociological or psychological 
variables. ${ }^{1}$ Third, collected can be coded by response. Fourth, coded responses assist in the development of constructs. Thus, the survey method was selected because it is deemed the most appropriate means describing the reality of the Black middle class persons.

African-Americans are reluctant to participate in survey research for fear of exploitation. ${ }^{2}$ Therefore an interview survey approach was taken. Once informed consent was granted, I distributed the questionnaire to the participant. I provided explanation of the questions and definition of the terms. When a participant, for any reason, could not or chose not to read the instrument, I read the survey to them and recorded their responses. In such instances, verbal verification of the response was sought.

The surveys were screened and those not meeting the research criteria were eliminated. Each survey was assigned an index reference number. The responses to each survey were coded according to the survey question and tallied in Microsoft Excel. The data were transferred to SPSS for frequency and cross tabulations. Correlations were conducted but are not reported in this study.

\section{Survey Construction}

The demographic questions with the wording and choices are exactly as they are asked in the Gallup surveys. The questionnaires have been designed for telephone, personal interview and self-administration of adults over the age of eighteen. They have

\footnotetext{
${ }^{1}$ Richard C. Sprinthall, Gregory T Schmutte, and Lee Sirois, Understanding Educational Research (Englewood Cliffs, NJ: Prentice Hall, 1990), 93.

${ }^{2}$ Margaret L. Anderson, "Studying Across Difference: Race, Class, and Gender in Qualitative Research," in Race and Ethnicity in Research Method, ed. John H. Stanfield II and Rutledge M. Dennis (Newbury Park, CA: Sage Publications, 1993), 41.
} 
been field tested for validity by the Gallup organization. Permission is granted by the Gallup organization to either photocopy pages, reproduce the printed surveys used in this study or to download the PDF files of the surveys at www.grouppublishing.com/gallup/surveys. ${ }^{1}$

The descriptive survey responses for this study were modeled after the Gallop "Sample Survey 8." "Survey 8 "is a self-administered questionnaire designed for new members at a local congregation, and it queries respondents on the importance and effectiveness of various church programs." 2 This sample survey was chosen for this study because the questions are also appropriate to those contemplating joining a church. For example, question 1 which asks, "Which of the following were factors in your decision to join this church?" was transposed in this study to read, "Which of the following are or would be important factors in your decision to join a church?" 3 "Survey 8 ' also gave the respondents opportunity to rate the importance of an answer. This was also useful in this study because it affords the opportunity to distinguish between factors that the respondents consider important versus those considered essential. Question 7 on "Survey 8" asks the respondent to rate emphasis given to particular mission/outreach/lifestyle ministries. ${ }^{4}$ The format and intent of Gallup's mission/outreach/lifestyle ministries questions were modified to reflect some of the major

\footnotetext{
${ }^{1}$ George Gallop and D. Michael Lindsay, The Gallop Guide: Reality Check for $21^{\text {st }}$ Century Churches (Loveland, CO: Group, 2002), 74.

${ }^{2}$ Ibid., 76.

3. Ibid., 113.

${ }^{4}$ Ibid., 115.
} 
issues facing the Black community: AIDS, criminal justice, career development, support for children of the incarcerated, and teen pregnancy.

In addition, the work Barna and Jackson was instrumental in determining what factors needed to be explored in the survey.' Barna and Jackson studied several AfricanAmerican churches affiliated with the ten major Black denominations and identified eight characteristics of what they call "high impact African American churches:"

(1) Leadership, (2) Discipleship, (3) Worship, (4) Evangelism, (5) Family, (6) Stewardship, (7) Community, (8) Relationships.

These eight characteristics identified by Barna and Jackson have some overlap with those identified by Christian Schwartz in his work Natural Church Development. ${ }^{2}$ Christian Schwarz has conducted the most extensive study ever on the growth characteristics of churches. Over 10,000 churches in across many cultures and nations are included in his database. His characteristics include: (1) Empowering Leadership, (2) Gift-Oriented Ministry, (3) Passionate Spirituality, (4) Functional Structures, (5) Inspiring Worship Service, (6) Holistic Small Groups, (7) Need-oriented Evangelism, (8) Loving Relationships.

How do these characteristics coincide with those listed by Barna and Jackson? Are there any similarities or overlap? Since Barna and Jackson specifically survey African-American churches? Is their investigation more reliable? Or, because Schwartz's research was so global and claims to have identified universal principles is it more reliable and valid? A comparison of the two sets of characteristics for church

\footnotetext{
${ }^{1}$ Barna and Jackson, 46-91.

${ }^{2}$ Christian A. Schwarz, Natural Church Development: A Guide to Eight Essential Qualities of Healthy Churches (Carol Stream, IL: ChurchSmart Resources, 1998).
} 
growth demonstrates possible agreement or overlap. Terminology may be different, but readings of the authors' intent show congruence. A comparison of terms and concepts used by Barna and Jackson and those used by Schwarz is presented in table 1 .

\section{TABLE 1}

\section{TERMINOLOGY COMPARISON: BARNA/JACKSON AND SCHWARZ}

\begin{tabular}{|c|c|}
\hline Barna and Jackson Term or Concept & Schwarz Term or Concept \\
\hline $\begin{array}{l}\text { Leadership ( successful leadership in } \\
\text { the Black Church) } \\
\text { - pastor as change agent } \\
\text { - communication that inspires } \\
\text { - leadership in the team context } \\
\text { - refusal to micromanage } \\
\text { - investment in developing } \\
\text { - impact through collaboration } \\
\text { - impact }\end{array}$ & $\begin{array}{l}\text { Empowering leadership. } \\
\text { Functional Structures. }\end{array}$ \\
\hline Discipleship & Holistic small groups \\
\hline Worship & $\begin{array}{l}\text { Inspiring worship. } \\
\text { Passionate spirituality }\end{array}$ \\
\hline Evangelism & Need-oriented evangelism. \\
\hline Family & Holisitic small groups. \\
\hline \multicolumn{2}{|l|}{ Stewardship } \\
\hline \multicolumn{2}{|l|}{ Community } \\
\hline Relationships and family & Loving relationships. \\
\hline
\end{tabular}

In the construction of this survey, each of the questions was designed to assess the responses to one or more of the key areas identified by Barna and Jackson and/or Schwarz. For example, because Barna and Jackson identify the role of the pastor in church as vital to church growth in the African-American church, a question was 
included to assess the role of and the importance of the pastor in church growth. Because inspiring worship service is identified by both Barna and Jackson, and Schwarz as critical growth characteristics, I included two questions on worship, one to identify elements considered important in worship and another to identify preference for worship.

\section{Survey Demographics}

Demographic variables are presented to provide insight into the make-up of the respondents to the survey. Data presented include age, gender, education, and income. Other variables addressed include household size, employment status, type of employment, location of residence, and church affiliation. Demographic data on these variables appear in table 2.

Age

The age of respondents ranged from 18 to 65 (table 2). No person under the age of 18 was included in this study. Persons over the age of 60 gave their exact ages. More than 50 percent are 36 years old or older.

\section{Education}

More than 22 percent of respondents attended or graduated high school and/or attended trade or technical school (table 2). Seventy-seven percent attended college or graduate/professional school.

\section{Income}

Income data are reported in ranges (table 2). Income distribution ranged from $\$ 19,400.00$ to over $\$ 90,000.00$. The median income range is $\$ 40,000-\$ 50,000$. Forty 
percent of respondents earn an income that exceeds $\$ 50,000$. Eleven percent of respondents earn income that exceeds $\$ 90,000$.

TABLE 2

DEMOGRAPHICS: GENDER, AGE, EDUCATION AND INCOME

\begin{tabular}{lcc}
\hline Demographic & $N$ & Percentage \\
\hline \hline Gender & 66 & \\
Male & 111 & 37.3 \\
Female & 5 & 62.7 \\
Age & 82 & 2.8 \\
$<21$ & 49 & 46.3 \\
$21-35$ & 27 & 27.7 \\
$36-45$ & 13 & 15.3 \\
$46-60$ & & 7.3 \\
$60+$ & 7 & 4.0 \\
Education & 23 & 13.0 \\
Some high school & 10 & 5.6 \\
High School Graduate & 61 & 34.5 \\
Trade/technical school & 76 & 42.9 \\
Attended college & & \\
Graduate/professional & & 15.8 \\
& 28 & 15.3 \\
Income & 27 & 12.4 \\
$<\$ 20 K$ & 22 & 16.4 \\
\$20-\$30K & 29 & 8.5 \\
\$30-\$4OK & 36 & 11.3 \\
\$40-\$5OK & 15 & \\
\$50-\$7OK & 20 & \\
\$70-\$9OK & & \\
\$90K & & \\
\hline \hline
\end{tabular}

A look at income by gender indicates relative parity of income distribution by gender with some notable exceptions. Although females constitute 63 percent of the population surveyed, they represent 75 percent of those reporting less than $\$ 20,000$ in family income. Males, more than females, earn an income between the $\$ 30,000$ to $\$ 40,000$ range. Of males, who make up 37.3 percent of respondents, 50 percent of those reporting family income between $\$ 70,000$ and $\$ 90,000$. Of females, who make up 63 percent of respondents, 67 percent of those reporting family income between $\$ 50,000$ and 
$\$ 70,000$. Even though females outnumber males in this study, there is representation across gender in income ranges.

\section{Marital Status}

More than half of the respondent population is married or has been married (table 3). Forty percent have never been married. These data do not reveal what percentage of the population was previously divorced or widowed and who are presently married.

\section{TABLE 3}

DEMOGRAPHIC: MARITAL STATUS

\begin{tabular}{lcc}
\hline Demographic & $N$ & Percentage \\
\hline \hline Marital Status & & \\
Married & 86 & 48.50 \\
Widowed & 3 & 1.69 \\
Divorced & 20 & 11.30 \\
Never Married & 69 & 38.90 \\
Sharing with Partner & 1 & 0.05 \\
& 1 & 0.05 \\
\hline
\end{tabular}

Cross-tabulation of marriage status by income reveals that marriage increases family income. Thirty-two percent of those earning under $\$ 20,000$ and 20 percent of those earning between $\$ 20,000$ and $\$ 30,000$ were married. Sixty-five percent of those earning between $\$ 40,000$ - $\$ 50,000$ were married. The highest correlation of marriage to income was seen in those earning in excess of $\$ 90,000 ; 75$ percent were married.

\section{Home Ownership and Location}

More than half of respondents are homeowners. Almost 48 percent do not (see table 4). Results indicate that respondents dwell in a variety of locales. A little over 
half live in what they describe as urban areas, with 37 percent living in the suburbs and 10 percent live in rural areas.

\section{TABLE 4}

DEMOGRAPHICS: HOUSEHOLD, HOME OWNERSHIP, HOME LOCATION

\begin{tabular}{lcc}
\hline \hline Demographic & $N$ & Percentage \\
\hline \hline Size of Household & 36 & \\
1 person & 43 & 20.3 \\
2 persons & 26 & 24.3 \\
3 persons & 43 & 14.7 \\
4 persons & 20 & 24.3 \\
5 persons & 6 & 11.3 \\
6 persons & 1 & 3.4 \\
7 persons & & .6 \\
Home Ownership & 92 & \\
Yes & 84 & 52.0 \\
No & & 47.5 \\
Home Location & & \\
City & 92 & 52.0 \\
Suburb & 65 & 36.7 \\
Rural & 18 & 10.2 \\
\hline
\end{tabular}

\section{Employment Status and Type}

Almost 60 percent of survey participants are full-time employees (table 5). Other respondents work part-time or do not work at all (14 percent). Less than 42 percent of respondents are professionally employed. Forty-five percent report that their work is trade-related or technical/administrative support-related. About 16 percent are business owners.

\section{Church Membership and Attendance}

Ninety-two percent of respondents identified themselves as a church member (table 6). Less than 10 percent are not church members. Most of those who responded 
"no" to church membership were able to identify a church or denominational preference.

Sixty-four percent of respondents report that they attend church on a weekly basis.

Thirteen percent attend only on special occasions, once a month, or annually.

TABLE 5

DEMOGRAPHICS: EMPLOYMENT STATUS AND TYPE

\begin{tabular}{lcc}
\hline Demographic & $N$ & Percentage \\
\hline Employment Status & 106 & 59.9 \\
Full-time & 45 & 25.4 \\
Part-time & 19 & 10.7 \\
Not employed & 6 & 3.4 \\
Retired/disabled & & \\
Profess. Employment & 74 & 41.8 \\
Yes & 100 & 56.5 \\
No & & \\
Trade/Tech/Ad. Support & 80 & 45.2 \\
Yes & 96 & 54.2 \\
No & & \\
Business Ownership & & 15.8 \\
Yes & 28 & 81.9 \\
No & 145 & \\
\hline \hline
\end{tabular}

TABLE 6

DEMOGRAPHICS: CHURCH MEMBERSHIP AND ATTENDANCE

\begin{tabular}{|lcc|}
\hline Demographic & $N$ & Percentage \\
\hline \hline Church Membership & 163 & \\
Yes & 14 & 92.1 \\
No & & 7.9 \\
& 11 & \\
Attendance Frequency & 7 & 6.2 \\
Once or twice/year & 40 & 4.0 \\
Once/month & 114 & 22.6 \\
At least twice/month & 5 & 64.4 \\
Once/week & 2.8 \\
Special occasions & \\
\hline
\end{tabular}


Denominational Affiliation/Preference

Respondents are affiliated with a variety of church denominations. Just under 50 percent (48.6 percent) are affiliated with the Baptist church. See table 7.

TABLE 7

DENOMINATIONAL AFFILIATION/PREFERENCE

\begin{tabular}{lcc}
\hline Denominational & $N$ & Percentage \\
Affiliation & 86 & 48.6 \\
\hline \hline Baptist & 53 & 29.9 \\
Seventh-day Adventist & 4 & 2.3 \\
Methodist & 1 & .6 \\
Non-Denominational & 8 & 4.5 \\
Presbyterian & 1 & .6 \\
Pentecostal & 8 & 4.5 \\
Church of God in Christ & 2 & 1.1 \\
Apostolic & 1 & .6 \\
Catholic & 3 & 1.7 \\
Church of God & 1 & .6 \\
Rastafarian & 1 & .6 \\
Christian & 1 & .6 \\
United Church of Christ & & \\
\hline
\end{tabular}

\section{Summary}

The data indicate that the Black middle class persons surveyed are educated, employed and earning solid incomes. Over 40 percent are professionals and 15 percent are business owners. Most households are small and do not have more than four persons in the family. They are predominantly church attendees, with the majority attending over twice per month. About one half is home owners and over one third report that they live in the suburbs. 


\section{CHAPTER IV}

\section{THE RISE OF THE BLACK MIDDLE CLASS: DEMOGRAPHIC TRENDS AND ETHNOGRAPHIC PROFILE}

In 1957, racial segregation still plagued much of the country. Discrimination in housing and employment were still largely practiced and legally sanctioned. Thus, while the Black middle class existed, it more closely represented the "talented tenth" referred to by Dubois.' Black professionals made up this group, including doctors, lawyers, teachers, ministers, and small business owners. But by the 1970 s the middle class had expanded to include new professionals such as career police officers, highly skilled factory workers, engineers, and accountants. ${ }^{2}$ Gates reports that in 1950 only 5 percent of the Black workers held managerial or professional jobs: in 1998 the number was over 20 percent. The number of Black families earning more than $\$ 50,000$ has quadrupled since 1967 and doubled in the 1980 s alone. $^{3}$

Several factors precipitated this increase in the Black middle class. First and foremost was the legal end of discrimination and the opportunities that it created for Blacks. In 1957, the Congress of the United States passed the first civil rights act since

\footnotetext{
${ }^{1}$ DuBois took the position that 10 percent of the Black community possessed the intellectual capacity and therefore had a responsibility to lead the other 90 percent of the race into political and economic enfranchisement. These gifted and privileged leaders he called the "talented tenth." See W.E.B. DuBois, The Souls of Black Folk. (New York: Penguin Books, 1989).

${ }^{2}$ Bart Landry, The New Black Middle Class (Berkeley, CA: University of California Press, 1987).

${ }^{3}$ Henry Louis Gates, Jr, "Frontline: The Two Nations of Black America," http://www.pbs.org/wgbh ( acessed 18 Novenber 2004).
} 
1875. The law created a United States Commission on Civil Rights to investigate allegations of denial of voting privilege and to appraise the Federal Government on laws and policies with respect to equal protection. ${ }^{1}$ But the most far-reaching legislation was the Civil Rights Act of 1964. Says Franklin:

It gave the attorney general additional power to protect citizens against discrimination and segregation in voting, education, and the use of public facilities. It forbade discrimination in most places of public accommodation and established a federal Community Relations Service to help individuals and communities solve civil rights problems. ${ }^{2}$

These laws and other federal mandates brought the legal end of discrimination in education, housing, employment, and politics. With protected access to educational opportunities, more Blacks began to seek higher education. Colleges and universities in order to maintain federal funding, began to not only open their doors to Blacks, but also to actively recruit them. The end of housing discrimination opened the suburbs and other communities to Black professionals. Loraine Hansbury captures this era of neighborhood desegregation in her work, $A$ Raisin in the Sun, in which a Black family is able to move into a previously excluded neighborhood when they receive an insurance settlement. ${ }^{3}$ The end of discrimination in employment and the awarding of government contracts allowed newly educated Blacks access to highly paid professional positions while those with lesser education were able to move into trades and trade unions. Having received the right to vote, Blacks began to exercise their franchise.

But, the rise of the Black middle class is not just the by-product of the removal of legal sanctions. That would suggest that the Black middle class was simply the passive

\footnotetext{
1 John Hope Franklin, From Slavery to Freedom (New York: McGraw Hill, 1994), 475.

${ }^{2}$ Ibid. 487.

${ }^{3}$ Loraine Hansbury, A Raisin in the Sun (New York: Signet Books, 1958).
} 
receiver of opportunities created for them. The Black middle class did not simply receive opportunities, they helped to create them. It was the advocacy of the Black middle class through organizations such as the National Association for the Advancement of Colored People (NAACP) that forced the government to revise federal laws. It was the Black middle class that supported historically Black colleges and universities as a means of self-improvement and empowerment. ${ }^{1}$ And when the legal barriers to access were eradicated, the Black middle class was the first to enter corporate America, hostile neighborhoods, and unwelcoming schools. Thus the factors giving rise to the Black middle class were the removal of legal barriers, the challenge to the system of racial segregation by the advocacy of a coalition between the Black middle class and other concerned citizens and personal resistance to the system by Blacks everywhere. It embodies social change and personal transformation.

\section{Demographic Trends of the Black Middle Class}

One of the tragic mistakes of researchers has been the tendency to view the Black community as monolithic. The basic assumption has been that there is only one Black community: one that is poor, urban, undereducated, unemployed or underemployed composed of by single-parent households, on welfare, and on parole or in jail. Thus, when speaking of Black people, the tendency has been to refer only to the perceived social pathology in the Black community. Hill remarks:

Another common practice is the confusion of class and race. This shortcoming occurs frequently in studies that focus on racial comparisons without any controls for socioeconomic status. Such analyses often result in generalizations about differences between Blacks and Whites that are attributed to race. Most studies, for example, that

\footnotetext{
' Juan Williams and Dwayne Ashley, I'll Find a Way or I'll Make One: A Tribute to Historically Black Colleges and Universities (New York: Amistad/Harper Collins Publishers, 2004), 144-148.
} 
compare such attributes as female headed families of out-of wedlock births among Blacks to Whites, rarely control for social class. Such comparisons are misleading because the analyses are actually comparing a mostly middle income racial group (Whites) with a mostly low-income racial group (Blacks). ${ }^{1}$

Even the term "Black community" is a misnomer, as though there is only one community that reflects a common culture, class, and ethnicity. It is certainly less common to describe all White Americans with the broad brush of the "White community." There are many Whites communities and constituencies: some are poor, some wealthy, some conservative and southern, some northern and liberal. And there is also great diversity among Black peoples in America. Lawrence Otis Graham documented the Black upper class in his 1999 book, Our Kind of People: Inside America's Black Upper Class. ${ }^{2}$ Many Americans did not know there was a Black upper class, because much of the discussion of the so-called "Black community" examined only the underclass.

There are many Black communities; some share regional identity and customs, some share political and social values, while others share general educational attainments. All Black people do not share class and culture. The Gullah of the Sea Islands off the coast of South Carolina and Georgia do not resemble in culture or class the elite Boule of Atlanta only a few hours west. ${ }^{3}$ So, one may not assume that the Black middle class is the same as the Black underclass.

\footnotetext{
' Hill, 68.

2 Lawrence Otis Graham, Our Kind Of People: Inside America's Black Upper Class (New York: Harper Collins, 1999).

${ }^{3}$ Graham describes the Boule in his book along with other upper class social organizations such as Jack and Jills, The Rainbow Yacht Club, and various fraternities and sororities.
} 
Neither does the term Black middle class necessarily indicate that their experience is the same as that of the White middle class. Racism still plays a significant role in the lives of the Black middle class. Andrew Hacker in his book, Two Nations: Black and White, Separate, Hostile and Unequal, points out the persisting inequities in society based upon ethnicity in the areas of education, employment, and income. ${ }^{1}$ The Black middle class differs from the White middle class in numerous ways. The Black middle class generally earns less. They generally are first-generation college educated, and frequently second-generation college educated. ${ }^{2}$ As shall be demonstrated, they generally have fewer assets, fixed or liquid. The Black middle class is increasingly female. And, the Black middle class treasures African-American culture. New studies show that although the Black and White middle classes may possess similar income, they may not necessarily possess the same power or prestige. "The upward strides of many African Americans into the middle class have given the illusion that race cannot be the barrier that some make it out to be. The reality, however, is that the Black and White middle classes remain separate and unequal." What follows is an examination of factors that impact the Black middle class, including economic factors, achievement gaps, and gender gaps.

\footnotetext{
'Andrew Hacker, Two Nations: Black and White, Separate, Hostile and Unequal (New York: Ballentine Books, 1992).

${ }^{2}$ Billingsly, Climbing Jacob's Ladder: The Enduring Legacy of African American Families, 279.

${ }^{3}$ Sheryl Cashin, The Failure of Integration: How Race and Class Are Undermining the American Dream (New York: Public Affairs, 2004).

${ }^{4}$ Patillo-McCoy, Black Picket Fences, 2.
} 


\section{Black Middle Class Income and}

Key Economic Factors

Some 51 percent of Black married households had incomes of $\$ 50,000$ or more in $2000 .{ }^{1}$ On the average Black suburban households had median incomes that were 44 percent higher than their peers living in the cities, and 10 percent boasted incomes of at least $\$ 100,000$. And yet, despite the growth of income among the Black middle class, income disparity still exists when compared with its Whites counterpart (see Table 8).

TABLE 8

MEDIAN INCOMES AND EARNING PERCENTAGES FOR BLACKS AND WHITES IN SELECT US CITIES

\begin{tabular}{lccc}
\hline \hline City & $\begin{array}{c}\text { Income: } \\
\text { Whites }\end{array}$ & $\begin{array}{c}\text { Income: } \\
\text { Black }\end{array}$ & $\begin{array}{c}\text { Black earnings } \\
\text { per \$1 Whites }\end{array}$ \\
\hline \hline Detroit & $\$ 29,404$ & $\$ 29,647$ & $\$ 1.01$ \\
San Jose & $\$ 72,179$ & $\$ 58,157$ & $\$ 0.81$ \\
Baltimore & $\$ 37,054$ & $\$ 26,202$ & $\$ 0.71$ \\
Columbus & $\$ 41,471$ & $\$ 29,214$ & $\$ 0.70$ \\
San Diego & $\$ 49,987$ & $\$ 34,539$ & $\$ 0.69$ \\
Phoenix & $\$ 44,345$ & $\$ 30,276$ & $\$ 0.68$ \\
New York & $\$ 46,534$ & $\$ 31,058$ & $\$ 0.67$ \\
Chicago & $\$ 46,680$ & $\$ 29,086$ & $\$ 0.62$ \\
Los Angeles & $\$ 44,841$ & $\$ 27,310$ & $\$ 0.61$ \\
\hline Source: Brad Heath. “Prosperity Can't Close Metro Area Income," The Detroit News, 10 \\
September, 2002, http://www.detnews.com/2002/census/0212/19/a01-583173.htm (accessed 18 \\
November 2004).
\end{tabular}

\footnotetext{
${ }^{1}$ Gene Koretz, "Economic Trends: Great Strides for US Blacks," Business Week, 3 September, 2001 http://www.businessweek.com/magazine/ content/01_36/c3747033.htm (accessed 13 February 2005).
} 
But the comparisons of Black and White incomes do not reveal the whole story.

There is a difference between wealth and income. Wealth is measured not by income but by net worth. The Washington Post reports:

In 1999, before the recession hit, the median Hispanic household had a net worth of $\$ 10,495$, the median Black household had $\$ 8,774$ and the median White household had $\$ 86,370$, a gain since 1996 for every group.

In 2002, White families' median net worth was up $\$ 2,281$ from 1999 and $\$ 13,169$ from 1996. Hispanic households' median net worth stood at $\$ 7,932, \$ 1,000$ more than before the boom but down from 1999. Black families had about $\$ 1,000$ less than in $1996 .{ }^{1}$

The wealth gap exists because there is also an investment gap. Given the fact that many Black middle class individuals may not have had much exposure to information about investments, they generally lag behind their White counterparts in both the amount of income invested as well as the knowledge of the types of investments. Glenn C. Loury, a Black investment broker, reports, "My conversations with Black professionals ... [reveal that] even among well-educated persons with high income, many lack knowledge or (or confidence in) today's variegated financial instruments." 2

One's credit worthiness can determine access to goods and services. Most businesses, homes, cars, and education are financed through credit. The lower the interest rate paid to a creditor, the more the consumer has for savings and investment--the road to true financial independence. However, Blacks in the United States consistently pay higher interest rates than their White counterparts. These higher interest loans ranging from 12 percent to 24.9 percent are sometimes two to three times higher than what

\footnotetext{
' Griff Witte and Nell Henderson, "Wealth Gap Widens for Black, Hispanics," The Washington Post, 18 October, 2004, A 11 http://www.washingtonpost.com/wp-dyn/articles/A40455-2004Oct17.html (accessed 13 February 2004).

${ }^{2}$ Glenn C. Loury, “Why More Blacks Don't Invest," The New York Times Sunday Magazine, 7 June, 1998 www.bu.edu/irsd/articles/whyinvest.htm (accessed 18 October, 2004).
} 
Whites pay. According to Tony Pugh, "Low income Blacks ... were 2.4 times more likely than poor Whites to get sub-prime loans. Upper income Blacks were three times more likely than Whites with equal income."1

In a study of lending patterns in New York City, United States Senator Charles Schumer discovered several disturbing trends. First, Black neighborhoods at all income levels were six times more likely than Whites neighborhoods to rely on sub-prime lenders. Second, Black middle class neighborhoods are three times more likely to rely on sub-prime lenders than comparable White neighborhoods. Third, nearly one half (46.8 percent) of mortgage and refinance loans in Black middle class neighborhoods were made by sub-prime lenders. Fourth, denial rates for mortgage and refinance loans from conventional banks among New York City Blacks with incomes greater than $\$ 59,760$ (120 percent of the area's median income) were 20 percent compared to 10.1 percent for comparable Whites. ${ }^{2}$

It is clear that capital markets and conventional banks do not view the Black middle class consumer in the same manner as his or her White counterpart. The overall effect of disparate lending patterns is the erosion of the real income of the Black middle class. $^{3}$ And because lending patterns impact the types and the amounts of mortgages for which one may qualify, Black middle class neighborhoods do not have equal access to lending as predominantly White neighborhoods. Despite similar salaries and educational

1 Tony Pugh, "Minorities likely to get worse mortgage rate," Akron Beacon Journal 2 May 2002, http://www.butera-andrews.com/legislative-updates/directory/Media/Articles/Subprime \%20News\%20Clips\%2005-02-2002.pdf (accessed 18 November 2004).

${ }^{2}$ Charles Schumer, "Capital Access: Lending Patterns in Black and White Neighborhoods Tell a Tale of Two Cities" Unpublished MS, http: schumer.senate.gov/SchumerWebsite/media/capitalaccess.pdf (accessed 18 November 2004).

${ }^{3}$ Arthur Lewin. "A Tale of Two Classes: The Black Poor and the Black Middle Class." in Black Scholar 21, no. 3 (1990-91), 7-13. 
backgrounds, the Black middle class does not enjoy the same amenities as similar White neighborhoods. A neighborhood's ethnic make-up is frequently a proxy for the things that really count: quality schools, security, appreciation of property values, and political clout. $^{1}$

The income gap may be not only because of race but also because of the newly attained status of the Black middle class. Billingsly observes:

Most middle-class Blacks are still first generation middle class. In the foreseeable future they may continue to be characterized by their precariousness, as more codependent than independent, more employees of others than owners and managers, and with relatively little accumulated wealth. Moderate and even high salaries and income will not automatically translate into wealth, which refers to the net value of assets over liabilities. $^{2}$

\section{Achievement Gap}

"Achievement gap" is a term used by educators to describe the measurable difference of test scores among various sets of students. Very often the term is used to describe the gap between students of different ethnic groups. For years, researchers have postulated that the achievement gap on standardized tests between White students and

Black students could be attributed to parents having less income and education.

But data showed that the children of middle class Black parents still scored below the children of middle class White parents. The 1994 National Assessment of Educational Progress $12^{\text {th }}$ grade reading score, for instance, showed the Black-White gap larger for Black students with a college-degreed parent, than it was for students whose parents had no high school diploma. ${ }^{3}$

${ }^{1}$ Patillo-Mcoy, Black Picket Fences, 30.

${ }^{2}$ Billingsly, Jacob's Ladder, 287.

3 Jay Mathews, "Blacks Battle the Achievement Gap: Parents Unite to Make Sure Students Aren't Shortchanged," The Washington Post, 31 December 2000, C01 http://www.washingtonpost.com/ac2/ wp-dyn/A2297-2000 (Accessed 12 December 2002). 
Seeking to find an explanation for this troubling data, some have speculated that Blacks are less intelligent than Whites. ${ }^{1}$ However, Jay Matthews comments on an alternative explanation. It states, "Our results imply that it takes at least two generations for changes in parental socioeconomic status to exert their full effect on parenting practices that affect school achievement." ${ }^{, 2}$ Matthews reports:

Comparing middle-class Black and Whites families just by income levels, for instance, might disguise the fact that the Black family, newly arrived in suburbia, may be more burdened with debt and less likely to have affluent and educated family members, such as grandparents, who influence children's academic achievement. ${ }^{3}$

Research indicates that having money, being educated, and living in the suburbs is still not enough to close the gap. Some have speculated that integration and the acceptance of White middle class values by the Black middle class have actually had a negative effect on Black achievement. ${ }^{4}$

\section{The Gender Gap}

It is without question that educational opportunities have contributed to the rise of the Black middle class. According to the US Census Bureau, in 2002, 17 percent of Blacks (ages 25 years and over) held college degrees--up from 15 percent the previous year. However, when one examines the statistics by gender, an interesting picture

\footnotetext{
${ }^{1}$ For a more thorough discussion of race and intelligence see Steven Fraser, ed., The Bell Curve Wars: Race, Intelligence, and the Future of America (New York: Basic Books, 1995). This essay anthology was written to refute Richard J. Herrnstein and Charles Murray, The Bell Curve: Intelligence, Class Structure in America (New York: Free Press, 1994), which postulates the Blacks are inherently and genetically less intelligent than Whites as proven by the bell curve on IQ test scores.

${ }^{2}$ Matthews, $\mathrm{C} 01$.

${ }^{3}$ Ibid.

${ }^{4}$ For further discussion, see Sheryl Cashin, The Failures of Integration.
} 
emerges. While 25 percent of Black males attend college, 35 percent of Black females attend college. The national ratio of Black males to females enrolled in college is 44:56. ${ }^{1}$

The gender gap in education translates into the gender gap in employment. Black women are achieving greater success in the professions than Black men. While 24 percent of Black women are in the professional-managerial class, only 17 percent of Black males are professional-managers. In 2002, Black women, who are only about 6 percent of the US population, constituted 16 percent of corporate officers in Fortune 500 companies. $^{2}$ Says Farai Chideya:

Black female college graduates earn slightly (less than one percent) more than their White counterparts. This may be because African-American women are the sole earners for their families, and thus must put an extremely high priority on advancing their careers. It may also be because many employers feel that Black women are diversity 'two-fers'--African-American and women--and thus may favor them over Black men. ${ }^{3}$

Whatever the explanation, the data indicate that Black males are lagging behind Black females in education and income. This gender gap is causing strain in Black male and female relations, a tension that can only be expected to rise if the trend continues.

Black middle class women are often feeling the strain of loneliness because of the inability to find a man of their social class. Bakari Kitwana discusses the tension:

Simply put, Black women resent (or at least feel some anxiety toward) Black men due to the failure of Black men to compete and hence bring the race on equal footing with their White counterparts. Likewise, many young Black men resent (or at least feel some anxiety toward) Black women because of the success they've enjoyed in contrast to the overwhelming failure of Black men. Although racism is publicly

1 Ellis Cose, "The Black Gender Gap," Newsweek, 3 March 2003, 46-51.

${ }^{2}$ Ibid.

${ }^{3}$ Farai Chideya, Don't Believe the Hype: Fighting Cultural Misinformation about African Americans (New York: Penguin Press, 1995), 121. 
rationalized as the cause of his state of affairs, when it comes down to what we personally want in our partners that same racism remains largely overlooked. ${ }^{1}$

"Shifting" is a term coined by Jones and Shorter-Gooden to describe the "double lives of Black women in America." It details their struggles for acceptance and equity in the workplace, their attempts to balance relationships, and "psychic energy on managing threats of racial and gender bias." Revealing their plight, the authors write:

And so they do what we call "shifting." African American women change the way they think of things or the expectations they have for themselves. Or they alter their outer appearance. They modify their speech. They shift in one direction at work each morning, then in another at home each night. They adjust the way they act in one context after another. They try to cover up their intelligence with one group of friends and do everything possible to prove it to another. They deny their sadness and loneliness. They shift inward, internalizing the searing pain of going out into the world day after day and hitting one wall after the next, solely because they are Black and female. ${ }^{2}$

Whatever may be the cause of the gender gap in the Black middle class, it is obvious that that gap has created pain in both included females and excluded males, and created a social rift between the genders. This has tremendous implications for ministry in the church.

The Rage of the Privileged Class

As a number of writers and scholars have looked at the phenomena of the Black middle class, they have begun to articulate both a widening gap between Blacks and Whites in this country and a growing discontent among the Black middle class.

Steinhorn and Diggs-Brown attempted to explode the myth of integration and its illusion

\footnotetext{
' Bakari Kitwana, The Hip Hop Generation: Young Blacks and the Crises in African American Culture (New York: Basic Civitas Books, 2002), 107.

${ }^{2}$ Charisse Jones and Kumea Shorter-Gooden, Shifting: The Double Lives of Black Women in America (New York: HarperCollins Publishers, 2003), 61.
} 
of full enfranchisement in the book, By the Color of Our Skin: The Illusion of Integration and the Reality of Race. ${ }^{l}$ Steinhorn and Diggs-Brown relate the story of former United

States Assistant Attorney General Deval Patrick:

In a day in the life of two Americas, the mere prospect of hailing a cab, going to the store, eating at a restaurant, taking an elevator, or driving the interstate takes on entirely different meanings for Blacks and Whites. "I remember coming from a meeting with the president of the United States in the Oval Office, out on Pennsylvania Avenue one night and not being able to get a cab," says Patrick. "And I don't mean not getting a cab because it was raining and there were a lot of people competing. I mean cabs would fly by me but stop for the person who was dressed like me, someone standing down the street a ways, someone who was White." It is hard to find a Black person, especially a Black man, who has not experienced some variation on this theme.

Dent interviewed a number of African American middle and upper class Blacks from around the nation. ${ }^{3}$ Tatum describes the new sociological phenomena of Black middle class families in White middle class neighborhoods as "Assimilation Blues." 4 This passage by Mathis perhaps summarizes the feelings of many middle class Black Americans:

Like strangers, we are less at ease, transacting our daily lives with less true liberty, more trepidation, and in the face of more closed or stubborn doors than others who call America home. We are by no means newcomers, nor are our numbers so slight that the disparities can be excused as oversights. The original twenty have become thirty-five million souls. Most of us--91 percent--were born and have lived only here.

Still from time to time and in sundry ways, come signs that our presence is not welcomed. The United States of America may be our home and, as such, it deserves our duty - our productivity, patriotism and compliance. But it does not always feel like home. Not if home is where you let your hair down and kick your shoes off and help yourself to the bounty. Not if home is where you don't have to tiptoe or look

1 Deval Patrick, quoted in Steinhorn and Diggs-Brown, By the Color of Our Skin: The Illusion of Integration and the Reality of Race (New York: Penguin Press, 2000),

${ }^{2}$ Steinhorn and Diggs-Brown, 76.

${ }^{3}$ David J. Dent, In Search of Black America: Discovering the African-American Dream (New York: Simon and Schuster, 2000).

4 Tatum, 124-130. 
over your shoulder or wonder what they are saying about you or doing behind your back. Not if home is where there are no favorites, only equal kin. Not if home is where others care about you and wouldn't think of letting you go hungry or homeless, or ill-educated or without medical care, without nurturance of, or appreciation for, the gifts you bring and the talents with which you are endowed. Not if home is where you need not explain yourself as if you are some mystery created for intrigue or dissection - "a chronic patient for the sociological clinic, the sick man of American democracy,' as Black writer Alain Locke put it in 1925.'

\section{Cose's 1993 work, The Rage of the Privileged Class: Why Are Middle Class}

Blacks Angry? Why Should America Care? enlightened the nation to the feelings of the

Black middle class. Cose describes what he calls "a dozen demons" or psycho-social

stressors that are experienced by the Black middle class: (1) inability to fit in, (2)

exclusion from the club, (3) low expectations, (4) shattered hope, (5) faint praise,

(6) presumption of failure, (7) coping fatigue,(8) pigeonholing, (9) identity troubles,

(10) self-censorship, (11) mendacity, and (12) guilt by association. Cose warned

America not to trivialize or marginalize the troubling discontent and disaffection of the

Black middle class:

Formidable though the difficulties of the so-called underclass are, America can hardly afford to use the plight of the Black poor as an excuse for blinding itself to the difficulties of the Black upwardly mobile. For one thing, though the problems of the two classes are not altogether the same, they are in some respects linked. Moreover, one must at least consider the possibility that a nation which embitters those struggling hardest to believe in it and work within established systems is seriously undermining an effort to provide would-be hustlers and dope dealers with an attractive alternative to the streets. ${ }^{2}$

It is possible to wonder why the Black middle class should feel so disaffected and alienated from the mainstream of American society. After all, are they not the beneficiaries of affirmative action, and preferential treatment? While it is true that they

1 Deborah Mathis, Yet a Stranger: Why Black Americans Still Feel at Home (New York: Warner Books, 2002), 2.

${ }^{2}$ Ellis Cose, The Rage of the Privileged Class: Why Are Middle Class Blacks So Angry? Why Should America Care? (New York: Harper Collins, 1993), 8. 
have reaped the rewards of the civil rights movement, the gap between what is and what could or should be appears to be the source of the discontent.

\section{Summary}

The economic, educational, and social descriptors of the Black middle class presented here provide an ethnographic profile of the Black middle class. The data reveal (1) the Black middle class are generally college or technically educated and Black females are generally more educated than Black males; (2) their income is less than their Whites counterparts; (3) they possess less wealth than their White counterparts; (4) they have different financial strategies than their White counterparts; (5) they pay more to borrow money from secondary markets; (6) children of this class score lower on standardized tests than the children of the Black lower class; (7) Black females outpace Black males in the professional-managerial class.

These data reveal the significant economic, educational and political strides forward. However, it appears that the consistent and persistent pattern of discrimination in society has fostered a sense of alienation from the mainstream. For all the social, legal, and economic progress made by this group, there still appears to be a spiritual longing for something more.

If the church were successful in recruiting this class, then it must understand the sense of alienation, disaffection and the longings of the Black middle class. The felt needs of this class must be addressed with context specificity and sensitivity. What follows is a discussion of how these descriptors create challenges to ministry. 


\section{CHAPTER V}

\section{RESULTS OF SURVEY OF ATTITUDES, VALUES, AND PRIORITIES \\ OF THE BLACK MIDDLE CLASS IN SELECTION OF CHURCH}

This study has examined the historio-cultural framework of the Black middle

class. It has rehearsed the rise of this class and some of the challenges facing this class. The ethnographic profile has identified some of the felt needs of this class, and these felt needs may be used to inform general approaches to ministry. But, thus far, this study has not specifically asked 'what factors influence the Black middle class to join a church. In this section, the results of a survey of 177 Black middle class persons are presented to determine factors that influence their decision to attend or affiliate with a congregation.

\section{Results}

Survey results, reported as frequencies, are presented in six categories. They are: (1) factors which impact the Black middle class decisions to join a church, (2) desired emphases in the church, (3) most effective forms of evangelism, (4) most important worship elements, (5) most meaningful styles of worship, and (6) the role of the pastor. Data presented represent cumulative responses of "very important" and "essential" for each survey item. 
Factors Influencing Decisions to Join a Church

An overwhelming 90 percent of 177 respondents reported that "biblical

teachings" is the most important factor in selecting a church (see table 9). The

respondents were not asked which biblical teaching is most important, or whether the

absence of a particular biblical teaching would negatively influence their decision to join

a church. Only 35 percent of respondents reported that the attendance of friends, family

and neighbors was an important factor in selecting a church, while over 74 percent

reported that ministries sensitive to personal needs or concerns are important.

Thirty-seven percent indicate that the "nearest church in my denomination" would be an important factor in their decision to join a church. Twenty-five percent reported that the church nearest their home is an important factor in their decision to join a church.

TABLE 9 FACTORS THAT IMPACT DECISIONS
TO JOIN A CHURCH

\begin{tabular}{lc}
\hline \hline Factors & Percentage \\
\hline \hline Biblical teachings & 90.4 \\
Quality of sermons & 81.3 \\
Style of worship & 75.5 \\
Ministries sensitive to personal needs/concerns & 73.8 \\
Ministry/discipleship opportunities & 63.9 \\
Reputation or influence of the pastor & 61.2 \\
Reputation or influence of the church & 52.8 \\
Nearest church in my denomination & 37.0 \\
Family, friends or neighbors are members & 35.0 \\
Nearest church to my home & 25.0 \\
\hline \hline
\end{tabular}


Willingness to Join a Non-African-American Church

When asked "Would you consider joining a non-African-American church?" most respondents (73 percent) answered "definitely yes" or "would consider." Table 10 presents these results.

TABLE 10

JOIN A NON-AFRICAN-AMERICAN CHURCH?

\begin{tabular}{lcc}
\hline \hline Response & $N$ & Percentage \\
\hline \hline Definitely "no" & 49 & 27.7 \\
Definitely "yes" & 45 & 25.7 \\
Would consider & 83 & 46.9 \\
& & \\
\hline
\end{tabular}

Style of Worship

Seventy-five percent of respondents reported that the style of worship was an important factor in selecting a church. When asked about style of worship preferred, 46.1 percent reported "contemporary Christian" and nearly 44 percent reported traditional African-American (see table 11).

Cross-tabulations indicate that younger persons ages 21-35 were the most likely to indicate "Contemporary Christian" (56 percent). Only 29 percent of those persons ages 40-60 find "Contemporary Christian" meaningful and 0 percent of those over the age 60 find it meaningful. Twenty-three percent of 60 -year-olds preferred traditional Black "Pentecostal/Charismatic" style of worship. 
TABLE 11

STYLE OF WORSHIP

\begin{tabular}{ll}
\hline \hline Style & Percentage \\
\hline \hline Contemporary Christian & 46.1 \\
Conservative/Traditional African American & 43.8 \\
& 31.2 \\
Traditional/Mainline Protestant & 23.3 \\
Pentecostal/Charismatic & 11.1 \\
Catholic/Episcopal Liturgy & \\
\hline
\end{tabular}

Desired Emphases in the Church

Black middle class persons were surveyed to determine which ministry area they would desire to see the church give more emphasis. Table 12 lists their preferences in descending order.

Survey respondents desired the church to give more emphasis to issues related to family relationships and dynamics than any other area of emphases. Parenting ranked first with 81 percent of participants desiring that it have emphasis. Marriage support and counseling was second with 80 percent of respondents desiring the church to give it emphasis. It is interesting to note that although approximately 23 percent of all respondents were over the age of 46 years, nearly 68 percent of respondents indicated that "aging/senior issues" should be given emphasis in the church. Nearly 71 percent reported that "Support for families and children of incarcerated" was a very important or essential area of emphasis in the church. This study did not ask if the respondents had family members who were incarcerated. 
TABLE 12

DESIRED EMPHASES IN THE CHURCH

\begin{tabular}{ll}
\hline Area & Percentage \\
\hline \hline Parenting & 81.4 \\
Marriage Counseling \& Support & 80.2 \\
Homelessness/Hunger & 79.1 \\
African American Health Issues & 78.6 \\
Substance Use \& Abuse & 75.7 \\
AlDS & 75.1 \\
Teen Pregnancy & 75.2 \\
Personal Finance & 71.2 \\
Sexuality & 70.6 \\
Support of Families and Children of & \\
$\quad$ Incarcerated Persons & 70.6 \\
Aging/Senior Issues & 67.8 \\
Educational Opportunities \& Advancement & 66.6 \\
Career Development/Job Placement & 63.2 \\
Singleness & 62.1 \\
Racial Concerns & 58.2 \\
Political Issues (Voting/Civil Rights) & 54.8 \\
\hline \hline
\end{tabular}

Health issues were indicated as important areas for emphasis in the church. Seventy-nine percent would like for their church to give more emphasis to issues of African-American health. Substance use and abuse ranked fourth overall, with over 76 percent identifying it as needing emphasis in the church. Seventy-five percent desired to see more emphasis on AIDS, although the survey did not ascertain whether that emphasis should be in the form of education, health care or advocacy.

The most pressing social issue expressed by this sample population was "homelessness/hunger" which tied with "marriage counseling and support" for second highest of the fourteen areas of emphasis with 79 percent. This is interesting since 52 percent of the total respondents are home owners and as a cohort, given their income and 
education, they are not likely to become homeless. Whether their response can be read as genuine concern for the homeless or a fear that they are vulnerable to fluctuations in the economy is grounds for further research.

Ranking last in importance of desired emphasis were the areas "racial concerns," ranked 13 of 14 indicators with nearly 59 percent responding, and "political issues," ranked last with 55 percent responding. It should be noted that numbers indicate there is still a major concern with over half of respondents expressing a desire to see those issues given emphasis.

\section{Emphasis by Education}

Sixty-seven percent of respondents reported that "educational opportunities and advancement" were "very important" or "essential" areas of emphasis for the church; it ranked $10^{\text {th }}$ out of the 14 areas of emphasis. This may be explained by the fact that 43 percent of all respondents hold a graduate degree or professional certification and another nearly 35 percent have attended college. These data indicate that education is important to this class of people, but they do not look to the church to support or provide primary educational needs. Those with lower incomes more often than not expressed a desire for the church to be involved in education. My study indicates that 80 percent of those with trade school or technical education reported that the church needs to emphasize educational opportunity, while only 64 percent of those with graduate or professional degrees reported that the church needs to emphasize this area more (see table 13). 
TABLE 13

EDUCATION BY SELECTED EMPHASES

\begin{tabular}{llll}
\hline \hline $\begin{array}{l}\text { Level of } \\
\text { Education }\end{array}$ & $\begin{array}{l}\text { Educational } \\
\text { Opportunity }\end{array}$ & $\begin{array}{l}\text { Career } \\
\text { Development }\end{array}$ & $\begin{array}{l}\text { Personal } \\
\text { Finance }\end{array}$ \\
\hline \hline Some high school & .57 & .57 & .57 \\
High school graduate & .65 & .74 & .78 \\
$\begin{array}{l}\text { Trade or technical } \\
\text { school }\end{array}$ & .80 & .80 & .70 \\
Attended college & .69 & .96 & .69 \\
Graduate school & .64 & .59 & .72 \\
\hline
\end{tabular}

Those with a trade or technical education are more likely than the lesser educated to believe that "career development" should be given emphasis in the church $(80$ percent). Only 68 percent of those who had attended college and 64 percent of those who hold a graduate degree or professional certification believed "career development" to be an important or essential area of emphasis, compared with 73 percent of individuals with a high-school education. Education is not the only distinguishing marker in terms of response to this question. Cross tabulations reveal that 91 percent of those earning $\$ 50,000-\$ 70,000$ deemed "career development" important or essential.

Overall, 71 percent of the 177 respondents deemed "personal finance" an important or essential area of emphasis for the church. Not surprisingly, cross tabulations indicate that those with high-school education considered it more important than those who have attended college--78 percent and 68 percent respectively. Seventy-two percent of persons holding a graduate degree or professional certification report "personal finance" as an area needing emphasis. 


\section{Preferred Forms of Evangelism}

Participants were asked, "What form of evangelism is most effective?" They were permitted to respond to more than one form of evangelism; data below represent those who responded Very Important or Essential to the category listed (see table 14). Seventy-three percent of respondents indicated that "one-on-one Bible study" is the most effective. Thirty-five percent of respondents deemed "tent meetings" as being the least effective form of evangelism. This does not mean that they consider it to be ineffective, rather just the least effective for winning persons similar to themselves. The study reveals that the Black middle class desire personal contact in evangelistic efforts with "one-onone-Bible study" ranked first in effectiveness, and "small group evangelism" ranking third, with 60 percent of participants responding favorably. Mass media evangelism via television, radio, and newspapers ranked as the fourth most effective form of evangelism, with 57 percent responding favorably.

TABLE 14

MOST EFFECTIVE FORMS OF EVANGELISM

\begin{tabular}{lc}
\hline Form & Percentage \\
\hline \hline One-on-one Bible Study & 73.5 \\
Church Revival & 66.1 \\
Small Group Evangelism & 60.4 \\
Mass Media (Television, radio, newspaper ads) & 57.3 \\
Lifestyle Evangelism & 56.5 \\
Special Events (programs, concerts, Christmas play, etc.) & 56.2 \\
Prophecy Seminars & 49.7 \\
Tent Meeting & 35.0 \\
\hline \hline
\end{tabular}




\section{Most Important Worship Elements}

The participants were asked, "What elements are most important to you in worship services?" Respondents were allowed to respond to more than one worship element. Percentages in table 15 represent composite answers.

Biblical content was reported to be the most important element in worship: more than the ability of the preacher, or music, both considered staples in African-American worship.

TABLE 15

MOST IMPORTANT WORSHIP ELEMENTS

\begin{tabular}{ll}
\hline Elements & Percentage \\
\hline & \\
Biblical Content & 91.7 \\
Prayer & 81.7 \\
Ability of the Preacher & 80.0 \\
Participation of Worshippers & 73.9 \\
Music & 68.9 \\
\hline
\end{tabular}

The Role of the Pastor

Those surveyed were asked, "What is the role of the pastor?" Table 16 presents the findings. The majority of respondents believe the role of the pastor is that of counselor and spiritual advisor, interpreter of the word, and worship leader. More than 56 percent think the role of the pastor involves community activism. 
TABLE 16

ROLE OF THE PASTOR

\begin{tabular}{ll}
\hline Role & Percentage \\
\hline & \\
Counselor/Spiritual Advisor & 81.7 \\
Interpreter of the Word & 79.4 \\
Worship Leader & 76.1 \\
Community Activist & 56.7 \\
\hline \hline
\end{tabular}

\section{Responses to Survey and Church-Growth Principles}

How do the responses of the Black middle class compare with the growth principles as identified by Barna/Jackson and Schwarz? Although the terms used are not the same, the concepts are similar (see table 17). One will notice particularly the overlap of items in some areas. For example, Schwarz's concept of holistic small groups is larger than the survey response of small-group evangelism. Schwarz sees small groups as nurturing support, evangelistic, and discipleship groups. What is reported here is not an attempt to provide a complete correlation of terms or concepts, but rather to illustrate complementary concepts. 
TABLE 17

BARNA/JACKSON AND SCHWARZ COMPARED: SELECTED FACTORS THAT INFLUENCE CHURCH AFFILIATION

\begin{tabular}{|c|c|c|c|}
\hline $\begin{array}{l}\text { Barna and Jackson Term or } \\
\text { Concept }\end{array}$ & $\begin{array}{l}\text { Schwartz Term or } \\
\text { Concept }\end{array}$ & $\begin{array}{l}\text { Factor Identified } \\
\text { by Black Middle Class }\end{array}$ & Percentage \\
\hline $\begin{array}{l}\text { Leadership ( successful } \\
\text { leadership in the Black } \\
\text { Church) } \\
\text { - pastor as change agent } \\
\text { - communication that } \\
\text { inspires } \\
\text { - leadership in the team } \\
\text { context } \\
\text { - refusal to micromanage } \\
\text { - investment in } \\
\text { developing followers } \\
\text { impact through } \\
\text { collaboration }\end{array}$ & $\begin{array}{l}\text { Empowering } \\
\text { leadership. } \\
\text { Functional } \\
\text { Structures. }\end{array}$ & $\begin{array}{ll} & \text { Pastor as Counselor/ } \\
\text { advisor } \\
\text { - } \\
\text { Ministry/discipleship } \\
\text { opportunities }\end{array}$ & $\begin{array}{l}82 \\
74\end{array}$ \\
\hline Discipleship & $\begin{array}{l}\text { Holistic small } \\
\text { groups }\end{array}$ & $\begin{array}{l}\text { Ministry/discipleship } \\
\text { opportunities } \\
\text { - Small group evangelism }\end{array}$ & $\begin{array}{l}74 \\
60\end{array}$ \\
\hline Worship & $\begin{array}{l}\text { Inspiring worship. } \\
\text { Passionate } \\
\text { spirituality }\end{array}$ & $\begin{array}{ll}\text { - } & \text { Biblical content } \\
\text { - } & \text { Prayer } \\
\text { - } & \text { Ability of preacher } \\
\text { - Participation } \\
\text { - } \\
\text { Music }\end{array}$ & $\begin{array}{l}92 \\
82 \\
80 \\
74 \\
69\end{array}$ \\
\hline Evangelism & $\begin{array}{l}\text { Need-oriented } \\
\text { evangelism. }\end{array}$ & $\begin{array}{ll}\text { - } & \text { Ministry sensitive to needs } \\
\text { - } & \text { One on one Bible study } \\
\text { Lifestyle evangelism }\end{array}$ & $\begin{array}{l}74 \\
74 \\
56\end{array}$ \\
\hline Family & $\begin{array}{l}\text { Holistic small } \\
\text { groups. }\end{array}$ & - Small group evangelism & 60 \\
\hline Stewardship & & - $\quad$ Personal finance & 71 \\
\hline Community & & $\begin{array}{l}\text { - } \quad \text { Pastor as activist } \\
\text { - } \quad \text { Racial concerns } \\
\text { - }\end{array}$ & $\begin{array}{l}57 \\
58 \\
55\end{array}$ \\
\hline Relationships and family & $\begin{array}{l}\text { Loving } \\
\text { relationships. }\end{array}$ & $\begin{array}{ll}\text { - } & \text { Parenting } \\
\text { - } & \text { Marriage support } \\
\text { - } & \text { Family friends are } \\
\text { members } \\
\text { - }\end{array}$ & $\begin{array}{l}81 \\
80 \\
35 \\
68\end{array}$ \\
\hline
\end{tabular}

Source: George Barna and Harry R. Jackson, High Impact African American Churches: Leadership Concepts from Today's Most Effective Churches (Ventura, CA: Regal, 2004), Christian A. Schwarz, Natural Church Development: A Guide to Eight Essential Qualities of Healthy Churches (Carol Stream, IL: Church Smart Resources, 1998), and results from Survey of Black Middle Class (this document). 


\section{CHAPTER VI}

\section{THEORETICAL FRAMEWORKS THAT INFORM APPROACHES TO THE BLACK MIDDLE CLASS}

The study thus far has examined some of the major social descriptors in an ethnographic profile and, from it, felt needs have been a The factors which influence the Black middle class have been surveyed and specific felt needs have been identified. How then shall the practitioner of ministry proceed with the creation of ministry? What theoretical frameworks should inform ministry approaches to the Black middle class in churches in transition?

This section examines three theoretical frameworks and their implications for ministry to the Black middle class. First, social theory approaches, which are primarily descriptive and seek a framework for understanding the phenomena of the Black middle class, will be discussed. Questions about the relevancy of utilizing secular theories to apply to a ecclesiastical dilemma will be considered. The missiologic approach, which applies principles of missions to the winning of the Black middle class, will be discussed. Finally, the church growth movement approach, in particular, the "homogenous unit principle" as applied to the American church context will be discussed. The appropriateness of its application to the challenge of ministry to the Black middle class will be examined. Conclusions drawn from each of these theories will inform approaches to ministry to the Black middle class. 


\section{Social Theory and the Study of the Black Middle Class}

There are three basic social research frameworks that have been applied to the study of the Black family and Black people in America. They are the cultural deviant theory, the cultural equivalent theory, and the cultural variant theory.

The cultural deviant theory suggests that Black families are different from White families in negative and potentially destructive ways. This theory presupposes a cultural norm based upon Eurocentric standards and then postulates that those who do not meet that standard are in some way deviant from the norm. Two examples of this theory may be seen in the work of Billingsly and Allen. ${ }^{1}$

The challenge of this theory if applied by a church, at least from a theological perspective, is that it assumes the superiority of the European culture, which results in the divinization of one group. ${ }^{2}$ The Bible teaches that all cultures are fallen, all are deviant, and "all have sinned and come short of the glory of God" (Rom 3:23). Comparing one fallen culture to another is like the alcoholic saying to the crack addict, "Well, at least I'm not a crack addict."

If the cultural deviant theory were applied to the recruitment of the Black middle class it would require the renunciation of Black cultural norms in favor of Eurocentric norms. It would assume that Black culture is more fallen than White culture, and Black culture could not be used as a legitimate vehicle for the communication of the gospel.

${ }^{1}$ Tatum discusses the three social theories in her work Assimilation Blues. For a fuller explanation of Billingsly, see Climbing Jacobs Ladder: The Enduring Legacy of African American Families (1992).

${ }^{2}$ Leslie M. Pollard, "Leaders; Race and Ethnicity: Temple or Vehicle" in Embracing Diversity: How to Understand and Reach People of All Cultures (2000), 16. 
The second social theory, cultural equivalent theory, purports that Black families are essentially the same as White families, with the effects of social class accounting for the apparent differences. ${ }^{1}$ If this theory held true, then the White middle class and the Black middle class would be essentially the same, holding all things in common including values, customs, rituals, religion, and worldview. However, research seems to indicate otherwise. $^{2}$

Unfortunately, a common mistake made in the construction of ministry programs and social interventions is the assumption that Black middle class persons are the same [as Whites ?] except for the color of their skin. This ethno-relative perspective may promote tolerance, openness and dialogue by leveling the cultural playing field, but it fails to recognize the fallenness of all cultures. It also fails to address the specific fallen aspects of a culture. ${ }^{3}$ For example it may consider polygamy and pair-bond marriage as equally valid depending upon its cultural context. Ethno-relativity does not offer a critical critique of culture.

The third social theory, cultural variant theory, posits that the "Black family is culturally distinctive due to its particular historical and socio-cultural context, but does not assume those distinctions to be necessarily pathological." This theory is closer to anthropological and missiological approaches, which allow for people to be viewed,

\footnotetext{
${ }^{1}$ For an example of this theory, see J. Scanzoni, "Sex Roles, Economic Factors, and Marital Solidarity in Black and Whites Marriages," Journal of Marriage and Family 37, no. 1 (1975), 130-144.

${ }^{2}$ For an example of research that contradicts the Cultural Equivalent Theory, see R. Staples, "Race, Liberalism, Conservatism, and Pre-marital Sexual Permissiveness: A Bi-racial Comparison," Journal of Marriage and Family 40, no.4 (1978), 733-742.

${ }^{3}$ Pollard, "Leaders, Race and Ethnicity: Temple or Vehicle?" 17.

${ }^{4}$ Tatum, $1,2$.
} 
evaluated, and approached within their own cultural context. ${ }^{1}$ Taking a culturally variant approach to the Black middle class allows one to ask, "What makes the Black middle class different from its White counterpart?" "What are the strengths and weaknesses of this class?" "What cultural particulars will impact approaches to this class?" If the gospel is to go to every class then we must examine not only the particular characteristics of the group, but the best methodologies for reaching them.

Of the three social theories, the cultural variant theory appears to provide a better framework for understanding the Black middle class. It examines the Black middle class in context. But simply providing understanding does not provide the most useful framework for ministry. Ministry, in the Christian sense involves more than the amelioration of the effects of social forces on the lives of individuals. Christian ministry sees the individual in the larger context of the biblical cosmic view of salvation history. In that view, sin and the consequences of $\sin$ are the ultimate forces with which one must grapple, and ultimate deliverance from the condition of $\sin$ is the goal, not just palliative care to ameliorate its effects.

\section{Missions Theory Applied to the Study of the Black Middle Class}

Missiology is the study of Christian evangelistic enterprise to various cultures. It is concerned with the cross-cultural communication of the gospel of Christ. Missiology first affirms the "Great Commission" of Christ found in Matt 28 to "go make disciples of all peoples by baptizing them in the name of the Father, and the Son and the Holy Spirit" (Matt 28:18-20). Second, missiology applies a cultural variant approach in that it recognizes that cultural differences exist. People are not all the same. Christ command

\footnotetext{
${ }^{1}$ Paul G. Hiebert, Anthropological Insights for Missionaries.
} 
"Go make disciples of all people" or " $\varepsilon \theta v \varphi$," meaning every ethnic group. Therefore, missiology affirms that anthropology is important to unpack the meaning of a particular culture. Third, missiology affirms that while the core of the Christian remains indissoluble, the method by which it is being communicated must be context specific. Anthropology does not inform theology; rather, anthropology informs methodology. Fourth, missiology affirms that proper methodology grounded in proper theology and informed by good anthropology will result in the building of bridges between cultures for the transmission of the gospel.

David Hesselgrave, missiologist, unpacks the relationship between anthropology, theology, and methodology in his book Communicating Christ Cross-Culturally.' Using cross-cultural communication as the theme of his work, he examines the subject through the lens of the missiologic enterprise. In describing dimensions of cross-cultural communication he lists the following. First, worldviews, general frames of perceiving and interpreting the world, must be taken into consideration. Second, cognitive process or the way in which people think must be accounted. Third, linguistic forms or ways of expressing ideas in word symbols vary from culture to culture. In the late twentieth century, the word "bad" meant "good" in the urban context; but it meant just the opposite in the larger society. Fourth, behavioral patterns or ways of acting vary from culture to culture. Fifth, social structures or ways of interacting are important. Sixth, media influence or ways of channeling the message vary. Finally, motivational resources or ways of deciding must be taken into consideration. ${ }^{2}$

\footnotetext{
${ }^{1}$ David J. Hesselgrave, Communicating Christ Cross-Culturally: An Introduction to Missionary Communicatio, 2nd ed. (Grand Rapids, Ml: Zondervan, 1990).

${ }^{2}$ lbid., 192.
} 
If the goal of mission is to communicate the gospel cross-culturally, then what distorts, inhibits, interferes, or prevents the effective communication of the gospel to the Black middle class? Given the fact that Blacks and Whites, wealthy and poor in the United States all share certain commonalities of the larger American culture, what possible barriers may race or class play in communicating the gospel? How does ethnicity and class affect the seven dimensions of cross-cultural communication? Here, anthropology may give us insights as to our methodology.

Some might argue that looking at the Black middle class through missiological principles is a misapplication of those principles. But to look at the Black middle class through missiological principles is extremely important. After all, mission principles were developed to describe how to interact with and bring the gospel to those of a foreign culture. Because of the historic affiliation with Christianity, it may be argued that Black middle class Americans are neither heathen nor of a foreign culture, and therefore the application of missions theory is inappropriate.

However, while it is certainly true that African-American culture has been closely associated with the Black church, to assume that all Blacks are therefore Christians is as flawed as assuming that all Italians are Catholic. In addition, it is unwise to assume that the American culture is one monolith. Given that these assumptions are flawed, it is worth the examination of missiological principles for those Black middle class persons who are neither Christian nor have been able to hear the gospel expressed through a cultural idiom familiar to them. The Black middle class may represent a society within the larger society. 
"A society," remarks Heibert, "is made up of people, but it is not defined by merely the number of individuals it contains. Members of a "society" form a social organization, a patterned way of relating to one another. They occupy a set of socially defined positions and interrelate in ways appropriate to that arrangement."' The challenge of race and class in the United States is that it has often defined positions and prescribed ways of relating to one another. Whites and the wealthy, by virtue of skin color and assets, have traditionally assigned a different status than non-Whites and those of lesser means. This is called "ascribed status" given on the basis of inherent characteristics, such as ethnicity, gender, family background, and class. "Others, which we call "achieved statuses" (i.e., student, doctor, or missionary), must be earned."2

Skin color is an ascribed status. White skin has historically functioned as the prerequisite for full enfranchisement into the American social, political, and economic mainstream. Conversely, Black skin has been the visible indicator of society's right to exclude. ${ }^{3}$ Skin color has historically locked the two races into fixed roles: the dominator and the dominated, the oppressor and the oppressed, the victor and the victim, the powerful and the powerless. Identity and self-worth have been caught up into one's status and roles.

Status and roles have shaped different worldviews of individuals living in the same society. Whites have been socialized to believe that power may be earned or

\footnotetext{
${ }^{1}$ Hiebert, Anthropological Insights, 256.

2. Ibid.

3 For a discussion on skin color and privilege see F. James Davis, Who Is Black: One Nation's Definition (University Park, PA: The Pennsylvania State University Press, 1991), and also Charshee McIntyre, The Criminalization of a Race: Free Blacks During Slavery (Queens, NY: Kayode Publications,
} 1992). 
power must be protected. ${ }^{1}$ Blacks have come to believe that power must be gained or seized. Whites have been socialized to believe that merit receives just recompense. Blacks have come to believe that "a Black person must be twice as good to go half as far." ${ }^{2}$ Some Whites are fearful that affirmative action has weakened the so-called meritocracy ${ }^{3}$ while some Blacks believe that affirmative action is a step toward the reversal of years of racial exclusion and a necessary step if a true meritocracy is ever to exist. These are two fundamentally different world views influenced by race and class.

Because of the ethnic division, inter-ethnic relations have been hampered by the cultural particularities born of that separation. Blacks, having been an excluded class by both ethnicity and class, developed a subculture with its own linguistic forms (Black English), and behavioral patterns (signifying). Blacks, socialized in the sub-culture and coming into contact with the behavioral and linguistic norms of the larger society, often have difficulty accepting those norms and being accepted by those norms. For example, Black students, who are fluent in and even creatively brilliant in their cultural dialect, will find great difficulty if they attempt to demonstrate that proficiency in the Standard English language classroom.

\footnotetext{
${ }^{1}$ The concept of "Whiteness" is described in terms of White identity, racial politics of "Whiteness", White privilege, White pedagogy, and the implications of "Whiteness" in culture and education. See White Reign: Deploying Whiteness in America, Joe I. Kinchelo, Shirley R. Steinberg, Nelson M. Rodriguez, and Ronald E. Chennault, eds. (New York: St. Martin's Press, 1998).

${ }^{2}$ This is a common colloquialism in the African-American community used by parents to urge their children toward academic accomplishment.

${ }^{3}$ See Patrick Buchanan's treatment of the subject of the impact of declining White birthrates and the impact of immigration and affirmative action. Patrick Buchanan, The Death of the West: How Dying Populations and Immigration Invasions Imperil Our Country and Civilization (New York: Thomas Dunne Books, 2002). Belief in meritocracy is not exclusive to White persons. See Stephen L. Carter, Reflections of an Affirmative Action Baby (New York: Basic Books, 1991), and Shelby Steele, The Content of Our Character: A New Vision of Race in America (New York: Harper Collins, 1990).
} 
Researchers in the field of education have discovered that reading material reflective of the student's culture assists the student in making meaning of the text.' A sociological contextualization of the subject makes it accessible to the reader. So also, the missioloigist would argue that a contexualization of the gospel assists the convert in making meaning of the gospel by removing foreign, culturally-ladened noise from the communication process.

But contextualization has it pitfalls as well. Heibert points out that an uncritical acceptance of the culture that one is trying to win, may inadvertently lead to syncretism. ${ }^{2}$ Too much cultural particularity may water down the gospel and its meanings, and symbols may be swallowed up into that of the culture without critique. Blind contextualization may ghettoize the gospel into culture. Conversely, not to contextualize the gospel runs the risk of the gospel not being understood, or it being outright rejected. How much contextualization is too much, versus how much is enough? This is a debate that is currently being waged in the church-growth movement, which will be discussed below.

Since the historic strides have been made to abolish racism in America, those formerly locked into roles are now finding that they must adjust to new roles. Blacks and Whites now may share the same economic class because of achieved status, but to break out of traditionally ascribed status roles may prove challenging. For instance, it may prove difficult for a White person, born into a sense of entitlement by virtue of skin color, to view a Black person as a true equal. Also it may be challenging for a person born into

1 Elfreda V. Blue, "How Middle School Students with Learning Disabilities Read and Respond to Literary Text" (Ph.D. dissertation, State University of New York at Buffalo, 1998).

${ }^{2}$ Hiebert, Anthropological Insights, 184-186. 
a lower class status to decipher the symbols and meanings of her new class, thus preventing her from navigating through and assimilating into her new class.

The missiological approach to this dilemma would be first to assess the amount of cultural distance between the two cultures. ${ }^{1}$ Second, the task would be to build a cultural bridge between the two cultures thereby creating a new supra-culture. ${ }^{2}$ To do this would require a reframing of the gospel to speak to the persons in their particular context and to call them from the exclusivity of their culture-bound roles and statuses and into unity in the body of Christ.

\section{Homogeneity versus Heterogeneity:}

\section{Church Growth Principles}

Contextualization creates a tension between cultural particularity and biblical universality. Are the two mutually exclusive? The modern American Church Growth Movement has been wrestling with this tension for a number of years. Donald A. McGavran is considered to be the father of the modern American church-growth movement. Born in India to missionary parents, he completed his study in the United States and returned to India as a missionary in $1923 .^{3}$ He studied 145 mission stations over seventeen years and began to extrapolate pragmatic principles of cross-cultural evangelism which he published in his first book in 1955, The Bridges of God. McGavran came to believe that effective numerical evangelism is best accomplished when the evangelist is of the same culture, class, tribe or family as the person whom he is trying to

\footnotetext{
${ }^{1}$ Hesselgrave, 169.

${ }^{2}$ Hiebert, Anthropological Insights, 216.

${ }^{3}$ Kirk Wellum, "An Evaluation of the Church Growth Movement” http://www.xcelo.onca/ $\sim$ sgcc/ cgm.htm (Accessed 18 January 2005).
} 
evangelize. ${ }^{1}$ He codified this pragmatic method into what has come to be universally known as "the homogenous unit principle". The "homogenous unit principle" is "the belief that men and women in different homogenous units or groups prefer to become Christians without crossing racial, linguistic, or class barriers."

McGavran's principles, originally designed for the foreign mission field, were later applied to church growth in America. In 1965 Fuller Theological Seminary founded the Fuller School for World Missions with McGavran as its head. Fuller Theological Seminary would prove to be the incubator for the church-growth movement producing such notable disciples as Winfield Arn, the founder of the American Church Growth Institute, and C. Peter Wagner, the most prolific author and spokesmen for the movement.

While missiology describes the culturally specific approach to evangelism as contextualization, the Church-Growth Movement has sought program contextualization through the use of various techniques. The "homogenous unit principle" is the vocabulary of the Church Growth Movement to describe a specific form of contextualization for the purpose of evangelism. For example, if the "homogenous unit principle" is the most effective means of evangelism, then the purveyors of church growth conclude that utilizing demographics to identify homogenous groups and utilizing marketing techniques to reach them would constitute the most effective means of evangelism. McGavran and Arn speak of "discerning the community," meaning, "seeing a church's ministry area in its sociological, economic, and ethnic composition and

\footnotetext{
'Ibid., 2.
} 
obtaining and analyzing information about it."2 Since the goal of the Church-Growth Movement is numerical acquisition, then it advocates "soil testing" research to discover which communities are most receptive to the Gospel and thus offer greatest potential. ${ }^{3}$ This approach is synonymous with that of George Barna, who borrowed directly from the world of business advocates using the four P's of marketing, (product, price, place, promotion) for marketing the gospel. ${ }^{4}$ The marketing approach has led to the development of "seeker services" or worship services designed to cater to the needs of the segment of the market that has been targeted. "User Friendly Churches" seek to eliminate as many barriers and impediments as possible so that the seeker may become a disciple. $^{5}$

This evangelistic pragmatism has come under scrutiny and has been open to criticism. Pastor Kirk Wellum attacks the pragmatic principle of interpretation that is used to determine which biblical passages and doctrine receive the greatest attention. "Several analysts have pointed out that this hermeneutic opens the door for a new kind of liberalism in which "the world sets the agenda for the church." "Some wonder if seeker

' Donald A. McGavran, Understanding Church Growth (Grand Rapids, MI: William B. Eerdmans, 1970), 223.

${ }^{2}$ Donald A. McGavran and Winfield C. Arn, Ten Steps for Church Growth (San Francisco, CA: Harper and Row, 1977), 127-130.

3 "Project Wittenberg: Evangelism and Church Growth with Special Reference to the Church Growth Movement," A Report to the Commission on Theology and Church Relations of the Lutheran Church-Missouri Synod, September 1987. 1992), 24.

${ }^{4}$ George Barna, Church Marketing: Breaking Ground for the Harvest (Ventura, CA: Regal Books,

${ }^{5}$ George Barna, User Friendly Churches: What Christians Need to Know About the Churches People Love to Go to (Ventura, CA: Regal Books, 1991).

${ }^{6}$ Wellum, web resource. 
services invert the meaning of worship by shifting the emphasis of worship away from God to felt needs of the person who is supposed to be worshiping. Some wonder whether the use of social science and marketing techniques has replaced the centrality of the Word of God and the sovereign operation of the Holy Spirit. McArthur, noted Christian apologist, argues:

Contemporary evangelism has been beguiled and sabotaged by a ruinous lack of confidence in God's word. They have accepted the notion that the scripture does not contain all that we need to minister in these complex times. So they turn to human enterprise in the fields of psychology, business, government, politics, entertainment, or whatever they think might supply some recipe for success that's lacking in scripture. ${ }^{1}$

Many ask, "If McGavran's "homogenous unit principle" teaches that people best come to Christ without crossing ethnic, linguistic and class barriers, then is not that movement promoting racism, classicism, and disunity in the church?"' Indeed, it may be argued that the closet racist, elitist, sexist, or bigot can easily hide behind the cloak of the "homogenous unit principle"--refusing to reach out to those unlike him/herself (supposedly for the greater good of church growth). One can argue that although the explicit goal of the application of "homogenous unit principle" is not intentionally racist or elitist, the end result may indeed foster such. Raleigh Washington adds:

We unwittingly provide a sanctuary for the people in the pews in which they never confront the reality they see as they leave the front door of the church. Even more so, we could well be co-conspirators to a subtle form of racism. To be sure, it is not purposeful, intentional racism, but a passive acquiescence for the great divide that exist between the races on Sunday. ${ }^{2}$

\footnotetext{
'John McArthur, Christ Our Sufficiency (Dallas: Word, 1991), 17.

${ }^{2}$ Raleigh B. Washington, "The Alternative to Ethnic-Focused Church Planting: How Can We Build Diversity as We Build Churches?" in Building Unity in the Church of the New Millennium, ed. Dwight Perry (Chicago: Moody Press, 2002), 112, 113.
} 
Rod Cooper writes, “A final implication [of the homogenous unit principle] ${ }^{l}$ is that in pursuing one particular ethnic or socio-cultural group there is a subtle message that those not 'like us' are not welcome here. As a result of such emphasis, racism and classism can subtly be propagated in the name of evangelism." " Evangelism is not exclusively to one group," says Cooper, "but to all groups regardless of economic categories, ethnic roots, cultural distinctiveness, or socioeconomic status. Each group helps make up the vast mosaic of the body of Christ."." Commenting on the pitfalls of homogeneity, Raleigh Washington pens, "Perhaps our measure of success should no longer rest upon the people being won to Christ, but the diversity of the group into which they are being won."

But the question remains, how then shall we approach the Black middle class? If we adhere to the homogenous unit principle, then it is possible for cultural particularity to degenerate into cultural exclusivity. It is possible to sacrifice unity in the name of diversity. The homogenous unit principle may lock some folk out of "koinonia" (fellowship) and lock others into a distorted and perverted version of "koinonia." But if we fail to recognize the uniqueness of cultural particularities, then we may, in effect, fail to communicate the gospel in a fashion that is meaningful to the hearer.

\footnotetext{
${ }^{1}$ Emphasis mine.

${ }^{2}$ Rod Cooper, "People Just Like Me: Does the Bible Give Us Freedom to Build Deliberately Homogenous Churches," in Building Unity in the Church of the New Millennium, ed. Dwight Perry (Chicago: Moody Press, 2002), 163.

${ }^{3}$ Ibid., 162.

${ }^{4}$ Raleigh Washington, 114.
} 
The Lutheran Synod also grappled with the issues at hand and reached the following conclusion:

The homogenous unit principle is considered by some to be one of the Church Growth Movement's most valuable contributions to evangelism. It holds that the Gospel is most effectively communicated within cultural units, among people who have the same cultural background, who speak the same language.

Some argue against this principle on the grounds that it appears to be racist or separatistic along cultural lines and therefore contrary to what Scriptures teach regarding the unity of the body of Christ. Others have found it to be very useful in mission outreach, provided it is not carried to extreme.

Uncritical acceptance and use of the homogenous unit principle may cause the church to lose sight of the important fact that the Gospel is the power of God for salvation, capable of reaching across cultural barriers to convert the lost. The Book of Acts demonstrates how a Jew named Paul, under the direction of the Holy Spirit, could proclaim the Gospel of reconciliation successfully to a Gentile world made up of different cultures, races, and peoples."

The Lutheran statement does not ignore cultural particularities, neither does it exalt them. Rather the statement argues against extremes. The extreme of ignoring culture can lead to ignoring the call to mission. The extreme of accepting the homogeneous unit principle uncritically can lead to failure to recognize the centrality of the Word and the operation of the Spirit in evangelism, relying instead on humanly constructed formulaic equations.

This study notes that the Church finds itself in a strange paradox. The Church is called to reach every nation, kindred, tongue and people, and so it must recognize the unique needs of the particular people, ethnicities and classes. The needs of a homeless man in Chicago in winter will be different from that of a corporate magnate on the West Coast in summer. Class and cultural differences must be given some consideration. It will influence the method of approach. Yet, neither culture nor class can ever be the

\footnotetext{
${ }^{1}$ Project Wittenberg, 8.
} 
determinant of status in the Church or the criteria by which one is excluded from the Church. The Church must be sensitive to culture without being bound by it.

\section{Summary}

Thus, which theoretical frameworks should inform ministry approaches to the Black middle class? First, sociological theory and anthropology alone cannot provide insights for church growth. The cultural equivalent theory does not take into consideration the uniqueness of the Black middle class, and therefore ministry grounded in this theory would simply resemble what already exists in churches in transition. The cultural deviant theory approaches the Black middle class as a social pathology to be corrected rather than a people group in need of ministry. The cultural variant theory, while seeing the Black middle class in context, neglects to see the sin context and the role of sin and salvation in shaping ministry interventions.

Second, missiology informed by theology offers legitimate methodology only valid if it arises out of solid theology. Missiology does take into account cultural particularities. Missiology does make use of the social sciences in developing ministry approaches.

Third, the homogenous unit principle makes careful examination of cultural particularities, but has the tendency to exalt methodology at the expense of good ecclesiology. The homogenous unit principle may foster separate but equal church ministries. This principle may provide an approach to those Black middle class desiring to stay within the confines of the familiar. However, the challenge facing both the church in transition and the Black middle class person in transition is that neither has the luxury 
to remain in the realm of the familiar. Social forces are demanding new paradigms that will facilitate ministry and integration into the body.

Churches in transition must therefore grapple with cultural particularities without being bound by them. In order for theory to be translated into good practice in the church, the theory must not only acknowledge and rightly interpret the reality of the present human condition, but it must also point toward God's ideal for a redeemed humanity. Because churches are ecclesiastical bodies and not secular institutions, then churches in transition must first look to the principles of the Word of God and test every other principle by the divine standard. 


\section{CHAPTER VII}

\section{THEOLOGICAL IMPLICATIONS OF CLASS AND ETHNICITY UPON MINISTRY TO THE BLACK MIDDLE CLASS}

This study has examine the social forces impacting the Black middle class, the expressed felt needs of this population, and various theories that may inform ministry approaches to this class. It has been noted that secular theories, while providing insight fall short in the development of ministry. Further, it has been concluded that missions theory and church growth theory, in particular homogeneity, are helpful but could be hurtful if not counterbalanced with good theology.

This section shall examine the theological implications of class and ethnicity upon praxis, mission and ecclesiology. This chapter examines how the early Church dealt with the issues of class and race in the Book of Acts. It will also explore issues of class and classism in the Epistle of James. This chapter includes a study of the Christ imperative found in John 17. Consideration will be given to the writings of Ellen White in regard to her statements to the Seventh-day Adventist Church on the subject of race and class.

\section{Status and Class in the Book of Acts}

Status and class in the Book of Acts cannot be viewed in a social vacuum. It existed against a historio-cultural context of the ancient Roman world. In the Roman Empire people were divided into rather rigid and immobile social classes. Status may 
change over time based upon wealth and, to a lesser degree, education. But status generally allowed one to rise within one's class, not to leave it. Birth determined one's class and persons were forbidden to marry outside of their class. ${ }^{1}$ As in many societies, land ownership and wealth also determined class. Only a very small percentage of the population controlled most of the wealth. Just two of the wealthiest senatorial families in

57 C.E. controlled an estimated wealth, equivalent in US dollars, of 20 billion dollars. ${ }^{2}$

The ruling class was comprised of three subsets: the Senate, the Equestrian Order, and the Deurion Order. The lower class was divided into two basic subsets: the Free Poor and the Destitute. The buffer between the wealthy and the poor was the class known as "The Respectable Populace." Figure 1 illustrates class ranking in the Roman Empire.

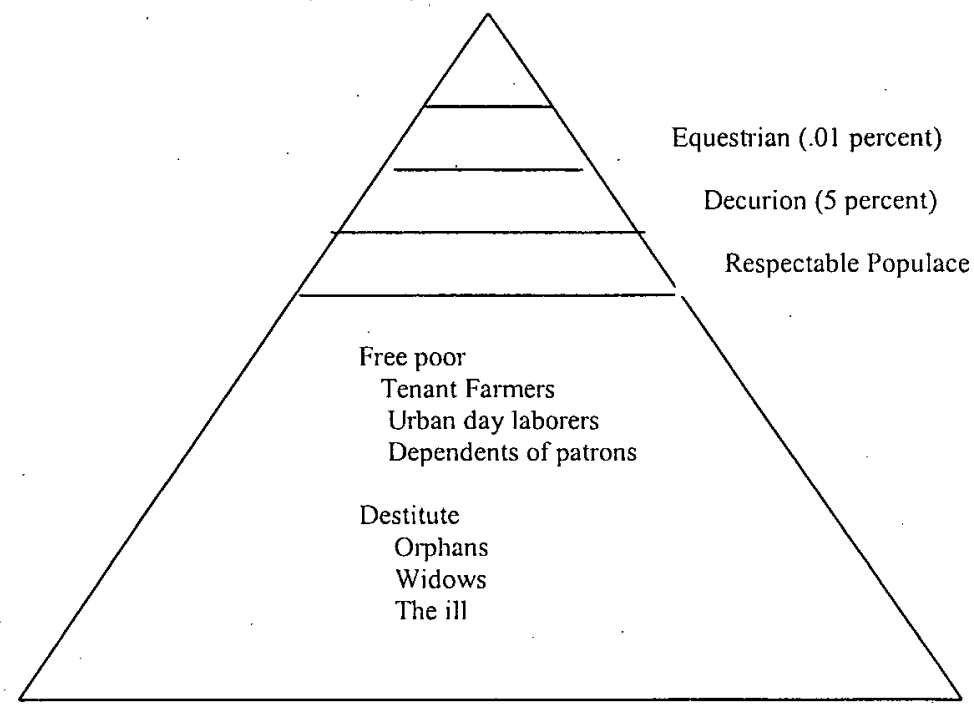

Fig 1. Class in the Greco-Roman World, from James S. Jeffries, The Greco-Roman World of the New Testament Era: Exploring the Background of Early Christianity (Downer's Grove, IL: InterVarsity Press, 1999).

\footnotetext{
' James S. Jeffries, The Greco Roman World of the New Testament Era: Exploring the Background of Early Christianity (Downers Grove, IL: InterVarsity Press, 1999), 180, 181.

${ }^{2}$ Ibid., 183 .
} 
The respectable populace would be roughly equivalent to today's middle class. Jeffries warns, however, that one should avoid the temptation to call this a middle class since such a modern term would be misleading. ${ }^{1} \quad$ Yet there are similarities of values and lifestyle that cannot be ignored. This group was composed of small land owners, craftsmen and shopkeepers. It also included the middle and lower ranks of Roman citizens in the army, from centurions to ordinary legionary soldiers and veterans. ${ }^{2}$

Like today's middle class, "their level of respectability in the eyes of the upper class was in direct proportion to the amount of work they did through the agency of others, rather than with their own hands. ${ }^{3}$ Like the middle class of today they grouped themselves by occupation and trade associations. : Like the middle class of today, in imitation of the aristocracy, they feasted as lavishly as they could. ${ }^{4}$ Their values were similar to the work ethic of today's middle class; they highly valued honesty in business dealings. ${ }^{5}$ And unlike the poor of their era and the middle class of our era, they enjoyed some degree of upward mobility.

Of particular interest is how this class of individuals is seen in the New Testament Church and how their presence may have impacted social relations. Jeffries asserts, "Probably most of the urban dwelling Christians named in the New Testament belonged to this group."

\footnotetext{
${ }^{1}$ Ibid., 188.

${ }^{2}$ Ibid.

${ }^{3}$ Ibid.

${ }^{4}$ Ibid.

${ }^{5}$ Ibid.

${ }^{6}$ Ibid.
} 
The social statuses of Christians place them for the most part in the middle and lower range of class and status. Overall, the typical Pauline Christians were free artisans, or merchants of with small income. Their congregations brought together people from several social levels. Most of these probably could do little more financially than to provide a living for their families. But others were wealthy enough to travel and act as patrons for Paul and young Christian communities. The extreme top and bottom of society are absent from the churches in the New Testament, however.

In Acts the reader is given some limited insight into the various classes and the subsequent class tensions that arose in the early Church. Michael Pocock writes:

The Book of Acts demonstrates how the people of God can and did reach out and incorporate those very different cultures into their fellowship. That's why the Book of Acts is a textbook for ministry in multi-cultural communities. .... Acts identifies the basis for success in multicultural ministry--the Holy Spirit. . . Acts demonstrates how to resolve tensions in a multi-cultural church. ${ }^{2}$

As new Christians joined the church, a new community emerged that was not based upon the static, rigid rule of Roman social order but a new Christian ethic that did not esteem one above the other. We see this new ethic played out in a tangible way as they "sold their possessions and goods, and parted them to all men, as every man had need" (Acts 2:45). In Acts 4:32, 34 we read, "The multitude of those who believed were of one heart and soul: and not one said that any of the things which he possessed was his own; but had all things in common. For there was no needy person among them: for as many as were possessors of lands or houses sold them, and brought the price of the things that were sold and laid it at the Apostles' feet: and distribution was made each according to his need" (Acts 4:32, 43).

\footnotetext{
${ }^{1}$ Ibid, 194.

${ }^{2}$ Michael Pocock, "Compass for the Journey," in Cultural Change and Your Church: Helping Your Church Thrive in a Diverse Society, ed. Michael Pocock and Joseph Henriques (Grand Rapids, MI: Baker Books, 2002), 92.
} 
From this verse we may conclude several points. First, there were at least two classes present in the Church: the poor, which included the destitute widows and orphans (Acts 6), and those who possessed property and other possessions. Thus, there was undoubtedly a small class of free poor and even members of the respectable populace who acted as patrons for the burgeoning movement. Second, we may conclude that this willingness to eradicate class lines was not the result of simple human philanthropy. Rather the Bible makes it plain, "And with great power the Apostles gave witness of the resurrection of the Lord Jesus: and great grace was upon them all" (Acts 4:33). It was the preaching of the Christ who died for all and rose for all that provided the impetus for their radical renunciation of the prevailing class/status system of the day. And, it was the grace of God that supernaturally empowered them to defy the prevailing social order and transcend tradition.

But the Book does not hide the fact that this new community was not a utopia. Still infected by the contagion of sin, outbreaks of selfishness and prejudice were evident. The story of Ananias and Sapphira provides an example of selfishness and greed that ran contrary to this new spiritual ethic.

In Acts 6, the rift in the community as a result of class and ethnic tensions is evident. Luke records, "And in those days, when the number of the disciples was multiplied, there arose a murmuring of the Grecians against the Hebrews, because their widows were neglected in the daily ministration" (Acts 6:1). The Hellenists were Greekspeaking Jews who had been born abroad and had taken up residence in Jerusalem. They often had their own synagogues, and from this group Christians had won many converts. ${ }^{1}$

\footnotetext{
${ }^{1}$ Ernst Haechen, The Acts of the Apostles: A Commentary (Oxford, England: Basil Blackwell, 1971), 260, 261.
} 
A daily distribution was made out of common funds, provided by the voluntary pooling of resources. ${ }^{1}$ In the Jewish system of relief, every Friday the local poor would be given enough money for fourteen meals; the destitute and transients would receive daily offerings of food from the tray. But the Christians, no longer supported by the Jewish relief system, seemed to have created a daily distribution. ${ }^{1}$ The system was designed to provide equally for the needs of all. But here in Acts 6, we find unequal distribution on the basis of culture and class.

Those being overlooked in the distribution were of the lowest class. They were women; they were widows; and they were Greek. While being Greek may have added status outside of Jerusalem, it had none inside the sacred city. Whether the slight to these women was intentional, we cannot say with certainty. What can be said is that the Hellenists perceived the slight to be intentional. The fact that Luke records this incident, with great specificity, seems to indicate that there was legitimacy to their claim. It appears as though the new community had fallen away from its original ideal of having all things in common.

It appears that culture determined status. The Hebrew Christian women were of the same faith and the same economic class as the Hellenist women. At this early stage in the development of the Church, there is no record of the conversion of large numbers of Gentiles, although there were obviously some in that Acts 6 mentions Nicolaus, a proselyte from Antioch. It can be assumed that both the Hebrews and the Hellenists were, for the most part, Jews. However, the Hellenists were being discriminated against

\footnotetext{
' F.F. Bruce, Acts of the Apostles: The Greek Text with Introductory Commentary (Grand Rapids, MI: Wm. B. Eerdmans Publishing Company, 1965), 151.
} 
because of their culture and even ethnicity. They were Jews of the Diaspora. Perhaps some had mixed lineages. They spoke a different language; their customs were foreign; and because they had worshiped in separate synagogues, their style of worship may have been different. Thus, the Hellenists of the same class were assigned a different status from their Hebrew counterpart.

It is possible for the majority culture to view the Black middle class with hostility or indifference, in the same fashion as the Hebrews viewed the Hellenists. Like the early Christians, both Blacks and Whites share the same faith, share the same class, but there may be significant cultural divides concerning experience, modes and means of expression, and styles of worship. Discrimination poses a significant enough threat to the unity of the community and warrants examination and intervention, whether intentional, unintentional, or merely perceived as intentional.

How did the early Church respond to this rift in the community? The twelve apostles gathered all the disciples together and said, "It is not right for us to neglect the ministry of the Word of God in order to wait on tables" (Acts 6:2). First, leadership listened. The apostles did not assume that the charges were true or untrue. Instead they listened to argument and the feelings of the most vulnerable group, the Hellenists. Second, they acted immediately to preserve the unity of the body. The apostles did not pretend as though culture or ethnicity made no difference. They accepted the reality of culture, and understood that cultural, ethnic, and class tension within the body is counterChrist and begs a response. Acts 6:3 continues, "Brothers choose seven men from among you who are known to be full of the Spirit and wisdom. We will turn this responsibility over to them." Third, they made a culturally sensitive intervention for the minority group

\footnotetext{
${ }^{1}$ Haechen, 262.
} 
that included their full participation and consent. The context suggests, and most scholars agree, that all of the deacons chosen were Hellenists, in that all their names were Greek. Fourth, the apostles made a structural realignment to address the challenge: the appointment of officers and the creation of a new office of deacon.

The decisions and actions of the apostles in this instance were informative to the community and formative for the community in three ways. First, it informed the community that culture, ethnicity and class must never be allowed to destroy Christian fellowship. Second, it informed the community on a process that may be used to resolve differences that destroy fellowship. Third, the decision was formative. Raymond Brown expounds,

The acceptance of the suggestion made by the Twelve was a decision in the early church for pluralism and for what we have come to call today 'the hierarchy of doctrine'. The cultural and theological disagreements that existed in Jerusalem between the Hebrews and the Hellenists were implicitly judged as less important than their common belief in Jesus. ${ }^{1}$

Acts traces the development of the early Christian Church as its mission expands beyond the borders of Jerusalem, Judea, and Samaria and moves to the utter ends of the earth. It describes the theological, missiological, and the sociological challenges in an ecclesiastical context and from a Christological perspective. The Church in Acts exists because of the risen Christ; it is empowered by the Spirit of Christ. And so, its modus vivendi and its modus operandi must arise out of the method of Christ. That is why Acts 6 is pivotal in the Book. The challenge of how to convey a universal message, born in Palestine, without it being contaminated by, constrained by, or confined by the place of its earthly birth, would prove challenging.

\footnotetext{
' Raymond E. Brown, An Introduction to the New Testament (New York: Doubleday, 1997), 294.
} 
Later, Peter would face the challenge with Cornelius. The Jerusalem Church would grapple with the challenge at the Jerusalem Council. Fierce debates and disagreements would plague the Church over the acceptance of Gentiles and the requirements of membership for Gentiles. Paul would face numerous challenges among the Gentiles who were steeped in the class system of the Empire. And yet, the Church did make it through the rough waters of economic disparities, ethnic division, and class diversities. But its first test is Acts 6 . Would the new way of Christ community surmount the way of culture and class? Would the way of the Christ community survive against the prevailing prejudices of the day? The answer to both questions is, "Yes." How then does this pericope inform the present study? The Church in Acts was in transition from being a Jewish sect into a new universal movement. The Church was in transition from being a homogenous Palestinian movement into a heterogeneous, multi-cultural one. The Acts account demonstrates that cultural, ethnic, and class tensions may arise in churches in transition. This account also shows that ignoring the issues or invalidating a person's perceived experience will not resolve the internal threats to Christian fellowship. Abandonment of the ideal of and the responsibility to Christian fellowship is not an option.

The Greeks were not asked to leave. Neither can the Church, exclude the Black middle class from the fellowship because of the inevitable challenge of ministering to them. Leadership must be astute to recognize the threat to unity and the act with dispatch to ameliorate the threat to unity. And, the intervention in the case of ethnic and cultural challenges must be culturally sensitive and appropriate. Finally, the Acts account confirms that the Church survived this crisis in transition. 


\section{Class in the Epistle of James}

The Epistle of James is one of the most controversial writings in the New Testament. Questions have arisen over the authenticity of its authorship. ${ }^{1}$ Some claim the work is a later edition to the canon, written by a pseudonym perhaps in the third or fourth century. Others claim the work to be authentic written by James early in the first century, but debate exists as to which James wrote the epistle.

But apart from debates over the authorship of the epistle, there have been many debates over the content of the letter. Luther despised the letter and thought it unworthy for sacred canon. He claimed that unlike the writings of Paul where the gospel is seen so explicitly, this letter barely mentions Christ. ${ }^{2}$ Luther's chief complaint was, “This epistle of James only drives you to the law and its works. . . He calls the law a law of freedom although St. Paul calls it a law of slavery, wrath, death, and sin."3 James speaks eloquently of the relationship between faith and works, placing a pragmatic moral and

1 There has been some debate over the authorship of the epistle. There are at least five possibilities for its authorship. The author known as James could be: (1) The father of Judas, not Iscariot, one of the Twelve (Luke 16:6); (2) The son of Alphaeus a member of the Twelve (Matt. 10:3; Mark 3:18; Luke 6:16); (3) James the Younger mentioned in Mark 15:40. Not much is known of him; (4) James, the brother of John, the son of Zebedee (Matt 10:2; Mark 3:17; Acts 1:13); (5) James, who is called the brother of Jesus (Mark 6:3; Matt 13:55).

Of the varying possibilities, it appears that only two are reasonable assuming that the epistle is not written under a pseudonym: either the author is the son of Alphaeus, or the brother of Jesus. The SDA Commentary postulates that the author is the son of Alphaeus, on of the Twelve. See "James," The Seventh-day Adventist Bible Commentary, ed. Francis D. Nichol (Washington, DC: Review and Herald, 1953-1957), 7:500). Although several theories challenge this assumption including the Hieronymian Theory of Jerome which postulates James to be the cousin of Jesus, The Epiphanian Theory holding James to be the half-brother of Jesus, and the Helvidian Theory summing James to be the uterine brother of Christ. Most alternatives to the son of Alpheus Theory conclude James to be the brother of Jesus. (Barclay, 15-20). But almost all commentators would agree with the statement in the SDA commentary, "In conclusion, it may be said that the authorship of James remains as unsettled question" (7: 500).

${ }^{2}$ William Barclay, The Letters of James and Peter, rev. ed. (Philadelphia: The Westminster Press, 1976), 6 .

\footnotetext{
${ }^{3}$ Ibid., 7.
} 
ethical claim upon faith. Quite emphatically he asserts, "Faith without works is dead" and "show me your faith without your works and I will show you my faith by my works" (Jas 2:18).

It is true that James does not appear to be the systematic theologian of Paul, yet upon examination of the work one can see the ecclesiological import of this work. James writes as a pastor giving council to the flock. The epistle is written in refined Greek, is a literary work written in alliteration, assonance, and wordplays that are woven into the letter like a thread in a tapestry. The epistle in this sense appears to be in the form of a classical homily written in the style of the Greeks with the ethical standards of the Jews. Writes R. V. G. Tasker the ethical implications of this new faith are translated into practical realities in the epistle. ${ }^{1}$

To understand James, one must understand that his principle concern seems to be practical everyday godliness as lived out in the community of believers. James sees the inconsistency of human behavior, which he calls 'double-mindedness,' as the chief cause of strife, partiality and disunity in the church. This double-mindedness had also created class tensions within the church. James, more so than any other New Testament writer, attacks classism based upon wealth. He confronts prejudice and calls the church back to the ethical claims of the law. Thus James' challenges the status quo. It is James' frank discussion of wealth, poverty and class that has also made the epistle controversial.

James begins his treatise on wealth and poverty in chap. 1 where he makes a startling statement:

' R. V. G. Tasker, The General Epistle of James and Peter: An Introduction and Commentary, Tyndale New Testament Commentary Series (Grand Rapids, MI: Wm. B. Eerdmans Publishing Company, 1990), 11. 
Let the believer who is lowly boast in being raised up, and the rich in being brought low, because the rich will disappear like the flower in the field. For the sun rises with its scorching heat and withers the field and its flower falls' and its beauty perishes. It is the same way with the rich man (Jas 1:9-11 NRSV).

Here James places a vivid contrast between the two classes. It is obvious from the context that the author is speaking of wealth and poverty in the material sense. But he also draws spiritual conclusions from the material circumstances of the two distinct classes. The humble poor are exalted and the rich are humiliated. Writes Barclay, "As James saw it, Christianity brings to every man what he needs. Mayor remarks, "As the despised poor learn self-respect, so the proud rich learn self-abasement. . . Christianity brings to the poor man a new sense of his own value. . He learns that he matters to God." James also attacks the deceitfulness of riches as a means of security. Likening the status of wealth to that of a wilting flower under the blaze of the sun, James says, "its beauty perishes." The comparison of what is short-lived in human life with the flower of the grass is common in the Bible. ${ }^{2}$ James appears to draw from the imagery of Isaiah and applies the withering flower imagery to the rich. ${ }^{3}$ He appeals to the rich in this passage to look for things of eternal value. "So then, James urges the rich to cease to put their trust in that which their own power can amass. He urges them to admit to their essential human weakness and humbly to put their trust in God, who alone can give the things which abide forever." 4

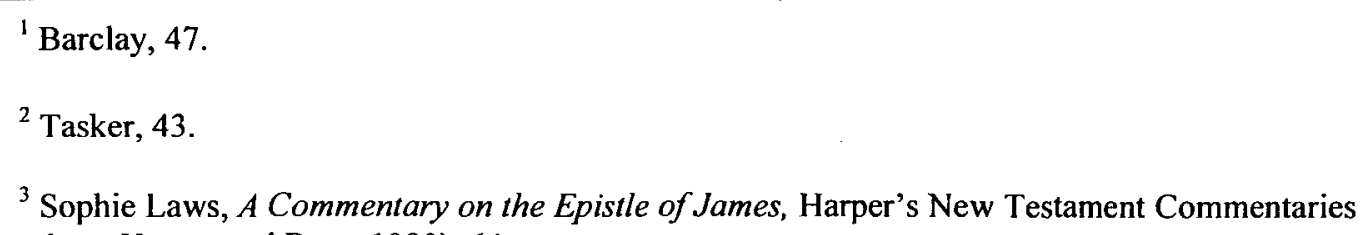
(San Francisco: Harper and Row, 1980), 64.

${ }^{4}$ Barclay, 48. 
Jas. 1, asserts that the status of both rich and poor have been transformed because of this new relationship with Christ. Tasker comments that this new level of status given to the two classes challenges their double-mindedness: "This double-mindedness is essentially the mark of the man who is trying to serve both God and mammon. The Christian brother, therefore, is here bidden to find joy, not in the satisfaction of worldly ambition, but in the new status into which he has been brought in Christ."1

After James has laid the foundation of his argument of this new status in Christ, he addresses the attitudes of both classes that are creating tension in the church. James does not speak against the wealthy and sentimentalize the poor. James is concerned with disunity and factionalism in the church, and so speaks to that issue regardless of whom he might offend. By examining the epistle through the eyes of Pastor James, who sought to bring unity to the church divided by class, the inherent unity of the letter becomes obvious. He deals with two class-specific sins: the sin of lust and the $\sin$ of partiality.

\section{The Sin of Lust}

Verses 13-15 may be seen as a continuation of James's discussion on wealth and poverty, because James next goes on to warn the reader against temptation and lust. Lust, $\varepsilon \pi \imath \theta v \mu \alpha$, is to desire or to desire over. ${ }^{2}$ This would seem to be quite strange for the author to introduce a new disjointed concept in chapter one after having made such a poignant statement on the new status of the brothers in Christ. And so it is important to read what James says on temptation and lust juxtaposed to what he has just said on

\footnotetext{
${ }^{1}$ Tasker, 42.

${ }^{2}$ Harold K. Moulton, The Analyitcal Greek Lexicon Revised, (Grand Rapids, MI: Zondervan, 1978). s.v. " $\varepsilon \pi \imath \theta u \mu l \alpha . "$
} 
wealth and poverty. He has just urged the rich not to trust in his riches. Now he says to the rich who may be forced to relinquish their wealth and earthly status to accept this new status, "Blessed is anyone who endures temptation. Such a one has stood the test and will receive a crown of life" (Jas 1:12 RSV). Notice here James points the reader back to the eternal reward, the enduring wealth that comes as a result of passing through the temporary, transitory test of this world. It is a word of comfort to the wealthy who now finds himself in a position of humiliation. It is also a word of comfort to the humble poor who must endure the test of poverty. The poor have the assurance that their exaltation will come, and that in the end they shall receive their eternal reward.

James not only points each class to their eternal reward, but he also gives a stern warning against lusts, the desire for the temporary earthly reward. This is of a particular challenge to the poor, who lacking the finer things of this world, tend to lust after them. The poor are prone to lust for what they do not have; it is lust born of covetousness. Part of the tension and strife in the church had to do with the jealousy and envy of the poor of the wealthy. Notice the literary comparison between wealth and lust, shown in table 18 .

TABLE 18

\section{LITERARY COMPARISON IN THE EPISTLE OF JAMES: WEALTH AND LUST VERSUS CHRIST}

\begin{tabular}{|l|l|l|}
\hline Wealth & Lust & Christ \\
\hline $\begin{array}{l}\text { Wealth is temporary and } \\
\text { brings temporary status. } \\
\text { Jas } 1: 10\end{array}$ & $\begin{array}{l}\text { Lust brings temporary reward. } \\
\text { It is conceived and gives birth. } \\
\text { Jas } 1: 14\end{array}$ & $\begin{array}{l}\text { Eternal status in Christ is born } \\
\text { by the word of truth. } \\
\text { Jas } 1: 18\end{array}$ \\
\hline $\begin{array}{l}\text { Wealth brings death. } \\
\text { Jas } 1: 11\end{array}$ & $\begin{array}{l}\text { Lust brings inevitable death. } \\
\text { Jas } 1: 15\end{array}$ & $\begin{array}{l}\text { Status in Christ brings a crown } \\
\text { of life. } \\
\text { Jas } 1: 12\end{array}$ \\
\hline
\end{tabular}


James goes on to remind his readers, whether poor or rich, "Every good and perfect gift is from above and cometh down from the Father of Lights in whom there is no variableness, neither shadow of turning" (Jas 1:17). The temporary reward of the earthly can never satisfy the desire, $\varepsilon \pi \imath \theta v \mu \imath \alpha$, but the gift that is from above is perfect, $\tau \varepsilon \lambda_{\imath o v}$. The word translated "perfect" in this passage means complete. ${ }^{1}$ The gift of God makes one complete, therefore satisfied. This word is used four times in the epistle to speak of the Christian being made complete through endurance (Jas 1:4). It is used to describe the law of God in Jas 1:25. And it is used to describe the mature Christian who is able to bridle his tongue in Jas 3:2.

To James, true wealth is a gift from God. It is a character forged in trials and testing, a character evidenced in endurance through the vicissitudes of this life, a character that is consistent with the perfect righteous claims of the law of God. But it is also a character that can only be obtained as a gift from God because of a new birth. "In fulfillment of his own purpose, God gave us birth by the word of truth, so that we would become a kind of first fruits of His creatures" (Jas 1:18 RSV). This character is the Christian's new status in Christ. This new status releases the Christian from the conventional social confines of a fallen world, and impels him to a new social order, not based upon human social convention.

If the $\sin$ of the poor is lust born of envy and covetousness, then the sin of the wealthy is lust born of selfishness. The tendency of the wealthy is to hoard their

\footnotetext{
${ }^{1}$ Moulton. s.v. "$\tau \varepsilon \lambda$ ıov."
} 
"Pure religion and undefiled before God and the father is this--to visit the fatherless and widows in their affliction, and to keep himself unspotted from the world" (Jas 1:27). Since they have now been born of the Word, James says to the wealthy, "Be doers of the word" (Jas 1:22). He rhetorically asks, "If a brother or sister be naked, and destitute of daily food, and one of you say unto them, 'be ye warmed and filled; notwithstanding you give them not those things which are needful to the body; what doth it profit?" (Jas 2:15, 16). The new status in Christ demands a response equal to the claim of faith, for James declares, "Even so faith, if it hath not works, is dead, being alone" (Jas 2:17).

Both classes--the rich and the poor--seem to have fallen prey to the sin of lust, whether lust born of covetousness or lust born of selfishness. In chap. 2 of the epistle, the author exposes both the prejudice of privilege enjoyed by the wealthy and the willing deference of the poor to the prejudices of the wealthy, as though wealth permits privilege in the church. "My brothers, as believers in our glorious Lord Jesus Christ, don't show favoritism" (Jas 2:1 NIV). Discrimination on the basis of class is contrary to the claims of the gospel. He illustrates:

If there should come a man into your meeting a gold-ringed gentleman wearing splendid clothes, and there should also come in a poor man in filthy clothes, and you should look at the man wearing splendid clothes and say, 'You sit here. In a good place, and say to the poor man, 'You stand there, or sit here under my foot stool. Would you have not made distinctions in your own minds and have become judges who make corrupt decisions? (Jas 2:1-4)

That James is referring to two classes can hardly be refuted. The church was showing deference to the wealthy and ill will to the poor. The poor man ( $\pi \tau \circ \chi \circ \sigma$, or 
beggar as opposed to $\pi \varepsilon v \varepsilon \sigma$ a working poor) is wearing vile raiment or unwashed, poorly kept clothes. ${ }^{1}$ By contrast Sophie Laws describes the gold-ringed gentleman:

The gold ring was a part of the insignia of the equestrian order, the second rank of the Roman aristocracy. Equestrians were customarily wealthy, for there was a proper qualification for the rank, and this could be achieved through trade and commerce as would not have been thought inappropriate by the senatorial order . . . and it was still the road to careers in the civil service, perhaps to procuratorial office such as Felix and Pilate held in Judea. Such a person would provide a particularly striking example of the rich man; and would also be a covetable patron for a minority group. ${ }^{2}$

Over the years of pastoral ministry, I have witnessed such congregations. A wellto-do middle class church, which had a number of professionals and skilled craftsmen, began to be inundated with poor immigrants from Haiti and Hispanics from interAmerica, and class tension began to arise. At one particularly enlivened board meeting, the members desired to evict the Hispanic congregation that was sharing the facility because they were "dirty" and "poor," and they presented the "wrong image" for the church. I have also pastored congregations that were predominantly poor. When a new professional came to town, they fawned over this new member as though he were Christ himself, seeing this man not a soul for whom Christ died, but rather a deep pocket who could be used to get the church out of debt.

This deference to the wealthy by the wealthy is the partiality born of selfprotection and fear. The deference to the wealthy by the poor is the partiality born of manipulation. Both are two sides of the same coin that see persons of means as objects. Both seek to dictate the social order of the church, not based upon the claims of the risen

\footnotetext{
1 "James" Seventh-day Adventist Bible Commentary, 7:517.

${ }^{2}$ Laws, 98 .
} 
life, but the claims of the former pre-new-birth, fallen life. And because both are born of selfish lust for power and control, both are destined to create class conflict in the body.

These sins of lusts, the desire to control and manipulate the church, had boiled over into open class conflict. It appears as though the privileged position of the wealthy had sparked jealousy and envy among the poor. James describes this conflict in chap. 4 of the epistle:

What causes fights and quarrels among you? Don't they come from your desires that battle within you? You want something but don't get it. You kill and covet, but you cannot have what you want. You quarrel and fight. You do not have, because you do not ask God. When you ask, you do not receive, because you ask with wrong motives, that you may spend what you get on your pleasures. (Jas 4:1-3 NIV)

Now the King James Version uses the word "lusts" in vs. 1 and vs. 3, thus reading, "From whence come wars and fightings among you? Come they not hence from your lusts that war in your members?" (Jas 4:1). The word translated "lusts" in the KJV is the word $\eta \varepsilon \delta o v \alpha l$, meaning pleasures or evil desires. It is a word often associated with the wanton abandonment of discretion when in pursuit of sexual pleasure. Because of the use of this word, many may conclude that James is speaking specifically about sexual or other vices. However, an examination of the use of the word in the New Testament and in the context of James's argument demonstrates that he is once again talking about the desire for wealth.

Pleasure $(\eta \varepsilon \delta o v \alpha \imath)$ is used only three other times in the New Testament. In both Titus 3:3 and 2 Pet 2:13 it is used to describe the wanton abandon of discretion in passionate pursuit of self-gratification. However, Luke places the word in the lips of our Lord in Luke 8:14 in which Christ likens the seed that fell among the thorns as being "choked with cares, and riches, and pleasures ( $\eta \varepsilon \delta o v \alpha \iota)$ of this life." So, Christ links 
the use of this word with riches and that which may be obtained in this life. Upon examining James, there is little doubt that he also similarly uses the word. "You ask, and do not receive because you ask wrongly, in order to spend it on your pleasures ( $\eta \varepsilon \delta o v \alpha \imath)$ ". The jealous desire to obtain wealth, which he calls lusts $(\varepsilon \pi \iota \theta v \mu \iota \alpha)$ in chap. 1 , is so that the person may spend it on his lusts $(\eta \varepsilon \delta o v \alpha l)$ in chap. 4 . It is the same fallen desire in chap. 1 as in chap. 4--the desire to have the immediate, temporary, transitory reward of this life in this life, versus receiving the eternal reward through patient endurance. To seek the temporary pleasures ( $\eta \varepsilon \delta o v \alpha 1)$ is the wanton abandon of the passionate pursuit of the eternal. It is spiritual fornication. To this end, James calls them "adulterers and adulteresses" (Jas 4:4). "Know ye not," asks James, "that the friendship of the world is enmity with God?" (Jas 4:4).

James's counsel to the Church, caught in class conflict, is to seek the wisdom of heaven. "Who is wise and understanding among you? Show by your good life that your works are done with gentleness born of wisdom" (Jas 3:13). Notice how James picks up again the motif of birth. Those whom have been birthed "by the word of truth" "in fulfillment of his own purpose" are to manifest the gentleness of God born of wisdom. He proceeds with his argument in chap. 3 :

But if you have bitter envy [the sin of the poor] and selfish ambition [the sin of the wealthy] do not be boastful and false to the truth. Such wisdom does not come down from above, but is earthly, unspiritual, devilish. For where there is envy [the sin of the poor] and selfish ambition [the sin of the wealthy], there will also be disorder and wickedness of every kind. (Jas 3:14,15 NRSV)

To James, both classes are guilty before God by resorting to their fallen nature rather than living in the light of their new status. His recipe for peace in the church is found in 3:17 and18, "But the wisdom from above is first pure, then peaceable, gentle, 
willing to yield, full of mercy, and good fruits, without a trace of partiality [the sin of the rich] or hypocrisy [the sin of the poor]. And a harvest of righteousness is sown in peace for those who make peace."

But how can one's fallen nature and social upbringing be brought into harmony with the will of God and accept this new social order of oneness of community? James finds the same prescription as does Paul, by grace. James asserts, "God resists the proud, but gives grace to the humble" (Jas 4:6). By grace the man of humble circumstances is exalted and by grace the rich are made humble that God may exalt him. And the God who gives wisdom (1:5) and the God who gives every good and perfect gift (1:17) is the God who gives more grace (4:6). Those who are humble enough to receive the free gift are brought into relationship with God and into fellowship with their brothers and sisters. They are no longer separated by the artificial distinctions of class. They are no longer slaves to worldly ambition and envy. They are no longer masters and servants, but rather they are all equally endowed with the riches of the wisdom of heaven, cohabitating peaceably in one fellowship while awaiting the eternal reward of the crown of life.

\section{Summary}

So what lessons may be learned from James about class and classism that may inform our approach to ministry to the Black middle class? First, class tension can arise in an ethnically homogenous environment. James addresses the twelve tribes of Israel. Even though people share a common ethnic, cultural, and religious background, it does not necessarily prevent class tension from arising. Black middle class churches in transition should not assume that because all persons share ethnicity, they share the same values. Approaches must be class sensitive. Second, all socio-economic classes are fallen 
and each is susceptible to its own unique sin. The Black middle class must be challenged to see themselves as sharing the larger class of fallen humanity. Third, the person who is in Christ obtains a new status as a born-again individual and her allegiance is to Christ and not to one's class. Fourth, out of this new status arises a new social order in which persons who were estranged because of class are now brothers and sisters in Christ. Fifth, the healing of class tension is the by-product of the work of grace upon the humble and receptive heart.

\section{Ellen White's Statements on Class and Race}

In order to examine the ideas of Ellen White in relation to the subject of class, one must take into account a few considerations. The idea of class has been in existence in most known civilizations in the world. Most assuredly in biblical times, we see the delineation of class. But in the late nineteenth and early twentieth century the notion of a clearly defined middle class as we know it today had not come to full maturation. The United States was still primarily an agricultural society. But as the Industrial Revolution began to fully blossom, the factories that produced the goods spawned a new urban migration. A new managerial class and working class began to emerge.

So Ellen White does not particularly address the notion of middle class, because it was not as highly developed in her time as it is today. It certainly was not the economic engine of the consumer economy, or the political voting block as we presently know it. Highly developed in her time were class distinctions based or wealth and race. She was very much aware of the class distinctions within the church and the tendency of the Seventh-day Adventist believers to congregate around persons of their own class and 
race. From the statements of Ellen White, several importantly held beliefs may be extrapolated in regard to class. The comments of Ellen White suggest missiological and Christological implications of class for the Church.

The Adventist Church has been challenged to explore, examine, and respond to various classes. Ellen $\mathrm{G}$. White remarks:

It was never God's purpose that society should be divided into classes, that there should be an alienation between the rich and the poor, the high and the low, the learned ad the unlearned. But the practice of separating society into distinct classes is becoming more and more decided. ... God designed that those to whom $\mathrm{He}$ entrusted talents of means, ability and gifts of grace, should be good stewards of His beneficence, and not seek to reap all the advantages for themselves. ${ }^{1}$

First, we learn that class distinction was never a part of God's original social order for humanity. According to Ellen White, class distinction must therefore have arisen as a result of the fallen condition of the world. The study of the rise of class parallels the rise of $\sin$. Class is a human construct and not a divine construct and therefore should not be treated as such. Class may be considered a human adaptation to sin or a human accommodation because of sin. Class is part of the sociology of sin; according to White, "Jesus began the work of reformation by coming into close sympathy with humanity.... He was seeking to break down barriers which separated the different classes of society that He might bring men together as children into one family." 2

Second; the removal of class distinctions was part of the ministry of Christ on earth. Notice, Ellen White does not say that removal of class distinction was central to the ministry of Christ. The rearranging of the social order on this fallen planet could never be

${ }^{1}$ Ellen G. White, The Southern Work (Washington, DC: Review and Herald Publishing Association, 1966), 37.

${ }^{2}$ Ellen G. White, Desire of Ages (Mountain View, CA: Pacific Press, 1940), 150. 
accomplished as long as the root cause of that perverted social order, sin, remained. But Christ, who did not sin, could not and would not be bound to or bound by a fallen human construct. Christ, by His action, demonstrated that it is the ultimate aim of God to reconcile His disaffected children into one family. Class is an "artificial barrier," a sin condition, from which humanity needs redemption. The work of reconciliation does not have to wait for the eschaton. Christ introduced the redeemed community ethic and social order while here on earth.

Third, Christians are expected to extend themselves and expend themselves in order to reach all classes of people. As wise stewards, they are to use their gifts to reach those of differing classes. In summation, the prophet is simply stating that class exists and that the church of God is duty-bound to both recognize it and to respond to issues of class for the sake of expanding the kingdom of God. White states, "The gospel invitation is given to the rich and the poor, the high and the low and we must devise means for carrying the truth into new places and to all classes of people. ${ }^{1}$

Fourth, we learn that the gospel commission carries an imperative to extend the invitation to all classes of people. Because Christ was not bound by class distinctions, neither should His disciples be bound. White says:

Among the Jews the question, 'Who is my neighbor?' caused endless dispute. . . . This question Christ answered in the parable of the good Samaritan. He showed that our neighbor does not mean merely one of the church or faith to which we belong. It has no reference to race, color, or class distinction. Our neighbor is every person who needs our help. Our neighbor is every soul who is wounded and bruised by the adversary. Our neighbor is everyone who is the property of God. ${ }^{2}$

1 Ellen G. White, Medical Ministry (Mountain View, CA: Pacific Press, 1932), 312.

${ }^{2}$ Ellen G. White, Christ's Object Lessons (Battle Creek, MI: Review and Herald Publishing Company, 1900), 377. 
Let national and denominational distinctions be laid aside. Caste and rank are not recognized by God and should not be by His followers. ${ }^{1}$

Given the above statements by White, one is forced to question whether it is wrong to even consider class in the dissemination of the gospel. Is it contrary to the method of Christ? Should we ignore all cultural differences, class distinctions? A brief examination of the following passage provides further clues as to White's thoughts on the subject:

No distinction on account of nationality, race, or caste, is recognized by God. He is the Maker of all mankind. All men are of one family by creation, and all are one through redemption. Christ came to demolish every wall of partition, to throw open every compartment of the temple, that every soul may free have access to God. ${ }^{2}$

Jesus taught His followers that they were debtors both to the Jews and to the Greeks, to the wise and the unwise, and gave them to understand that race distinction, caste, and lines of distinction made by man were not approved of Heaven and were to have no influence in disseminating the gospel. The disciples of Christ were not to make distinctions between their neighbors and their enemies, but to regard every man as a neighbor who needed help, and they were to look upon the world as their field given to every man his work, taking him from his narrow circle which his selfishness had prescribed, annihilating territorial lines and all artificial distinctions of society. He marks off no limited boundary for missionary zeal, but bids His followers extend their labors to the uttermost parts of the earth. ${ }^{3}$

In this statement, White uses the word "distinction" four times. What does she mean by the word "distinction" in this context? Her second sentence in this paragraph provides for us the answer. She states, "The disciples of Christ were not to make distinctions between their neighbors and their enemies, but to regard everyman as a neighbor who needed help, and to look upon the world as their field given to every man to work, taking him from his narrow circle which his selfishness had prescribed,

\footnotetext{
'White, The Southern Work, 21.

${ }^{2}$ White, Christ's Object Lessons, 386.

${ }^{3}$ Ellen G. White, In Heavenly Place (Washington, DC: Review and Herald, 1967) 319.
} 
annihilating territorial lines and all artificial distinctions of society." What White addresses by her use of the word "distinction" in this statement is the prejudice that prevents individuals from moving beyond their "narrow circle which (his) selfishness had prescribed." The narrow circle kept the Jews from the Greeks, the wise from the unwise, the neighbors (those who are like me) from the enemies (those who are not like me). Missionary zeal is hampered when the human construct of class distinction or racial prejudices prohibits the Christ mandate to extend the gospel "to the uttermost parts of the earth." Human prejudice should have "no influence" in "disseminating the gospel." It should not be a factor in deciding whether we should go, or to whom we should go. It cannot be used as an excuse for not going, or as a justification to go to some and not to others.

But it must be stated explicitly what Ellen White addresses here and what she does not address. In this statement, Ellen White is speaking primarily to the issue of mission and not primarily of methodology. Her point is that the disciples of Christ should work with all classes and races and not how we should work with different classes. The only 'how' she addresses is that the work should be done without prejudice. She is not addressing methodology but mission. The mission is clear and unambiguous.

\section{Summary}

How does this inform this study? If the Church were to follow the counsel of Ellen White, then White churches in transition would work toward the redemption of their "neighbor" without prejudice of race, color or class. The church cannot ignore the fact that ethnicity, color, or classes exist within the society or church, but it will not use those classifications to determine whether it chooses to minister to the Black middle 
class. Both the Black and White middle class churches in transition would understand that the means that are entrusted to them are to be used to benefit the work among all classes. They could not isolate themselves into middle class enclaves utilizing their resources to minister only to themselves.

\section{Oneness: A Biblical Mandate}

The words of Christ must be considered the ultimate authoritative reference for the Christian community. Christ's words define mission and praxis. Thus in attempting to construct ministry approaches to the Black middle class in churches in transition, then the Christ imperative found in John 17 must be considered. John 17 affirms the recognition of particularities, without the sacrifice of Christian unity.

The most significant statement on the subject of Christian unity (oneness) came directly from the lips of the Savior. In John 17:21, Christ says, "that they all may be one, thou Father art in me and I in thee, that they may be one in us: that the world may believe that thou hast sent me." This statement of Christ is brief and yet comprehensive for it asserts:

1. Oneness as a goal - "that they may be one"

2. Oneness as a divine principle - "as thou, Father art in Me and I in Thee"

3. Oneness with humanity is not only the desire of God, but is made possible in relationship with God - "that they may be one in Us"

4. Oneness as evidence to the world that Christ is indeed both the Reconciler and the very embodiment of the divine principle of unity - "that the world may believe that Thou hast sent Me." 
But what does it mean to be one? Depending upon the theological lenses through which one looks, one may arrive at very different conclusions. Does oneness mean sameness? Does oneness imply that the Church must work toward integration, assimilation? Does oneness simply mean the tearing down of the middle wall of partition (desegregation)? There are contextual clues within John 17 that give insight into Jesus' definition of oneness. His words must be considered determinative.

First, Jesus says in John 17:1, "Father the hour is come; glorify thy Son, that the Son also may glorify thee?" Here, oneness with the Father is expressed in terms of mutuality and reciprocity. The Son glorifies the Father, and the Father glorifies the Son. Since there can be no true reciprocity with equality, this reciprocity confirms the equality of the Father and the Son. So unity may be expressed as reciprocity based upon equality.

Second, we see another important aspect of unity emerge in vs. 5: "And now, O Father, glorify thou me with thine own self which I had with thee before the world was." Here Christ asserts His pre-existence. He states that He existed with the Father before the world was. In vs. $1, \mathrm{He}$ asserts His equality based upon the equality of reciprocity. But here in vs. 5, He asserts His equality with the Father based upon His (the Son's) sovereignty. He, the Son, existed with the Father before the creation of the world. He is Co-Creator and Co-Regent with the Father. There is a shared responsibility between the Father and the Son. So then, unity is not only reciprocity, it may also be expressed as shared responsibility.

Third, if responsibility is shared, then it must be shared around a common mission, a common purpose. This is reiterated in John 17:2. "And this is life eternal, that they might know thee, the only true God, and Jesus Christ whom Thou hast sent." The 
Father and the Son are committed to the fulfillment of a common mission, a common purpose--the redemption of humanity. So, unity is manifested is commonness of purpose.

But also, unity of purpose does not necessarily mean sameness of operation. While sharing responsibility and purpose, each Person has a specific role to play. The Father sends; the Son is sent (John 17:3). Knowing the Father is eternal life (John 17:3). However, the Son is the medium through which that life is imparted (John 17:2). The Father is glorified in the Son (John 17:4), and the Son glorifies the disciples (John 17:10). There is unity of purpose, but clearly different functions. So unity can be diverse in its operation.

Jesus' definition of unity or oneness offers useful principles to guide ministry. First, if unity is reciprocity based upon equality, then in order for persons to work in oneness, they must first recognize the true equality of the other. There can be no dominant and subservient. There can be no hint of superiority based upon race or class. Second, if unity is manifested in shared responsibility, then there can be no positional, patriarchal, or patronizing dominance in the church. Partners share responsibility and accountability. Third, if unity expresses itself in commonness of purpose and mission, then there cannot be a White church with a different mission from a Black church or a middle class church with a different mission from a poor church. The mission of all must be the mission of God and Christ, the redemption of all humanity. God was in Christ reconciling the world (the entire world) unto Himself. Finally, unity does not mean uniformity, but unity in diversity. 


\section{Relationships Between Philology and Theology:}

Linguistic Distortion of the Biblical Mandate

Philology was a discipline developed in the European Church in the nineteenth century because a theological question emerged: What language did they speak in Eden? So concerned were these scholars with the racial, ethnic, and cultural identity of our first parents that they sought to canonize their White supremacist views. ${ }^{1}$ In this instance, the Word of God was deconstructed into the words of men. The anthropocentric focus upon the language of humanity created what Vincent Bacote calls a "ghettoized theology," specific to a race or cultural group without sufficient "theological reflection to be universal in its ecclesiological effects."

While the study of philology as a theological discipline is no longer in vogue, there is a new linguistic discourse which seeks to make meaning of race in our ecclesiology. And as in the former discipline, the new philology imposes secular and anthropocentric notions upon the Word of God erecting a ghettoized theology. Theology is a human reflection in human words around the Word of God, and so one must be careful not to impose a dissonant vocabulary in our theological discourse on racial and class reconciliation. The language of discourse is socio-culturally mediated reflecting the attitudes and values out of which it emerges. Words carry with them not only meanings but also meta-meanings, connotations with denotations, implications that evoke images, implications with ramifications. Therefore, even when looking at the Word, that the

\footnotetext{
' Eugene Rivers, "The Responsibility of Evangelical Intellectuals in an Age of White Supremacy," in The Gospel in Black and White, ed. Dennis L. Okholm (Downer's Grove, IL: InterVarsity Press, 1997), 22.

${ }^{2}$ Vincent Bacote, "Theological Method in Black and Whites: Does Race Matter at All," in The Gospel in Black and White, ed. Dennis L. Okholm (Downer's Grove: IL: InterVarsity Press, 1997), 54.
} 
words mean the same thing to different hearers. Hiebert writes:

An example of variance in meanings assigned to the same form is found in the Christmas story. In Palestine shepherds were respected as devout men. In India shepherds are the village drunkards, and in Christmas pageants in more than one instance they came onto stage reeling drunk. In this case the form has been kept, but some of the meaning lost. The same loss can occur whenever we translate cultural forms such as campfire services, Christmas trees and altar calls.

More recently, translators have been concerned with 'dynamic equivalent' translations, in which the meaning is perceived, even if a different form is used. The result is translations that are better understood by the people. But the task is not as simple as it seems. We simply cannot translate word for word, using the equivalent meanings, for words, themselves, are products of a culture and reflect the basic values and assumptions of that culture. The fact is, there are no words in one culture that carry exactly the same meanings as the words in another culture. ${ }^{1}$

In current theological discussion on oneness, unity, and racial reconciliation in the Adventist Church several terms have been used. In the statement of "Recommendation From the Delegates" to the Summit on Race Relations, held in October 1999, the following resolution was passed:

Whereas the powerful presentations demonstrated the necessity of broad strategic plan of desegregation and harmony based upon our Lord's Prayer for "oneness" in His body. ${ }^{2}$

Notice, the term "desegregation" is equated with the term "oneness." But desegregation is not a biblical term. It is a term of social and political construction to describe a social and political process. It is a loaded term and it could have widely diverse connotations depending upon one's socio-cultural background. To a White North American who remembers the 1960s and the 1970s, the term desegregation can conjure up images of busloads of Black children invading a quiet suburban enclave. To a Black

\footnotetext{
'Paul Hiebert, "Culture and Cross-Cultural Differences," in Perspectives on the World Christian Movement: A Reader, ed. Ralph D. Winter and Steven C. Hawthorn (Pasadena, CA: William Carey Library, 1981), 374, 375. 1999.

2 "Recommendation from the Delegates," Adventist Review: North American Edition, December,
} 
person, the term may evoke fears of leaving the familiar to embark upon a journey into a hostile environment. To a White person, the term "desegregation" may further validate his notion that Blacks have intentionally segregated themselves and that there are no real barriers to integration. To Blacks, the term may suggest a dismantling of institutions that they consider important to the furtherance of work among Blacks. To link the term "desegregation" with the biblical concept of oneness is to infect the theological discourse with socio-cultural biases and run the inevitable risk of a ghettoized theology.

Theological discourse is not a neutral enterprise, because the words used are symbolic representations of persons, objects, or ideas. So the use of terms like integration, segregation, special interest, minority populations, and majority populations may first infect and then inflame the discourse. Osbourne, an attendee at the "Summit on Race," unwittingly made this point in his description of the dialogue at the summit:

My group included a lengthy discussion by Black lay and church leaders who had experienced racism in the appointment of church leaders and funding, issues that had led in part to separate conferences. One African-American maintained that having separate conferences was a "non-negotiable." A White leader who attends a multi ethnic church wondered if a better way might exist. Some Black leaders suggested that integration never worked and that we should focus on desegregation instead. I sensed that the issue would continue to generate discussion and division that could override much of the dialogue.'

The author states his concern that the issue being discussed would override the dialogue; what he did not grasp is that the issue is the reason for the dialogue. From his vantage point, the very concern of the Black members of his group was a non-concern. But what he describes is correct. True dialogue was being hampered because of the words used. What he describes is not simply a clash of words, but a clash of culture and

\footnotetext{
${ }^{1}$ Richard Osborne, "Floppy Disk Event or Revolutionary Summit?" Adventist Review, December 2, 1999, 10-11.
} 
experience expressed in culturally bound words. The clash of words is indicative of the clash of ideas rooted in the diverse historio-cultural experiences.

Culture is closely bound up with language, and is expressed in proverbs, myths, folk tales and various art forms, which become a part of the mental furniture of all members of the group. It governs action undertaken in the community, acts of worship or general welfare laws and administration of laws....

Culture is also the ideas people have of their world. Through their experience of it, people form mental pictures or maps of this world... This is not only a map of their world, but also a map for determining action. It provides them with a guide for decisions and behavior. ${ }^{1}$

The theological discourse on race and class must be purged of its secular terminology laden with secular connotations. Only as the Church returns to a biblical understanding of oneness will it be able to live out oneness as a reality, rather than romanticize it as an ideal. But to provide such a corrective, we must be clear about what oneness is and what it is not.

Oneness is not integration or the simple mixing together of ethnicities and classes without a common purpose. Oneness is commonness of purpose. Oneness is not desegregation or the simple removal of barriers that allow for interaction. Oneness is not a denial of cultural differences. Oneness recognizes culture as a medium to which the gospel speaks and through which the gospel speaks. Oneness is not cultural homogeneity, multi-cultural heterogeneity, or acculturation into a baptized ghettoized human culture.

\section{Oneness: Transcending Culture}

Oneness is not a denial of culture. But, should Christians ignore their culture for the sake of a homogenized super Christian culture? Does this so-called "Christian culture" eradicate the distinctiveness of ethnic culture? Barbara Frye argues:

\footnotetext{
'Hiebert, "Culture and Cross Cultural Differences in Mission," 367.
} 
Our children need to feel that their Christian culture is a "superculture," the culture beyond their Native American, Hispanic American, African American, EuroAmerican, or Asian American culture. It needs to be the culture beyond their national heritages, an American (prefix-free). This identity with their Christian heritage is not a replacement of their ethnic identity, but rather an expansion of it. Their color may be Red, Yellow, Black, or White, but their enduring color is Christian, for this is their eternal culture. It is the tie that binds and will bind when all else is left behind. ${ }^{1}$

Frye argues that our Christian culture does not replace our ethnic culture. The gospel informs and critiques culture. The gospel speaks to and speaks through culture.

At the very core of Seventh-day Adventist eschatology, missiology and ecclesiology is the message of the first angel in Rev 14. The Advent Movement sees itself as the very embodiment of the angel carrying the everlasting gospel to every nation, kindred, tongue and people. The gospel is to break down every barrier in order to reach the world for which Christ died to redeem. Rev 14 recognizes that the gospel will not have completed its mission until it reaches every culture, sub-culture, lingual group, and ethnicity. Jesus affirmed this when He declared, "This gospel of the kingdom shall be preached in all the world, as a witness unto all nations, then shall the end come" (Matt 24:14). Therefore, there is an assumption that culture would not only exist until the end, but also that the Church must work with it and through it until the end.

Second, in the text of Rev14:6, 7, the angel not only carries the everlasting gospel to every nation, kindred, tongue and people, but also the angel carries the command, "and worship Him that made the heaven and earth, the sea, and the fountains of waters."

Worship is the act of adoration and praise of the Creator. The Bible affirms that worship is the primary function of the creature toward the Creator. The song of the twenty-four

\footnotetext{
${ }^{1}$ Barbara Frye, "Diversity and the Family Forum," in Make Us One: Celebrating Spiritual Unity in the Midst of Cultural Diversity, Removing Barriers, Building Bridges, ed. Delbert W. Baker (Boise, ID: Pacific Press Publishing Association, 1995), 150.
} 
elders rings, "Thou art worthy, O Lord, to receive glory and honor and power: for thou hast created all things and for Thy pleasure they were made and created" (Rev 4:11). Worship cannot be forced or scripted. It must be an authentic response by the individual to the divine initiative; it is an authentic expression of the thoughts and feelings of the worshiper. Thus, in order for worship to be a meaningful act, it must be done in the language and idiom meaningful to the worshiper. Worship, therefore, is expressed through culture. Paul Tillich remarks, "The form of religion is culture. This is especially obvious in the language used by religions. All functions of man's spiritual life are based on man's power to speak verbally or silently." This should not mean that worship is to be culturally bound, but it is culturally expressed.

Because culture is a given and it is to be with us, then we must accept that culture, while not the source of worship, is the medium of worship. So, to believe the Christian culture eradicates the distinctiveness of ethnic culture is to limit the opportunity for legitimate worship, the object of the gospel. Therefore those who believe that unity eradicates ethnic cultural distinction must be wrong because oneness cannot run contrary to the mission of Christ and the Church which is to lead fallen man back to the worship of the true Creator. Oneness cannot possibly mean the curtailing of worship by removing the vehicle of worship.

Culture is the mediator of the gospel and must never be confused with the gospel. Failure to make that distinction leads to a ghettoized theology and a fragmented church based upon tribalism on the one extreme, or a theology that leads to syncretism on the other extreme. When culture is baptized, then the danger is making culture the message.

\footnotetext{
${ }^{1}$ Paul Tillich, The Theology of Culture. (New York: Oxford Press, 1959), 47.
} 
Heibert correctly assesses, "A failure to differentiate between the Biblical message and other messages leads to a confusion between cultural relativism and Biblical absolutes." This is cultural idolatry and cultural imperialism that masks as Christian evangelism. The object of the gospel is not to make people like us, but to lead them to Christ who can make them like Him. The gospel cannot be used to validate tribal notions or ethnic identities. The gospel transcends tribe. If the gospel goes to every nation, kindred, tongue, and people, then it must be greater than any single culture and even greater than all cultures combined. This has great implications for the concept of oneness.

Kubo writes:

The Adventist gospel should transcend the barriers of language, race, color, and culture. In Paul's words, "For in Christ Jesus ye are all children of God through faith. And as meant of you as were baptized into Christ, have clothed yourselves with Christ. There is no longer Jew or Greek, there is no longer male or female: for all of you are one in Christ.' (Galatians 3:26-28). We need to remember that we do not belong to the First, Second, or Third World, but to a new world, a new race, the Fourth World, where members from First, Second, and Third Worlds as equal members. Thus Paul, writing in Ephesians 2: 14, 15 says that Christ 'is our peace; in his flesh he has made both groups into one and has broken down the dividing wall, that is the hostility between us'.... He has created unto himself one new humanity in place of two making peace. ${ }^{2}$

Jesus, speaking of the oneness that He has with His disciples, says in John 17:16, "They are not of the world, even as I am not of the world." Jesus calls His disciples into a mystical union that transcends all world systems, all world cultures. This otherworldliness does not deny the existence of the world; rather it liberates the disciples

\footnotetext{
'Heibert, "Culture and Cross-Cultural Differences in Missions," 337.

${ }^{2}$ Sake Kubo, The God of Relationships (Hagerstown, MD: Revièw and Herald Publishing Association, 1993), 44.
} 
from being bound to it. In its place, He provides His worldview, and His modus operandi.

This oneness with Christ allows individuals to move past both ethno-relativism and ethno-centrism into Christo-centrism. Cultural, ethnic or class idolatry is set aside for the purpose of the worship of the Creator. The dividing wall of racism and classism crumbles and gives way to mutuality, reciprocity, commonness of purpose, recognition of essential equality, and respect. Color and class consciousness pale in the light of Christ consciousness. Notions of supremacy give way to the practice of equality. There is a stark realization that Christ died for humanity so as to create a new humanity, a humanity not judged by the color of skin, caste or class but by the content of character formed by Christ and forged into the one divine image of Christ. Caste and class become irrelevant in terms of salvation, for all must enter into the same Door, Christ.

\section{Summary}

In the development of ministry approaches to the Black middle class, theology must inform methodology. Acts suggests that churches in transition must be attentive to possible class and ethnic conflict and that leadership must be quick to respond with interventions appropriate to the context.

James teaches that class tensions may arise in an ethnically homogenous church. So the methodology of James (1) does not ignore class differences, (2) recognizes that each class is susceptible to classism, and (3) therefore each class must be confronted with their class specific sins and called to their new status in Christ.

Ellen White asserts that class is a social construction and an adaptation because of sin. She affirms that the removal of class and ethnic distinction was part of the ministry 
of Christ. She calls the church to realize the responsibility to reach every class and ethnicity. She does not directly discuss methodology, but her theology of missions would necessarily inform methodology.

John 17 informs us that the goal of ministry is oneness with Christ and oneness with other Christians. Oneness is often compromised by linguistic distortion and the imposition of secular concepts into the Christian theological enterprise. But the study of oneness has concluded that oneness (1) is not a denial of cultural differences, (2) recognizes culture as a medium through which to communicate the gospel, (3) is not cultural homogeneity or multi-cultural heterogeneity, and (4) transcends culture. 


\section{CHAPTER VIII}

\section{DISCUSSION: MINISTRY AND PRAXIS STRATEGIES}

The stated purpose of this study is to investigate what social, theoretical and theological factors influence the Black middle class to attend and to affiliate with a church. This section recommends strategies and approaches to ministry to the Black middle class. The recommendations arise from the study thus far of the social, theoretical and theological factors that have been determined to shape ministry. It has been discovered that there are five criteria that must be considered in the formation of ministry strategies to the Black middle class.

First, the approaches to ministry must be culturally appropriate. The ministry must take into consideration socio-economic class. It must recognize the Black middle class as a distinct group with its own cultural idioms, symbols, standards and behavior. It cannot impose a cultural norm or perspective upon the Black middle class.

Second, the approaches to ministry must address the felt needs of the Black middle class. They must recognize that the unique socialization of the Black middle class has produced unique needs. These needs must be heard and respected even if one does not consider them to be legitimate. Because the Black middle class consider them to be legitimate is sufficient to use felt needs as a starting point for ministry.

Third the approaches to ministry must be consistent with biblical principles. The nature of Christian ministry demands that it is consistent with the Authority upon which it 
is founded. Fourth, they must be proffered without prejudice. Racism and classism must not be the guiding principles in the decision of whether to minister, or whether proper resources will be given to facilitate ministry. Fifth, they must foster the goal of oneness. They must call the community toward the biblical ideal unity in diversity.

The recommendations for approaches to ministry in this section fit the above prescribed criteria. They are culturally appropriate in that they arise from the felt needs elucidated in the ethnograph and survey. They are consistent with biblical principles, do not give credence to maintaining racism or classism, and work toward the goal of oneness.

A discussion of strategies and recommendation arising out of the research follows. The recommendations are divided into three major sections: Worship, Programs, and Pastoral Care. In the area of worship, the role of music and preaching is examined. In the area of Program, programs to address relationship skews and gender gap, the achievement gap, and personal finance are discussed. In the area of Pastoral Care, the roles of the pastor as priest, prophet, evangelist and facilitator of the ministry of Christ are discussed.

\section{Worship and the Black Middle Class}

A major component of this study was to ascertain what elements of worship appeal to the Black middle class. Recommendations consistent with the criteria are offered in the areas of music and preaching. 


\section{The Role of Music}

The study showed that 68.9 percent of those surveyed reported that music was an important element in worship. The survey did not ask about style of music preference. However, it is worth noting the significance of music to the worship experience of the Black middle class, so that the worship experience is enhanced by informed choices. About the importance of music in the Black church, Maynard--Reid says:

It is impossible to "have Church' without good music. In the African-American community, music is to worship as breathing is to life. So important is music (particularly vocal music) to the worship service that it has been said it is impossible to "have church' without an outstanding sermon, but not without good singing. Some say that "a sermon ain't nothing but a song."

Music is possibly the most permanent characteristic of the heritage Blacks brought from Africa. Thus a study of their music "is in essence a study of how

Black people 'africanized' Christianity in America." Black music is also perhaps the most vivid conveyor of the social and spiritual struggles of a people in a strange and hostile land.'

The selection of music for worship often creates much tension in the church. This may be even truer for churches in transition that are seeking to bridge cultures and classes. How does the church maintain its musical traditions while seeking to incorporate the tradition of the Black middle class? In seeking to minister to the Black middle class, the White church in transition would do well to incorporate music from the AfricanAmerican tradition. This does not mean that the church must ignore all other musical traditions. Most African-American churches sing both Handel's "Messiah" as well as Andre Crouch's "To God Be the Glory." Traditional gospel hymns like "What a Fellowship," "Blessed Assurance," "At the Cross," "Power in the Blood," "Pass Me Not O Gentle Savior," "Just as I Am," "Come Ye Disconsolate," "What a Friend We Have in Jesus" and "Nothing but the Blood" are favorites in the Black church; they are much

\footnotetext{
${ }^{1}$ Maynard-Reid, 67.
} 
beloved in the White church and speak to the heart regardless of class. But in addition to this, many White churches scarcely realize that some of the popular tunes sung in the church come out of the African-American tradition such as, "Let Us Break Bread Together on Our Knees," "This Little Light of Mine," "We Are Climbing Jacob's Ladder," "Amen," "There is a Balm in Gilead," "Go Tell It on the Mountain," and "Swing Low Sweet Chariot." The point is that there is much common ground for churches in transition.

\section{The Role of Preaching}

This study shows that for the Black middle class, the preaching of the Word of God is central. It out-ranks music, prayer, and worship participation. Ninety-two percent report that biblical content of the worship service is very important or essential and $\mathbf{8 0 . 2}$ percent report that the ability of the preacher is important or essential. What are the implications of these findings on preaching to the Black middle class?

The Black sermon has traditionally been the practical outworking of the theological enterprise. It has been practical theology in that it directly addressed the hearer's life situation. It is embedded theology comprised of what Black people have learned about faith and God through encounters and experiences whether formal or informal, planned or unplanned and communicated through praxis, mission, witness, and spiritual disciplines. ${ }^{1}$ The Black church has traditionally relied upon a preached theology. ${ }^{2}$ The sermon is born from experience and it speaks to the hearers' most

\footnotetext{
Press, 1996), 13.

' Howard W. Stone and James O. Duke, How to Think Theologically (Minneapolis: Fortress

${ }^{2}$ McMickle, 26.
} 
fundamental needs, addresses their existential concerns, interprets and describes a framework for understanding the world. Dolan Hubbard believes that "the outline of the course of African American sermonic tradition is central to the creation of Black identity. .. The African American sermonic tradition is grounded in a self-consciously shared vision."1

If the above authors are correct, and the Black sermon is grounded in a shared experience, then what happens when the experience has changed for a significant portion of the Blacks in America? Does the new situation of the emergence of a Black middle class demand a new Black theology? How does the preacher bridge the gap between his middle class parishioners and his lower class parishioners? What traditional historical language and cultural cues are still significant and meaningful and which ones are not? Are the old motifs anachronistic? Does the emergence of a new class demand also differing stylistic approaches to sermon delivery? These are certainly questions that the preacher must ask.

Recently, as I sat in a church listening to a Black preacher address his audience, he made several statements that demonstrated his assumptions about his audience. "We never had much; we don't have much now; but as long as we got Jesus, we don't need nothing else." He went on to say, "The problem in the church today is that we got too many educated fools." An analysis of his statements demonstrates that he assumes that his audience has grown up in poverty and assumes that they are still poor and that they are uneducated. While this may have been a safe assumption forty years ago, it may not be a wise assumption today. Imagine what must have been going through the heads of his

\footnotetext{
' Dolan Hubbard, The Sermon and the African American Literary Imagination (Columbia, MO: University of Missouri Press, 1994), 19, 20.
} 
middle class members. 'Is he saying that I am not welcome in this church?' 'Is he invalidating my experience in order to validate someone else's experience?' 'If educated people are the problem in the church, then upon what data does he base his assertion?' 'If educated people were the problem in the church, then would all the problems be solved when the educated people leave?' 'If the preacher were more educated would he have better use of his language and not resort to the use of double negatives, slang and hyperbole in order to communicate his point?'

The fact is that the emergence of the Black middle class in the church in transition will call for new approaches to sermonic preparation and delivery. My bother-in-law, a young middle class business owner with a degree in chemistry, grew up in the traditional Baptist church in the south. Long meter hymns and chants are still practiced there. The preacher regularly uses a theme, which forms the lyrical motif and refrain, for the sermon. The sermon is always topical and seems only tangently connected with the text. Typically, at the end of the sermon, he will do a stylized "hoop" of sing-songy grunts and moans. It is a rich tradition steeped in the history of the slave hush arbor of slavery days. Even though my brother-in-law grew up in that tradition and affirms its importance, he now feels alienated from it. He and his young middle class family are involved in the church, and have a growing relationship with Christ, but he attests that he has grown weary of the preacher's style. "I want to know what he is saying. Grandmamma and her old friends get all happy off of that stuff. But I want to hear him talk to me from the Bible about the concerns I have." His comment does not seem atypical. He is calling for a theology that transcends his experience while addressing it. He wants a religion that is sensitive to his needs but faithful to the biblical revelation. In essence, he is calling for a 
return to biblical faithfulness that is Christ-centered and ethno sensitive. The preacher must find a way to bridge the richness of the sermonic tradition with the need of the Black middle class audience to remain true to the biblical narrative.

One of the great hallmarks of Black preaching is that it has always spoken to the times. But how will the Black preacher speak to the times when his audience may have differing interpretations of the times based upon class?

Certainly some of the historical concerns of the larger Black community are still concerns today: discrimination, feelings of alienation from the larger society, social and political justice. The ethnographic data seem to indicate the Black middle class still grapples with issues of discrimination and the survey indicates that 58.2 percent of the respondents indicate that they desire the church to give more emphasis to racial concerns. A Black man driving a Mercedes Benz is likely to be profiled and stopped by the police whether he is a dope dealer or a doctor. ${ }^{1}$ These common concerns of Black people form a point of contact for the classes. And although discrimination, racism and injustice may have slightly different definitions depending on the lens of class, the emotions of fear, humiliation, anger, and disillusionment cut across class barriers. Thus, those issues of common concern can be the bridge used by the Black preacher to bring his poor and middle class members into relationship.

The White preacher speaking to the Black middle class does not have the benefit of the Black experience. He cannot speak the embedded theology from a point of personal reference. But, the Whites preacher may sensitize herself to the issues and concerns of this class by conducting demographic and ethnographic studies of one's

\footnotetext{
${ }^{1}$ Kenneth Meeks, Driving While Black, Highways, Shopping Malls, Taxicabs, Sidewalks: What to Do if You Are a Victim of Racial Profiling (New York: Broadway Books, 2000).
} 
community, region and state similar to the one in this study. This study showed that the Black middle class is concerned about family, health, personal finance, and substance abuse. The White preacher must sermonically grapple with these issues through the Word of God. When the presentation of the Word culturally is sensitive it can speak through culture to culture.

All preachers addressing the Black middle class must be aware that preaching is an oral art and not just a theological polemic. Because Black preaching was given birth in the oral traditions brought from Africa and then honed in the "invisible institution' during slavery, Black preachers have become exceptionally skilled in sermonic delivery. White preachers seeking to win the Black middle class would do well to study the art of Black preaching as it would form a significant cultural bridge for their listeners.

Please note that although this study indicated "Biblical teaching" as the most important factor in choosing a church (90.4 percent), it rated "the quality of the sermons" as the second most important factor ( 81.2 percent) and it rated the ability of the preacher as the third most important element in worship ( 80 percent). This indicates that style is important but not all-important. Indeed, the Black middle class responds quite favorably to both the fiery preaching style of T.D. Jakes and the conversational didactic style of Frederick Price.

Some notable White preachers who have developed a style with which the Black hearers respond are Joyce Meyers, Rod Parsly, Joel Osteen, and in Adventism, Ron Halverson. But one cannot simply mimic the style without including the substance of Black preaching that speaks to the existential reality of this class. For example, John Hagee has a powerful sermonic delivery style, but his message grounded in a 
conservative political agenda is not well received by a Black audience. The sermon must be rooted in Scripture made relevant to the receiver. But the data speak loudly that substance is more important than style.

\section{Programs}

\section{Personal Finance}

Earlier in this dissertation it was noted that the investment profile of the Black middle class demonstrates less use of professional financial services than Whites. This study suggests that the Black middle class look to the church to assist them with issues of personal finance. Given the fact that 60 percent of all respondents earn less than $\$ 50,000$ in household income, these individuals may lack the history of interface with financial advising and may lack the means to afford it. Eighty-one percent of respondents earning $\$ 20,000-\$ 30,000$ report personal finance as an area of needing emphasis in the church.

But how should this be addressed? If Black middle class church attendees desire assistance with financial management, then the church should consider providing such as a ministry. If one has the knowledge and skill to teach a struggling brother, then it would be a sin to withhold such knowledge. Given the fact that the Black middle class home owner is five times more likely to file bankruptcy than her White counterpart, then it is the duty of the strong to help the weak. ${ }^{1}$ However, if that is the sole focus, then it cannot be spiritual.

\footnotetext{
1 "Injustice Index: The Black Middle Class," May 2004, http://www.drummajorinstitute.org/plugin/template/dmi/44/2369 (accessed 13 February 2005).
} 
The principles of stewardship, or the wise management of the resources entrusted to us by God has long been taught by the Seventh-day Adventist Church. Barna and Jackson identify "Holistic Stewardship" as one of the factors in the development of high impact African American churches. However, their definition of "holistic" focuses primarily upon sacrificial giving and entrepreneurship.'

The biblical concept of stewardship is much broader, more comprehensive and balanced; it includes the wise management of time, talent, the body temple, relationships, and the environment. The focus only upon money leads to what has been identified in James as the sin of lust. The Black middle class has pursued the American dream of obtaining more things in order to have "the good life." But McMickle challenges his middle class congregants with these words, "The 'good life' is what America offers at a price. The 'abundant life' is what Jesus Christ offers as a gift."'2

The ethnographic profile indicates disparity in housing and lending between the Black and White middle classes. Churches in transition may also address some of the inequities in lending patterns. First, a church may challenge local lending institutions to offer competitive rates to all persons moving into middle class neighborhoods. But, be advised that most institutions knowing that it is illegal to have stratified lending practices will never admit to it. A church will have to conduct its own investigation by making inquiry of its members and neighbors. Churches, which have considerable financial clout, can simply refuse to do business with an institution that practices discrimination. Second, a church can develop its own lending institutions. Churches may charter their

\footnotetext{
${ }^{1}$ Barna and Jackson, 149-169.

${ }^{2}$ McMickle, 88.
} 
own credit unions ensuring not only fairness in lending, but also that the funds are circulated within the community thereby creating more wealth. ${ }^{\prime}$

\section{African-American Health}

This study shows that that the Black middle class is very much concerned about health and indeed they should be. AIDS is devastating the Black community. Studies indicate that one out of every five Black middle class persons with jobs have no health insurance. $^{2}$ Indeed if the Black middle class is going to be financially stable, then health issues must be addressed. And while a local church may not be able to rectify the causes of disproportionate numbers of this class without health insurance, a church can provide programs that teach disease prevention and health maintenance. Seventh-day Adventists have always affirmed that the health message is the right arm of the gospel.

\section{Marriage Enrichment}

The ethnographic profile indicated gender disparity in income and education with Black females comprising a larger percentage of the college educated and the professional-managerial class. But by asking if "marital issues" are in need of emphasis in the church, the intent was to discover if marital relations were a subject of much concern. Indeed they were. Three recommendations arise as the result of the data.

First, forums are needed to help the sexes understand the phenomena of the achievement gap and its causes. Both female blame and male apathy are given

\footnotetext{
${ }^{1}$ Gregory J. Reed, Economic Empowerment through the Church: A Blueprint for Progressive Community Development (Grand Rapids: Zondervan, 1994), 103-108.

2 "Injustice Index: The Black Middle Class," http://www.drumamjorintitute.org/plugin/template/dmi/44/2369 (accessed 13 February 2005).
} 
life in the uterus of ignorance. Assumptions, perceptions, and prejudices need to be exposed and unpacked. Dialogue around the issues will not only provide understanding but also create working inter-gender relationships around which meaningful collaboration may result in solution-oriented strategies. Because all of society is now dealing with transition in gender roles and expectations, all churches whether Black or White could create such a forum. What does it mean to be a man or woman today? How have traditional roles shaped our understanding of gender? What does the Scripture teach about gender and how God views roles and responsibilities? These are questions that cut across class and ethnic lines. But we must not forget that our distinct histories and ethnicities help shape our understanding of gender roles. So let me provide one word of caution: the White pastor must be sensitive to the unique set of circumstances facing the Black couple and not be too quick to only ascribe gender-based recommendations without taking the history of race and the Black male into consideration.

Second, marital enrichment ministries are needed to assist couples to work through the issues of disparity of income and education. Not all marital issues arise out of gender, race and income disparity. Marital enrichment ministries will assist the couple with sorting out issues related to gender and income from other issues in the marriage. Many churches have marriage enrichment ministries, and the fundamental biblical principles of healthy marriages are not confined to ethnicity or class. Couples of all ages, classes and backgrounds will find commonality in this most primary of human relationships.

I was recently facilitating a retreat for young Black professionals when the subject of Black male underachievement was raised. Of the young professionals present, about 
80 percent were female; all were unwed. The young women castigated young Black males as being "lazy," "no good," "unmotivated," "unsuccessful," and therefore "not marriage material." Although all of these women had been able to transcend the stereotypical roles for women, they nevertheless held some very traditional values regarding relationships. They remarked that the man should out-earn the female. Some remarked that they could not respect a man who earned less and would never date a man who did not have at least a college degree. The few men present attempted in vain to defend of Black men by rehearsing the additional pressures faced by Black males in America. ${ }^{1}$

\section{Career Development}

The church must address the issues of access to professional employment for Black females at the lower income level and Black males. It is one thing to describe that disparity exists, and quite another to redress the disparity. Professional men and women could create career development programs to recruit Black males into the professions, and then mentor them in the professions. Such programs could provide basic assistance with job readiness, resume writing, understanding corporate culture, and networking. This will be easier to accomplish in the Black middle class church than in the White middle class church. Black churches have a tradition of providing such services, even if that tradition was more informal than formal. But now, the Black middle class church

\footnotetext{
1 See Earl Ofari Hutchinson for a discussion of Black male bashing and media distortion of the Black male in The Assassination of the Black Male Image (Los Angeles: Middle Passage Press, 1994), and see Haki R. Madhubuti, "Five Most Often Used Excuses Black Men Give Black Women," in Black Men, Obsolete, Single, and Dangerous? The African Family in Transition, (Chicago: Third World Press, 1990).
} 
must be more intentional in its efforts and therefore more formal in its approach if it would strategically address the gender gap in the Black middle class.

The White church may be more challenged in setting up such programs to assist Black males. It may be seen as another affirmative action program rather than as a means of healing the gender skew in Black relationships. Also, because of the large increase of White females into the same job market, which also experience gender income disparity, there may be a tendency in the predominantly White middle class church to focus more on gender parity for White females, than for Black males. A church that is wise however will address issues of injustice and inequity wherever they arise and will be proactive in healing the wounded.

\section{Educational Enrichment}

The ethnographic profile indicates that the children of the Black middle class perform worse on standardized test scores than their Black lower class counterparts. Most Black middle class parents may not be aware of the achievement gap. They may not know that children of Black middle class homes where parents are educated are actually beginning to score lower on standardized tests than children from homes with less education.

However, this study does show that the Black middle class parents are very much aware of their need for parenting assistance ( 81.4 percent). This study also reveals that it takes two working parents to attain and maintain middle class status for a family of four (65 percent of those earning between $\$ 40,000$ and $\$ 50,000$ were married). Middle class parents, who must work long hours to maintain their newly found standard of living, 
may have less time and resources to devote to academic enrichment activities for their children.

At the upper and lower ends of the Black community there are interventions that do not exist for the middle class parent. Upper class Blacks believe in enrichment programs, clubs, and affiliations that will provide their children with the best opportunity for academic success. Some urban churches in poor neighborhoods are able to obtain grants and other funding for after-school programs that are accessed according to need. The church may assist the middle class family in the development of after-school programs, camps, and clubs that will round out the students' educational experience while providing a social network that encourages academic success.

One such enrichment program offered by the Seventh-day Adventist Church is called "Pathfinders." The Pathfinder program, which is similar to the Boy and Girl Scouts, is a skill- and knowledge-based character formation club designed to promote the harmonious development of the mind, body and spirit. It is open to children of all classes and ethnicities. The required uniform alleviates class status. Promotion in the organization is based upon the acquirement of skill, which is aptly appropriate to the real world in which the Black middle class child will enter. The outdoor camping and recreational activities expose the urban and new suburban Black middle class children to a wide variety of experiences in nature. Emphasizing teamwork, children of various cultures and backgrounds are given opportunity to develop meaningful mutual and reciprocal relationships as they work toward a common mission. Regional, national and international "camporees" allow the participants to witness the diversity that exists in the body of Christ. Parents are urged to become partners in the process, thereby giving them 
an opportunity to spend significant time in the development and enrichment of their child. But the benefit of parental involvement is not just to the parent/child relationship. Parents of all backgrounds may come together, and come to know each other as they work toward the enrichment of their children.

\section{Pastoral Care}

The recommendations in this section are designed to assist the practitioner of pastoral ministry. The role of pastor in ministry to the Black middle class is divided into three responsibilities: the pastor as priest, the pastor as prophet and the pastor as evangelist. Each of these roles will be explored in the light of the study, giving consideration to the ethnographic profile and the survey results.

\section{The Pastor as Prophet}

Our survey queried, "What is the role of the pastor?" Some 56 percent thought that the role of a community activist was very important or essential. While we used the term "community activist," others may choose the term prophet. This is not to imply that the pastor is the equivalent of the biblical prophet who received direct revelation from God. Rather the term is used in the literature to mean one who must speak the word of justice, call sin by its right name, and call people into obedience to the will of God. Walter Brueggenmann delineates the importance of the prophet in serving as both criticizer of the existing order and the energizer of persons and communities, moving them back to the central issues of their faith-those which, by providing an alternative 
consciousness toward the world, supply the community of believers with a new vitality and understanding of their own wholeness and possibilities. ${ }^{1}$

The role of "the prophet" has always been valued in the African-American church. Where bigotry existed, in whatever form it took, it was the responsibility of the Black preacher, the prophet, to denounce it and call the people back to the truth.

With the emergence of the Black middle class, there has come a corresponding resurgence of classism. This present study shows that some of the more highly educated Blacks are the least responsive to the needs. Classism has always been a part of the Black experience in America and a part of the Black church. It was in the interest of the master to create a two-class system, the house servant and the field hand, so as to provide a buffer between him and chattel that he must control.

Often skin color was used as the distinguishing mark between the two classes. After the dismantling of slavery, mulattos had greater social and upward mobility, and thus protecting the bloodline against 'dark blood' became important to lighter-skinned Blacks who wanted to maintain their status of privilege. ${ }^{2}$ But in the last forty years skin color is less significant as a class marker among Blacks. Davis recounts:

In the 1960's, growing Black pride brought the lighter mulattoes into an even closer alliance with Blacks in general than the Black Renaissance of the 1920s had produced

.... By the mid-1970's the devaluation of the prestige of light color had influenced marital choice and the class structure of the Black community significantly. Lightness had become less valuable as the criteria for moving up from the lowerupper class to the aristocratic upper-upper class. ${ }^{3}$

\footnotetext{
${ }^{1}$ Stewart, 21.

${ }^{2}$ For a fuller discussion on the issue of skin color and social mobility see James F. Davis, Who Is Black? One Nation's Definition.

${ }^{3}$ Ibid., 74, 75 .
} 
Skin color is no longer the prerequisite for upward mobility, rather it is education and wealth. The new middle class Black boasts the pedigree of college education and a paycheck that separates him from his poorer sisters and brothers. Social distance is maintained by address, dress, vocabulary, and the exclusivity of social circles.

The Black pastor therefore must take a prophetic stance not only speaking out against the societal evil of classism, but also reminding her middle class parishioners that they too have been outcast, brought in, and therefore have an obligation to their brothers and sisters left behind. She must critique selfishness and exclusivity, and she must call the community of believers into reconciliation, mutual respect, and true fellowship as children of God.

It will not be easy to be prophetic. The Black pastor has now become a member of the middle class. By education, dress, vocabulary, and address she identifies with the middle class. Will she be able to maintain objectivity or will she lose the ability to be prophetic by having been compromised by the system that she must criticize? Certainly she does not have to be compromised. Isaiah, Nathan, Daniel, and Paul were all of the higher classes. Yet their identity was not rooted in their class but in their relationship with God. Their commitment was not to maintain the social order, but to usher in the kingdom of God that disrupts all human social convention.

But it must be asked, "Is the prophetic role the sole responsibility of the Black pastor alone? Is there not also a prophetic message to be given by the White pastor during this time of transition? Just as the prophet Isaiah declared, "Cry aloud and spare not. Shew the house of Israel their sins" (Isa 59:1), so it is that the White pastor must be willing to challenge the status quo and to challenge the White member to move beyond 
the comfort of his homogenous unit. The prophetic role requires speaking out against class bigotry wherever and whenever it appears whether in church elections, allocation of resources, theological assumption, or methodological approach. Not only that, the White pastor must be as willing to call the Black member into account on his abandonment of the underclass as he is to call the White member on his ethnocentrism. Carlyle Fielding Stewart writes:

The pastor must not only clarify but creatively confront the people and problems both he and they face. Often in discussing pastoral care, we avoid using the language of confrontation. It seems harsh, almost incongruous with the role of pastor as sympathizer and shepherd. Yet, if we are to seriously consider the elements of prophetic church growth, the pastor must exemplify courage in creatively confronting and addressing the serious problems that arise in the lives of parishioners and the church. God help the pastors who are afraid to take on critical problems for fear of getting their clothing soiled and their hands dirty. ${ }^{1}$

The Pastor as Priest

The plight of the African in America has morphed and shifted over the centuries.

There are at least five major historic ecclesiastical shifts:

1. Embarkation on American soil and the practice of African Traditional Religions

2. The "Invisible Institution," the slave church on the plantation

3. The rise of the African-American denominations in America

4. The era of emancipation, reconstruction, and mission

5. Urbanization and Social Activism. ${ }^{2}$

\footnotetext{
${ }^{1}$ Stewart, 85 .

${ }^{2}$ Fulop and Raboteau delineate these historic categories in Timothy E. Fulop and Albert J. Raboteau, eds., African American Religion: Interpretive Essays in History and Culture (New York: Routledge, 1997).
} 
In each of these eras the Black preacher has been both the translator of the times to his people and the transformer of the times for his people. A priest is a mediator between the spiritual and the natural world. He must represent man to God and he represents God to man. He interpreted the meaning of God to the people in their context and he interpreted the meaning of the world in the light of God's revelation.

The ethnographic profile in this study suggests that perhaps a new and sixth major ecclesiastical shift is taking place: the rise of the Black middle class and the suburbanization of the church. This shift may prove as historic as the previous five.

On the plantation, the slave preacher was often the one who forged the bridge of understanding for his people. Every culture is interpreted by its metaphors, symbols, language, traditions and artifacts. The African immigrant, if he were to survive in a new environment, must negotiate that new culture, and interpret, and interface with that new culture. He needed a priest, a mediator. The slave preacher possessed the keen insight to interpret the new culture and to translate it to the old culture. In that he was a translator of cultural metaphors and idioms, then the slave preacher would have been the one to rise to prominence in the New World.

There is still a need for the priest. The Black middle class is now very educated. They are able to read the Bible for themselves. Some have been trained in the finest institutions of higher education in the land. But, the training they have received is undergirded with secularism, skepticism, atheism, nihilism, egoism, scientism, materialism, and existentialism. Thus, when they sit to read and interpret the Word of God, they bring secular philosophical presuppositions to their interpretation. The prosperity preaching that is so attractive to the Black middle class is born of poor exegesis and secular values, 
masking itself as authentic Christianity. If the preacher is to guide his people, then he must be versed. He cannot critique the philosophical underpinnings of false theology if he does not have at least a rudimentary understanding of them. And if he does not have a rudimentary understanding of them, then his so-called educated members will view him as ignorant and therefore irrelevant. If the Black pastor does not step forward to fulfill his historic role as priest now, he runs the risk of irrelevancy, and being relegated to the ash heaps of history while the people run to the new mediators and interpreters of the age reporters, politicians, courts, talk radio hosts, brokers, scientists, BET, MTV, Hollywood, Oprah, hairdressers, taxi drives and barbers.

The results of this study indicate that the Black middle class persons surveyed considered the role of "Counselor/advisor" above every other possible response ( 81.7 percent), even the ability to preach. A counselor is a person who helps the client interpret the world about them and their place in it. These days, psychological counselors have become the new priesthood, constructing meaning, deconstructing myth, and providing rationales. It is ingrained in our American culture to solve almost every human dilemma through some sort of psychological intervention. Because of this, many pastors seek the validation for their ministry in obtaining a degree in counseling.

While there is a need for counselors, there is still a need for the biblically styled priesthood, a person to represent God to the people and the people to God. This is not at all to suggest a priesthood that undermines the High Priest in heaven, nor do I suggest a priestly class. Rather, it does suggest that the pastor step into his/her God-given role as the interpreter of the times. The people crave answers to life's perplexities and it is the role of the pastor to facilitate their finding answers in the Word of God. 
The challenge before the preacher, both Black and White, in the new millennium is great. He must be conversant with the times without being co-opted by the times. $\mathrm{He}$ must build bridges between the classes and ethnicities in the community while simultaneously building bridges of understanding between the prevalent secular humanism and the divine revelation.

\section{The Pastor as Evangelist}

This study is the first to ask the Black middle class, "What forms of evangelism are most effective?" Neither Barna and Jackson, nor McMickle have asked this question. The answers given to the question by the Black middle class persons surveyed may not represent the most effective forms, but forms with which the survey population perceived as being most effective.

This study has shown that the Black middle class persons surveyed were least favorable to the traditional forms of public evangelism as practiced by Black Seventh-day Adventists, such as outdoor tent evangelistic meetings ( 35 percent). This does not pose a challenge for most White Seventh-day Adventist churches that have long since abandoned the "tent crusade." It may pose a problem for many Black Seventh-day Adventist congregations who have traditionally relied upon the tent meeting as its primary form of evangelistic outreach. The following example illustrates how class may influence the choice of evangelistic method.

There seemed to be general excitement in the church over the upcoming evangelistic endeavor. Committees had been formed and assignments had been made; a location had been secured; and the date had been set. All seemed to be on track until the 
evening of the church business meeting when the simmering discontent exploded. The middle class members voiced their concerns.

"Why are we pitching a tent in order to win souls?" a member asked.

The pastor responded, "Because tents have been proven a successful soul winning method."

The member retorted, "Well I'm not going to walk through dirt and mud to sit up in some hot tent just to hear a sermon. And then pastor, do you really expect us to use port-o-johns? I have many friends who I would like to join the church, but I don't feel comfortable bringing them to a tent."

Another member blurted out, "Why do we keep going back to the housing projects? Can't we go to a different neighborhood? We keep bringing in all the poor people in here and they don't contribute anything to the church; instead they take more resources out."

Struggling to maintain his authority and credulity, the pastor sniped back, "If it were good enough for E. E. Cleveland, then it is good enough for me."”

The scene is probably repeated dozens of time in many Adventist churches as they prepare to do evangelistic outreach to the "community." This example typifies the complexity of attempting to do evangelism in this era of transition. Clearly, the members exhibited a class bigotry and snobbery. But also, clearly the pastor may have been out of touch with the other effective means of evangelism. The conflict is not about whether evangelism should take place but how it should take place. Is the method relevant to the population? Shall the church open market the evangelistic approach using "the whosoever will, let him come" approach? Or, shall the church target market and focus its 
energy in order to maximize our resources by attempting to win only people like themselves? Shall evangelism be inclusive of various classes or exclusive?

The challenge for the pastor and the church in transition is to recognize the in the complaint of his middle class member is an unmet need to be validated and to be recognized as a person of worth. The member may be saying that, by validating those who are like me, you are validating me. But second, the pastor must realize that the member is communicating that it is important to contextualize the gospel to his class in order to reach his class. Justifications and defenses of methodologies are just as inadequate as the justifications and defenses of class bigotry.

Seventy-three percent (73.5 percent) of Black middle class persons surveyed reported that "one on one Bible study" was the most effective form of evangelism. The third most frequent response was "small group evangelism" (60.4 percent). As noted earlier in the ethnographic profile, the Black middle class appear to feel alienated on their jobs and frequently misunderstood by society. There appears to be a desire for more focused and personal approaches to evangelism.

A most surprising finding of this study was the fact that 73 percent of the respondents reported that they would consider joining a non-African American church. Traditionally the Black middle class living in the suburbs has commuted to the Black church in the city rather than attend a predominantly White church where they may not be welcome. However, this study demonstrates that there is a considerable percentage of the Black middle class who desires to worship in a neighborhood church. Thirty-seven percent indicate that the nearest church in their denomination would be an important factor in joining a church. Note that they did not say that a non-African American church

\footnotetext{
${ }^{1}$ Earl E. Cleveland is a noted Seventh-day Adventist, international evangelist, teacher, and author.
} 
would be their preference. Many African-American Christians love to worship in their own cultural idiom. But the survey does demonstrate that the Black middle class is open to multi-cultural church.

One can conclude from the data that if (1) the Word is being expounded, (2) the preacher can preach, (3) the worship service is inclusive, and (4) the church is sensitive to the needs of this population, then it is possible for the White church in transition to win them. Conversely, one may also conclude that if those same factors are absent in the Black church, then it is possible for the Black church in transition to lose the Black middle class.

The Pastor as Facilitator of Ministry:

Pointing to Christ

The Black pastor has always been at the forefront of providing for the social, physical, political, and spiritual needs of his parishioners. It was the Black clergy and the Black church that provided job training, temporary food and shelter through the settlement houses that received Blacks moving to the north during the "great migration" at the beginning of the twentieth century. Throughout the last century churches have operated soup kitchens for the hungry, shelters for the indigent, and day cares for the children. But as we emerge into a new century, the church is challenged to offer new ministries to meet the needs of the Black middle class. And what are these new needs? Certainly, it is not the need for clothing and shelter. It is not the need to open a bank account or to obtain gainful employment. They have larger homes and bank accounts but still feel unsatisfied. They have learned, like their White counterparts, that money cannot buy happiness or security. Rather, their needs are psychic and spiritual. This study 
indicates consistently the importance of prayer (81.7 percent), one-on-one Bible study (73.5 percent), and biblical teaching (90.4 percent) as important to this class. It is the need to make sense out of the nonsense of life and to find significance in a society that continues to devalue one's worth. McMickle states:

Ministry to the Black middle class, while it must challenge them to be mindful of and responsive to the need of Blacks in the underclass who remain in the inner cities, cannot stop there. It cannot be assumed that racism is reserved for those who live in poverty, whether in the physical confines of urban ghettos or the equally impoverished rural areas throughout the American South. Those who minister to the Black middle class must be sensitive and responsive to the pains that racism still inflicts upon upwardly mobile Black people who may have been deceived into thinking that their economic and employment status had finally placed them beyond the reach of racist words and deeds.

Black middle class persons are hurting. They feel the pain of the exploded myth "Work hard and you will be successful.". Cose in his book, The Rage of the Privileged Class, identifies what he calls "A Dozen Demons" that plague the Black middle class. ${ }^{2}$ Cose does not mean that these demons are the fallen angels spoken of in the Bible. Rather they are psychosocial stressors that daily confront Black middle class persons. Each of the dozen demons identifies a reality in the mind of the Black middle class and therefore a felt need.

The pastor may minister to the Black middle class by helping them to see beyond their felt need to the fulfillment of their ultimate needs met in Christ. Felt needs are earthly assessments. Ultimate needs recognize the reality of the earthly, but find their fulfillment in the heavenly. If the pastor allows her parishioners to focus only on their felt needs, then their tendency will be to look inward for solutions to the human dilemma.

\footnotetext{
${ }^{1}$ McMickle, 19.

${ }^{2}$ Cose describes "the continuing relevance of race" in the workplace, and its effects on the Black middle class worker, in chapter 3 of The Rage of the Privileged Class.
} 
Neither inward reflection nor social action is able to satisfy the deepest longing of the human soul for purpose. Political agendas, psychological counseling, economic parity, and forensic justice cannot provide lasting satisfaction. True fulfillment is found only in a relationship with Christ. Christ alone provides not only the sustenance in this present evil age of social injustice, psychological trauma, and economic disparity, but also a transcendent hope. He holds out before humanity a new heaven and a new earth wherein dwells righteousness. He assures humanity that whosoever will may enter into that kingdom without regard to ethnicity or class. And $\mathrm{He}$ assures that there in that kingdom every human longing is satisfied and all shall hunger no more.

Table 19 demonstrates the so-called demon, the felt need as a result of the demon, and how the ultimate need is met in Christ. The ultimate needs are scripturally based, not socially mediated. They are the mirror opposite of the felt need in that the felt need is that for which the individual longs. The ultimate is what Christ provides. The felt need can never be satisfied from within. Christ imparts from without that which humans can never generate from within. Felt needs pose the dilemma; while the ultimate suggests that an absolute solution can be found.

The pastor ministering to the Black middle class has a choice. She may either continually remind her parishioners that they are second-class citizens, or she may choose to remind them that they are first-class saints. The former locks them into a hopeless world system. The latter elevates them to their true position, sitting with Christ in heavenly places, as fully enfranchised children of the King. Only from that vantage point may one have both the spiritual fortitude and the moral authority to address the evils of this fallen world system while beckoning others to the heavenly kingdom. 
TABLE 19

\section{ULTIMATE NEEDS MET IN CHRIST}

\begin{tabular}{|c|c|c|}
\hline Dozen Demons & Felt Need & $\begin{array}{l}\text { Ultimate Need Met } \\
\text { In Christ }\end{array}$ \\
\hline 1. Inability to fit in & $\begin{array}{l}\text { To be free to be one's } \\
\text { authentic self }\end{array}$ & $\begin{array}{l}\text { Known and called by Christ } \\
\text { Isa 43:1-3 }\end{array}$ \\
\hline $\begin{array}{l}\text { 2. Exclusion from the } \\
\text { club }\end{array}$ & To be included & $\begin{array}{l}\text { Brought nigh in Christ } \\
\text { Ephesians } 2: 13\end{array}$ \\
\hline 3. Low expectations & $\begin{array}{l}\text { To be held to an } \\
\text { equal standard }\end{array}$ & $\begin{array}{l}\text { Christ no respecter of persons } \\
\text { Acts } 10: 34\end{array}$ \\
\hline 4. Shattered hopes & $\begin{array}{l}\text { To have hope } \\
\text { renewed }\end{array}$ & $\begin{array}{l}\text { Lively hope in Christ } \\
1 \text { Pet } 1: 3\end{array}$ \\
\hline 5. Faint praise & $\begin{array}{l}\text { To be affirmed and } \\
\text { honored }\end{array}$ & $\begin{array}{l}\text { Honored by following Christ } \\
\text { John } 12: 26\end{array}$ \\
\hline $\begin{array}{l}\text { 6. Presumption of } \\
\text { failure }\end{array}$ & $\begin{array}{l}\text { To be seen as } \\
\text { competent }\end{array}$ & $\begin{array}{l}\text { Competence only in Christ } \\
\text { Phil } 4: 13\end{array}$ \\
\hline 7. Coping fatigue & To be renewed & \begin{tabular}{|l|} 
Rest in Christ \\
Matt $11: 29$ \\
\end{tabular} \\
\hline 8. Pigeonholing & $\begin{array}{l}\text { To be given equal } \\
\text { opportunity }\end{array}$ & $\begin{array}{l}\text { "Whosever will" invitation of } \\
\text { Christ } \\
\text { Rev 22:17 } \\
\end{array}$ \\
\hline 9. Identity troubles & $\begin{array}{l}\text { To have one's self } \\
\text { validated }\end{array}$ & \begin{tabular}{|l} 
Identity in Christ \\
2 Cor $5: 17$ \\
\end{tabular} \\
\hline $\begin{array}{l}\text { 10. Self-censorship, } \\
\text { silence }\end{array}$ & To be heard & $\begin{array}{l}\text { Heard by God } \\
\text { Ps } 77: 1\end{array}$ \\
\hline 11. Mendacity & To be told the truth & $\begin{array}{l}\text { Christ the Truth } \\
\text { John 14:6 }\end{array}$ \\
\hline $\begin{array}{l}\text { 12. Guilt by } \\
\text { association }\end{array}$ & $\begin{array}{l}\text { To be judged on } \\
\text { one's own action }\end{array}$ & $\begin{array}{l}\text { Judged by Christ on own works } \\
\text { Rev 22:12 }\end{array}$ \\
\hline
\end{tabular}


CHAPTER IX

SUMMARY, RECOMMENDATIONS, AND CONCLUSIONS

\section{Summary}

This study has sought to uncover the theoretical frameworks, theological implications and sociological factors which inform ministry to the Black middle class in churches in transition. This study used a multi-method qualitative approach to explore and to describe both the challenges facing the Black middle class, and the challenges facing the churches seeking to minister to this class. Each aspect of the study question has been given consideration.

Theoretical frameworks were examined to see their appropriateness for informing ministry approach. Mission theory grounded in anthropology and sociology was examined. Finally, the homogenous unit principle was examined in the light of the research question.

Three social theory frameworks have been examined: cultural equivalent, cultural deviant, and cultural variant. It was discovered that of the three social theory frameworks, the cultural variant offered the best approach to interpreting the Black middle class. The cultural variant theory allows the researcher to note the differences between the group studied and other groups. Thus the cultural variant theory is helpful in 
developing an ethnograph of a study population. Yet, it was also noted that the limitation of this secular theory is that it cannot factor the reality of sin into the equation or take into account the falleness of all human culture.

Missions theory, which makes use of the social sciences of sociology and anthropology, is useful not only to describe the study group under observation, but also to tailor a ministry approach that is sensitive to the culture. But it is further noted that cultural particularity runs the risk of cultural idolatry.

Theological implications of race and class were examined to determine how theology might inform methodology. A social description method was applied to the examination of biblical passages in Acts and James. The study of Acts reveals that class and ethnic differences were evident in the Early Christian Church in transition and that the leadership of the community moved to implement fair and culturally sensitive strategies to address the threat to unity. James reveals that classism in the church must be confronted with the claims of Christ upon the life and the call into a new status as a member of the Christian community. Literary studies both of the words of Ellen White and the meaning of the term "Oneness" were conducted.

Sociological factors which inform ministry to the Black middle class were uncovered through two techniques. Demographic data and data from historical and cultural sources were compiled to create an ethnographic profile of the Black middle class. It was discovered that the Black middle class is distinct from the Black lower class and the White middle class. It was discovered that the felt needs of this population form a unique ministry challenge and that it is therefore justified to create ministries specific to the population. In addition, a survey of 177 Black middle class persons was 
conducted to ascertain what factors influence their decision to attend or to affiliate with a congregation. This constituted this first such survey of the attitudes, beliefs, desires and values of the Black middle class in regard to church attendance and affiliation. The results of the survey are used to recommend ministry strategies.

\section{Recommendations for Further Study}

The purpose for this study was to examine a major cultural change that has occurred within American society, the burgeoning Black middle class. The possible impact of this class upon churches in transition has been analyzed. The Scriptures have been gleaned for spiritual principles that would inform this method. And, strategies have been recommended based upon this study.

Yet, it would be less than honest to suggest that all of the issues have been covered, and all strategies recommended. Strategies are designed to give only a general direction that may be taken. There is much work to be done to operationalize strategies into programs, which can be measured and evaluated. Further work must be done in this area. Also, the issues of the Black mega-church as a growing phenomena are worthy of much more study than given here. This study did not assess the White church's willingness to receive the Black middle class that seems to be open to worship in a nonAfrican-American church. This study did not recommend models or explore working models. These are all grounds for further study. Yet, it is my hope that this study will be useful, first, to call attention to the challenge of transition and, second, to rally the resources of the Church to meet that challenge. There are at least ten areas to be considered for further research. 
1. The survey may be repeated with a larger pool of participants for greater generalizabilty.

2. The survey was conducted in the southeastern United States. The survey may be conducted in various regions of the country to determine regional differences.

3. The study may be repeated and results reported by denomination to determine the possible correlations between denominational affiliation and responses. Do some denominations respond differently from others?

4. The survey may be given to the Black lower class and the Black upper class to test for statistically significant differences.

5. To determine best practices, several experimental studies may be conducted using the following possible Independent Variables and Dependent Variables:

a. Independent Variables: Denomination, congregation, location.

b. Dependent Variables: Factors which impact decisions to join a church, desired emphases in the church, style of worship, style of evangelism, role of pastor.

6. A survey of non-African-American churches may be conducted to determine their readiness to receive the Black middle class and to explore whatever challenges they have faced in their attempts to incorporate the Black middle class.

7. Field observations may be conducted of churches that appear to be successful in the recruitment and retention of Black middle class persons. Memos of observations may be coded. The coding may expand the constructs. Additional notes and data may be used to inform and revise theory and praxis. 
8. Field interviews of pastors may be conducted to code the role of the pastor in successful navigation of churches on transition. What are successful pastors doing? What innovations have been developed in the field but not coded?

9. A program that addresses the findings of this study and implements the recommendations may be conducted.

10. Longitudinal observations are needed to track changes in congregational dynamics in churches where major demographic and cultural transition is occurring.

\section{Conclusions}

This study was not a quantitative study to test a hypothesis. Rather, it was a qualitative study to describe phenomena from which a hypothesis may emerge. This study has confirmed (1) the uniqueness of the Black middle class, (2) the uniqueness of the felt needs of the Black middle class, (3) the desire of the Black middle class to have ministries germane to their needs, and (4) that ministry to the Black middle class must be consistent with Scripture. It is therefore reasonable to conclude that if the four above conditions are met, then the ministry approach will be appropriate to the population and successful in the recruitment and retention of the Black middle class to churches in transition.

Change is inevitable. It will occur whether we are prepared to address it or not.

Besides God, change is the only other constant in the universe. Peter C. Wagner states:

We live in a time when both the degree of cultural changes, and the rate of cultural changes, are accelerating alarmingly. George Barna says, 'There is a great deal of disagreement among sociologists, but they agree that change is happening faster today than ever before. Our culture is reinventing itself every 3 to 5 years. We have new patterns of behavior 2 to 3 times per decade. ${ }^{1}$

\footnotetext{
' C. Peter Wagner, Churchquake: How the New Apostolic Reformation Is Shaking Up the Church as We Know It (Ventura, CA: Regal, 1999), 17.
} 
These new patterns of behavior are not only worked out in society, but also in the church. Cultural change will not only shape behavior, but it will shape theology and ecclesiology. Hopefully, theology will inform behavior, rather than behavior informing theology. The Church is not a human institution; it is a divine institution entrusted to humans. It is not to be shaped by the shifting winds of human culture, but neither can it ignore the winds. The flag blowing in the breeze may shift direction from time to time, but it is never stops being a flag. It always declares what it is and what it represents. And although it blows in the breeze, it is not blown away because it is anchored to the pole that never changes. And so it is with the Church, it may respond to winds of change, but it is never to be blown about by every wind of doctrine, for we have an anchor, Christ and His eternal Word. In the winds of change there, are according to Galloway, "Three Crucial Change Perspectives;" first, eternal truth never changes; second, culture is rapidly changing; third, tools and methods may change. ${ }^{1}$

The eternal truth of the Word of God must inform praxis and mission in the changing culture. The Word of God must anchor theology and inform ecclesiology. The Word of God must challenge all that is, and dictate all that must be, whether the challenge is to classism, ethno-centrism, selfishness, or traditions.

The Bible is clear and unambiguous in the assertion that oneness or unity is the Christian ideal. Rom 12:5 states, "So we, being many are one body in Christ, and every one members of one another." Unity is to be the normative and operational principle in the Church. The church is admonished in Eph 4:3, "Endeavoring to keep the unity of the

\footnotetext{
${ }^{1}$ Dale Galloway, Leading in Times of Change (Kansas City, MO: Beacon Hill Press of Kansas City, 2001), 11.
} 
spirit in the bond of peace." Once again in 1 Peter 3 the Church is charged, "Finally be ye all of one mind having compassion one for another, love as brethren, be pitiful, and courteous."

But the history of the Church confirms that oneness remains an ideal without process to bring it to fruition. Strategies and methodologies may help facilitate change. Nevertheless, strategy, however clever, has never transformed a human heart from being selfish or bigoted. This is the work of the Holy Spirit. Rather, strategy may be used to bring the challenges to light, to call the Church to action, and to remind the Church of its divine calling. 


\section{Appendix}

\section{Survey of Middle Class African-Americans Attitudes toward Church}

I. Tell us about yourself. Please circle or check the answer that best describes you.

1. What is your gender?

male

female

2. What is your age range?
21 to 35 36 to 45
46 to 60 $60+$

3. What is the highest level of education you have completed?
a. some high school
b. graduate high school
c. trade or technical school
d. attended college
e. graduate or professional

4. Your total family income before taxes is:
a. Under $\$ 20,000$
b. $\$ 20,000-\$ 30,000$
c. $\$ 30,000-\$ 40,000$
d. $\$ 40,000-\$ 50,000$
e. $\$ 50,000-\$ 70,000$
f. $\$ 70,000-\$ 90,000$
g. $\$ 90,000+$

5. Number of persons in your household.

6. Do you own your own home?

Yes No

7. Where do you live?
a. city
b. suburb
c. rural area

8. Your current employment status is:
a. employed full-time
b. employed part-time
c. not employed
d. retired or disabled

9. Is your current employment considered a profession? (such as doctor, lawyer, teacher, minister) Yes No

10. Are you a skilled tradesperson, technician, or administrative support?

Yes No

11. Do you own your own business or practice?

Yes No

12. What is your marital status?
a. married
b. widowed
c. divorced
d. never married
e. sharing a home with a partner 
13. Are you currently a member of a church?

Yes

No

14. What is your religious preference or denominational affiliation?

15. How often do you attend church?
a. once or twice per year
b. once per month
c. at least twice per month
d. once a week
e. only on special occasions ( e.g. holidays, weddings, funerals, programs)

16. How do you describe your race/ ethnicity?
a. African- American
b. Caribbean-American
c. Black Hispanic
d. Multiracial
e. Other (please describe)

17. Would you consider joining a non-A frican American church? definitely yes definitely no would consider

\section{Please circle the following items on the scale of importance.}

Key: $1=$ not applicable, $2=$ not important, $3=$ important but not necessary, $4=$ very important, $5=$ essential

1. Which of the following are or would be important factors in your decision to join a church?
a. Nearest church in my denomination
b. Nearest church to my home
c. Biblical teachings
d. Style of worship
e. Family, friends, or neighbors are members
f. Ministries that are sensitive to my needs or concerns
g. Quality of the sermons
h. Ministry/discipleship opportunities
i. Reputation or influence of the church
j. Reputation or influence of the pastor

$\begin{array}{lllll}1 & 2 & 3 & 4 & 5 \\ 1 & 2 & 3 & 4 & 5 \\ 1 & 2 & 3 & 4 & 5 \\ 1 & 2 & 3 & 4 & 5 \\ 1 & 2 & 3 & 4 & 5 \\ 1 & 2 & 3 & 4 & 5 \\ 1 & 2 & 3 & 4 & 5 \\ 1 & 2 & 3 & 4 & 5 \\ 1 & 2 & 3 & 4 & 5 \\ 1 & 2 & 3 & 4 & 5\end{array}$

2. What emphasis would you like to see your church give to the following areas

a. Marriage counseling and support

b. Parenting

c. Homelessness/hunger

d. Career development / job placement

e. Singleness

f. Aging/senior issues

g. Personal finance

h. Sexuality

i. Substance use and abuse

j. Educational opportunities and advancement

k. Racial concerns

1. Political issues (voting and civil rights)

m. Teen pregnancy

n. African-American health issues

o. AIDS

p. Criminal justice

q. Support for families and children of incarcerated

$\begin{array}{lllll}1 & 2 & 3 & 4 & 5 \\ 1 & 2 & 3 & 4 & 5 \\ 1 & 2 & 3 & 4 & 5 \\ 1 & 2 & 3 & 4 & 5 \\ 1 & 2 & 3 & 4 & 5 \\ 1 & 2 & 3 & 4 & 5 \\ 1 & 2 & 3 & 4 & 5 \\ 1 & 2 & 3 & 4 & 5 \\ 1 & 2 & 3 & 4 & 5 \\ 1 & 2 & 3 & 4 & 5 \\ 1 & 2 & 3 & 4 & 5 \\ 1 & 2 & 3 & 4 & 5 \\ 1 & 2 & 3 & 4 & 5 \\ 1 & 2 & 3 & 4 & 5 \\ 1 & 2 & 3 & 4 & 5 \\ 1 & 2 & 3 & 4 & 5 \\ 1 & 2 & 3 & 4 & 5\end{array}$


r. Other

3. What forms of evangelism is most effective?

a. Tent meeting

b. Church revival

c. Mass media (television, radio, newspaper ads)

d. Special events (programs, concerts, Christmas play, etc...)

e. One on one Bible study

f. Prophesy seminars

g. Lifestyle evangelism

h. Small group evangelism

$\begin{array}{lllll}1 & 2 & 3 & 4 & 5 \\ 1 & 2 & 3 & 4 & 5 \\ 1 & 2 & 3 & 4 & 5 \\ 1 & 2 & 3 & 4 & 5 \\ 1 & 2 & 3 & 4 & 5 \\ 1 & 2 & 3 & 4 & 5 \\ 1 & 2 & 3 & 4 & 5 \\ 1 & 2 & 3 & 4 & 5\end{array}$

4. What elements are most important to you in worship services?
a. Biblical content
b. Ability of the preacher
c. Music
d. Participation of the worshipers
e. Prayer

$\begin{array}{lllll}1 & 2 & 3 & 4 & 5 \\ 1 & 2 & 3 & 4 & 5 \\ 1 & 2 & 3 & 4 & 5 \\ 1 & 2 & 3 & 4 & 5 \\ 1 & 2 & 3 & 4 & 5\end{array}$

5. What style of worship do you find meaningful?
a. Traditional mainline Protestant
b. Catholic/ Episcopal liturgy
c. Conservative/traditional African-American
d. Pentecostal/ charismatic
e. Contemporary Christian

$\begin{array}{lllll}1 & 2 & 3 & 4 & 5 \\ 1 & 2 & 3 & 4 & 5 \\ 1 & 2 & 3 & 4 & 5 \\ 1 & 2 & 3 & 4 & 5 \\ 1 & 2 & 3 & 4 & 5\end{array}$

6. What is the role of the pastor?
a. Worship leader
b. Interpreter of the Word
c. Counselor/spiritual advisor
d. Community activist

$\begin{array}{lllll}1 & 2 & 3 & 4 & 5 \\ 1 & 2 & 3 & 4 & 5 \\ 1 & 2 & 3 & 4 & 5 \\ 1 & 2 & 3 & 4 & 5\end{array}$




\section{BIBLIOGRAPHY}

"Annual Update of the HHS Poverty Guidelines." Federal Register, 18 February 2005, 8373-8375.

Akbar, Na'im. Visions for Black Men. Tallahassee, FL: Mind Productions and Associates, 1991.

Anderson, Claude. Black Labor, Whites Wealth: The Search for Power and Economic Justice. Bethesda: PowerNomics Corporation, 1994.

Anderson, Margaret L. "Studying across Difference: Race; Class and Gender in Qualitative Research." In Race and Ethnicity in Research Methods, ed. John H. Stanfield and Rutledge M. Dennis. Newbury Park, CA: Sage Publications, 1993.

Ashmede, R.W. African American West Indian: Friend or Foe. Jamaica, NY: Claremont Publishing Co., 1991.

Bacote, Vincent. "Theological Method in Black and White." In The Gospel in Black and White: Theological Resources for Racial Reconciliation, ed. Dennis L. Okholm, 48-57. Downers Grove, IL: Intervarsity Press, 1997.

Baker, Delbert. The Unknown Prophet. Hagerstown, MD: Review and Herald Publishing Association, 1987.

, ed. Make Us One: Celebrating Spiritual Unity in the Midst of Cultural Diversity, Removing Barriers, Building Bridges. Boise, ID: Pacific Press Publishing Association, 1995.

Banner-Haley, Charles T. The Fruits of Integration: Black Middle Class Ideology and Culture, 1960-1990. Jackson, MS: University Press of Mississippi, 1994.

Barclay, William. The Letters of James and Peter. Rev. ed. Philadelphia: Westminster Press, 1976.

Barna, George. Church Marketing: Breaking Ground for the Harvest. Ventura, CA: Regal Books, 1992. . User Friendly Churches: What Christians Need to Know About the Churches People Love to Go To. Ventura, CA: Regal Books, 1991. 
. The Power of Vision: How You Can Capture and Apply God's Vision for Your Ministry. Ventura, CA: Regal Books, 1992.

Barna, George, and Mark Hatch. Boiling Point: How Coming Cultural Shifts Will Change Your Life. Ventura, CA: Regal Books, 2001.

Barna, George, and Harry R. Jackson. High Impact African-American Churches:

Leadership Concepts from Today's Most Effective Churches. Ventura, CA: Regal, 2004.

Bell, Derrick. Faces at the Bottom of the Well: The Permanence of Racism. New York: 1992.

ben-Jochannan, Yoseph A. A. African Origins of the Major "Western Religions." Baltimore: Black Classic Press, 1991.

Benz, Carolyn R., and Isadore Newman. The Qualitative-Quantitative Research Methodology: Exploring the Interactive Continuum. Carbondale, IL: Southern Illinois University Press, 1998.

Berry, Mary Frances. Black Resistance, White Law: A History of Constitutional Racism in America. New York: Penguin Books, 1995.

Birch, Bruce C., and Larry L. Rasmussen. The Predicament of the Prosperous. Philadelphia: Westminster Press, 1978.

Birchett, Colleen. Biblical Strategies for a Community in Crises: What African Americans Can Do. Chicago: Umi Publication, 1992.

Billingsly, Andrew. Black Families in Whites America. Englewood Cliffs, NJ: PrenticeHall, 1968. . Climbing Jacob's Ladder: The Enduring Legacy of African American Families. New York: Simon and Schuster, 1992.

Blaiklock, E. M. The Acts of the Apostles: An Historical Commentary. Grand Rapids, MI: Wm. B. Eerdmans Publishing Company, 1959.

Blauner, Bob. Black Lives, White Lives: Three Decades of Race Relations in America. Berkeley, CA: University of California Press, 1999.

Bloom, Harold. The American Religion: The Emergence of the Post-Christian Nation. New York: Simon and Schuster, 1992.

Blue, Elfreda V. "How Middle School Students with Learning Disabilities Read and Respond to Literary Text." Ph.D. diss., State University of New York at Buffalo. 
Blyden, Edward W. Christianity, Islam, and the Negro Race. Baltimore: Black Classic Press, 1994.

Boston. Kevin. Smart Money Moves for African Americans. New York: G. P. Putnam's Sons, 1996.

Branch, Taylor. Parting the Waters: America in the King Years, 1954-63. New York: A Touchstone Book, Simon and Schuster, 1988.

Branch, Taylor. Pillars of Fire: America in the King Years, 1963-65. New York: Simon and Schuster, 1998.

Bradford, Charles E. Sabbath Roots: The African Connection. Barre, VT: L. Brown and Sons Printing, for the Ministerial Association of the General Conference of Seventh-day Adventists, 1999.

Branson, Roy. “Adventism's Rainbow Coalition." In Make Us One: Celebrating Spiritual Unity in the Midst of Cultural Diversity, Removing Barriers, Building Bridges, ed. Delbert W. Baker, 60-82. Boise, ID: Pacific Press, 1995.

Brown, Raymond E. An Introduction to the New Testament. New York: Doubleday, 1997.

Brown, Tony. Black Lies, White Lies: The Truth According to Tony Brown. New York: William Morrow and Company, 1995.

Bruce, F. F. The Acts of the Apostles: The Greek Text with Introduction and Commentary. Grand Rapids: Wm. B. Eerdmans Publishing Company, 1965.

Buchanan, Patrick. The Death of the West: How Dying Populations and Immigration Invasions Imperil Our Country and Civilization. New York: Thomas Dunne Books, 2002.

Burgess, John. Black Gospel, White Church. New York: Seabury Press, 1982.

Burton, Keith. We've Come This Far by Faith: And Other Spiritually Awakening Essays. Huntsville, AL: A Voice in the Wilderness Publishers, 1996.

Carter, Stephen L. The Culture of Disbelief: How American Law and Politics Trivialize Religious Devotion. New York: Basic Books, 1993. . Reflections of an Affirmative Action Baby. New York: Basic Books, 1991.

Cartwright, Michael C. "Wresting the Scriptures." In The Gospel in Black and White: Theological Resources for Racial Reconciliation, ed. Dennis L. Okholm, 71-114. Downers Grove, IL: Inter Varsity Press, 1997. 
Cashin, Sheryll. The Failure of Integration: How Race and Class Are Undermining the American Dream. New York: Public Affairs, 2004.

Chideya, Farai. Don't Believe the Hype: Fighting Cultural Misinformation about African-Americans. New York: Plume Book by Penguin Press, 1995.

Cone, James H. A Black Theology of Liberation: Twentieth Anniversary Edition. Maryknoll: Orbis Books, 2000.

Cone, James H., and Gayraud S. Wilmore, eds. Black Theology: A Documented History. Vol. 2, 1980-1992. Maryknoll, NY: Orbis Books, 1996.

Conn, Harvie M. Planting and Growing Churches: From Dream to Reality. Edited by Harvie M. Conn. Grand Rapids, MI: Baker Books, 1997.

Cooper, Rod. "People Just Like Me: Does the Bible Give Us Freedom to Build Deliberately Homogeneous Churches? In Building Unity in the Church of the New Millenniu, ed. Dwight Perry, 153-165. Chicago: Moody Press, 2002.

Cooper, Rodney L. We Stand Together: Reconciling Men of Different Color. Chicago: Moody Press, 1995.

Cose, Ellis. “The Black Gender Gap.” Newsweek, 3 March 2003, 46-51.

. Color Blind: Seeing Beyond Race in a Race-Obsessed World. New York: Harper Collins, 1997.

. The Envy of the World: On Being a Black Man in America. New York:

Washington Square Press, 2002.

. The Rage of the Privileged Class: Why Are Middle Class Blacks Angry? Why Should America Care? New York: Harper Collins, 1993.

Costen, Melva Wilson. African American Christian Worship. Nashville, TN: Abingdon Press, 1993.

Davis, F. James. Who Is Black? One Nation's Definition. University Park, PA:

Pennsylvania State University Press, 1991.

Dent, David, J. In Search of Black America: Discovering the African-American Dream. New York: Simon and Schuster, 2000.

Denzin, N. K., and Y. S. Lincoln. Handbook of Qualitative Research. Thousand Oaks, CA: Sage, 1984. 
Dodds, Elreta. Slaves Obey Your Masters: What the Bible Really Says About Slavery. Nashville, TN: James C. Winston Publishing Company, 1996.

DuBois, W.E.B. The Negro American Family. Cambridge, MA: MIT Press, 1970. . The Souls of Black Folk. New York: Penguin Books, 1989.

Drucker, Peter, F. Managing the Future: The 1990's and Beyond. New York: Plume/ Penguin, 1992.

Dudley, Charles Edward. Thou Who Hath Brought Us: The Story of the Growth and Development of the Seventh-day Adventist Denomination as It Relates to AfricanAmericans. Brushton, NY: Teach Services, 1997.

El Nasser, Haya. "Black America's New Diversity: Immigrants from Africa, Caribbean Making Their Voices Heard." USA Today, 17 February 2003, 3A.

Feagin, Joe R., and Melvin B. Sikes. Living with Racism: the Black Middle Class Experience. Boston, MA: Beacon Press, 1994.

Felder, Cain Hope. Stony the Road We Trod: African American Biblical Interpretation. Minneapolis: Fortress Press, 1991. Troubling Biblical Waters: Race, Class, and Family. Maryknoll, NY: Orbis Books, 1997.

Francis, Hozell C. Church Planting in the African-American Context. Grand Rapids, MI: Zondervan Publishing, 1999.

Franklin, John Hope. From Slavery to Freedom. New York: McGraw Hill, 1994.

Fraser, Steven, ed. The Bell Curve Wars. New York: Basic Books, 1995.

Frazier, E. Franklin. The Black Bourgeoisie. New York: Collier Books, 1957. . The Negro Family in the United States. Chicago: University of Chicago Press, 1939.

Friedman, Murray. Overcoming Middle Class Rage. Philadelphia, PA: Westminister Press, 1971.

Frye, Barbara. "Diversity and the Family Forum." In Make Us One: Celebrating Spiritual Unity in the Midst of Cultural Diversity, Removing Barriers, Building Bridges, ed. Delbert W. Baker, 139-158. Boise, ID: Pacific Press, 1995. 
Fulop, Timothy E., and Albert J. Raboteau, eds. African-American Religion: Interpretive Essays in History and Culture. New York: Routledge, 1997.

Fussell, Paul. Class: A Guide through the American Status System. New York: Touchstone, Simon \& Schuster, 1983.

Fultz, Michael. "The Morning Cometh: African American Periodicals, Education and the Black Middle Class, 1900-1930." Journal of Negro History 80 (1995): 97-101.

Gallop, George, and Michael D. Lindsay. The Gallop Guide: Reality Check for Twentyfirst Century Churches. Loveland, CO: Group, 2002.

Galloway, Dale. Leading in Times of Change. Kansas City, MO: Beacon Hill Press, 2001.

Gates, Henry Louis, Jr. "Frontline: The Two Nations of Black America." http://www.pbs.org/wgbh (Accessed 9 November 2004).

Graham, Lawrence Otis. Our Kind of People: Inside America's Black Upper Class. New York: Harper Collins, 1999.

Grant, George. Bring in the Sheaves: Transforming Poverty into Productivity. Brentwood, TN: Wolgemuth and Hyatt, 1988.

Grant, Joanne, ed. Black Protest: History Documents and Analyses, 1619 to the Present. Greenwich, CT: Fawcett Publications, 1968.

Greenway, Roger S., ed. Discipling the City: Theological Reflections on Urban Mission. Grand Rapids: Baker Book House, 1979.

Hacker, Andrew. Two Nations: Black and White, Separate, Hostile, and Unequal. New York: Ballantine Books, 1992.

Hadaway, C. Kirk. "Learning from Urban Research.” In Planting and Growing Urban Churches: From Dream to Reality, ed. Harvie M. Conn, 35-45. Grand Rapids, MI: Baker Books, 1997.

Haechen, Ernst. The Acts of the Apostles: A Commentary. Oxford: Basil Blackwell, 1971.

Hale, Frank W., Jr. A Letter to African American Males. Bloomington, IN: $1^{\text {st }}$ Books, 2000. 
Hanegraff, Hank. What's Wrong with the Faith Movement (Part One): E.W. Kenyon and the Twelve Apostles of Another Gospel. Santa Margarita, CA: Christian Research Institute. Available at www.equip.org/free/DC755-1.htm (Accessed 30 April 2005).

Hansbury, Loraine. A Raisin in the Sun. New York: Signet Books, 1958.

Harris, Hamil. “Growing in Glory.” Emerge, April 1977, 49-53.

Heath, Brad. "Prosperity Can't Close Metro Area Income." Detroit News, 10 September 2002, http://www.detnews.com/2002/census/0212/19/a01-583173.htm (Accessed 18 November 2004).

Herrnstein, R., and C. Murray. The Bell Curve: Intelligence, Class Structure in America. New York: Free Press, 1994.

Hesselgrave, David J. Communicating Christ Cross-Culturally: An Introduction to Missionary Communication. $2^{\text {nd }}$ ed. Grand Rapids: Zondervan, 1990.

Hiebert, Paul G. Anthropological Insights for Missionaries. Grand Rapids: Baker Books, 1985.

. "Culture and Cross-Cultural Differences in Missions." In Perspectives on the World Christian Movement: A Reader, ed. Ralph D. Winter and Steven G.

Hawthorne. Pasadena, CA: William Carey Library, 1991.

Hill, Robert. The Strength of the African American Family: Twenty Five Years Later. Lanham, MD: University Press of America, 1999.

Hopkins, Dwight N. Down, Up and Over: Slave Religion and Black Theology. Minneapolis: Fortress Press, 2000.

. Head and Heart: Black Theology-Past Present and Future. New York: Pelgrave, 2002.

Hopkins, Dwight N., and George Cummings, eds. Cut Loose Your Stammering Tongue: Black Theology in the Slave Narratives. Maryknoll, NY: Orbis Books, 1998.

Hove, Richard. Equal in Christ? Galations 3:28 and the Gender Dispute. Wheaton, IL: Crossway Books, 1999.

Hubbard, Dolan. The Sermon and the African American Literary Imagination. Columbia, MO: University of Missouri Press, 1994.

Hudson, Kelly. "Inner City Churches on the Move." Religion and Ethics Newsweekly, 6 February 2004, 5-12. 
Hutchinson, Earl Ofari. The Assassination of the Black Male Image. Los Angeles: Middle Passage Press, 1994.

"Injustice Index: The Black Middle Class." May 2004. http://www.drummajorinstitute.org/plugin/template/dm:/44/2369 (Accessed 13 February 2005).

Jackson, John G. Introduction to African Civilizations. Secaucus, NJ: Citadel Press, 1970.

Jackson, John G. Christianity Before the Christ. Austin, TX: American Atheist Press, 1985.

Jackson, Terrance. Putting It All Together: World Conquest, Global Genocide and African Liberation. New York: Akasa Press, 1991.

Jacobson, Henry. The Good Life. Wheaton, IL: Victor Books, 1981.

Jacques-Garvey, Amy. Philosophy and Opinions of Marcus Garvey. New York: Anthenum, 1992.

"James." Seventh-day Adventist Bible Commentary. Edited by Francis D. Nichol. Washington, DC: Review and Herald, 1953-1957. 7:517.

James, Davis F. Who Is Black? One Nation's Definition. University Park, PA: Pennsylvania State University Press, 1991.

James, George G. M. Stolen Legacy: Greek Philosophy Is Stolen Egyptian Philosophy. Newport News, VA: United Brothers Communications Systems, 1989.

Jeffries, James S. The Greco-Roman World of the New Testament Era: Exploring the Background of Early Christianity. Downer's Grove, IL: InterVarsity Press, 1999.

Johnson, William G. The Fragmenting of Adventism: Ten Issues Threatening the Church Today, Why the Next Five Years Are Crucial. Boise, ID: Pacific Press, 1995.

Johnston, Robert C., and Debra Viadero. "Unmet Promise: Raising Minority Achievement." Education Week 19, no.27 (15 March 2000): 1, 18-21.

Jones, Charisse, and Kumea Shorter-Gooden. Shifting: The Double Lives of Black Women in America. New York: HarperCollins, 2003.

Katzman, Martin T., and Harold Childs. "Black Flight: The Middle Class Black Reaction to School Integration and Metropolitan Change." Database on-line. http://eric.gov.ERICWebPortal (Accessed 23 February 2005). 
Keener, Craig S., and Glen Usry. Defending Black Faith: Answers to Tough Questions African-American Christianity. Downers Grove, IL: InterVarsity Press, 1997.

Kinchelo, J.L., Shirley R. Steinberg, Nelson M. Rodriguez, and Ronald E. Chennault. White Reign: Deploying Whiteness in America. New York: St. Martin's Press, 1998.

Kitwana, Bakar. The Hip Hop Generation: Young Blacks and the Crises in African American Culture. New York: Basic Civitas Books, 2002.

Kochman, Thomas. Black and Whites: Styles in Conflict. Chicago: University of Chicago Press, 1981.

Kondo, Baba Zak A. For Homeboys Only: Arming and Strengthening Young Brothers For Black Manhood. Vol. 1. Washington, DC: Nubia Press,1991.

Koretz, Gene. "Economic Trends: Great Strides for US Blacks," Business Week, 3 September 2001. http://www.businessweek.com/magazine/ content/01_36/c3747033.htm (Accessed 13 February 2005).

Kubo, Sakae. The God of Relationships: How the Gospel Helps Us to Reach Across Barriers Such as Race, Culture, and Gender. Hagerstown, MD: Review and Herald Publishing Association, 1993.

Kunjufu, Jawanza. Countering the Conspiracy to Destroy Black Boys. Chicago: African American Images, 1985.

. Countering the Conspiracy to Destroy Black Boys. Vol. 2. Chicago: African American Images, 1986.

. Motivating and Preparing Black Youth to Work. Chicago: African American Images, 1986.

Ladd, George Elden. A Theology of the New Testament. Grand Rapids, MI: Wm. B. Eerdmans Publishing Company, 1974.

Landry, Bart. The New Black Middle Class. Berkeley, CA: University of California Press, 1987.

Landry, Bart, and Margaret Platt. "The Employment of Wives in Middle-Class Black Families." Journal of Marriage and Family 40, no. 4 (1978): 787-97.

Laurie, Greg. The Upside Down Church. Wheaton, IL: Tyndale House Publishers, 1999.

Laws, Sophie. A Commentary on the Epistle of James. Harper's New Testament Commentaries. San Francisco: Harper and Row, 1980. 
Lenski, R. C. H. The Interpretation of the Acts of the Apostles. Columbus, OH: Wartburg Press, 1944.

Lewin, Arthur. "A Tale of Two Classes: The Black Poor and the Black Middle Class." Black Scholar 21, no. 3 (1990-91): 7-13.

Lincoln, C. Eric, and Lawrence H. Mamiya. The Black Church in the African American Experience. Durham, NC: Duke University Press, 1990.

Logan, Richard. Maternal Child Rearing Patterns and Children's Scholastic Achievement in Different Groups. http://www.eric.ed.gov/ ERICWebPortal/Home (Accessed 25 February, 2005).

Lo, Jim. Intentional Diversity: Creating Cross-Cultural Ministry Relationships in Your Church. Indianapolis: Wesleyan Publishing House, 2002.

Loury, Glenn C. "Why More Blacks Don't Invest." The New York Times Sunday Magazine, 7 June 1998. www.bu.edu/irsd/articles/whyinvest.htm (Accessed 18 October, 2004).

Madhubuti, Haki R. "Five Most Often Used Excuses Black Men Give Black Women." In Black Men, Obsolete, Single, Dangerous? The Afrikan American Family in Transition. Chicago: Third World Press, 1990.

Majors, Richard, and Janet Mancini Billson. Cool Pose: The Dilemmas of Black Manhood in America. New York: Touchstone, Simon and Schuster, 1992.

Malina, Bruce J. The New Testament World: Insights from Cultural Anthropology. Atlanta: John Knox Press, 1981.

Mains, David. Healing the Dysfunctional Church Family: When Destructive Family Patterns Infiltrate the Body of Christ. Wheaton, IL: Victor Books, 1992.

Malphurs, Aubrey. Values-Driven Leadership: Discovering and Developing Your Core Values for Ministry. Grand Rapids, MI: Baker Books, 1996.

Marable, Manning. Black Leadership. New York: Columbia University Press, 1998.

Massey, James Earl. Designing the Sermon: Order and Movement in Preaching. Nashville: Abingdon, 1980.

Matthews, Jay. "Blacks Battle Achievement Gap: Parents Unite to Make Sure Children Aren't Shortchanged." Washington Post, 31 December, 2000. http://www.washingtonpost.com/ac2/wp-dyn/A2297-2000 (Accessed 12 December 2002). 
Mathis, Deborah. Yet a Stranger: Why Black Americans Still Don't Feel at Home. New York: Warner Books, 2002.

Maynard-Reid, Pedrito. Diverse Worship: African-American, Caribbean \& Hispanic Perspectives. Downers Grove, IL: InterVarsity Press, 2000.

McAdoo, Harriette Pipes. Black Families. Beverly Hills: Sage Publications, 1981. . The Extended Kin Network and Socialization of Children in Upwardly Mobile Black Families.” ERIC Document Reproduction Service No.18514. http://www.eric.ed.gov/ ERICWebPortal/Home (Accessed 20 February 2005).

McArthur, John. Christ Our Sufficiency. Dallas, TX: Word, 1991.

McCray, Walter Arthur. The Black Presence in the Bible and the Table of Nations Genesis 10:1-32: With Emphasis on the Hamitic Genealogical Line from a Black Perspective. Chicago: Black Light Fellowship, 1990.

McGavran, Donald H. Understanding Church Growth. Grand Rapids, MI: William B. Eerdmans Publishing Co., 1970.

McGavran, Donald A., and Winfield C. Arn. Ten Steps for Church Growth. San Francisco, CA: Harper and Row, 1977.

McIntyre, Charshee C. L. Criminalizing a Race: Free Blacks During Slavery. NewYork: Kayode Publications, 1992.

McMickle, Marvin A. Preaching to the Black Middle Class: Words of Challenge, Words of Hope. Valley Forge, PA: Judson Press, 2000.

Mbiti, John S. Introduction to African Religion. London: Heinemann Educational Books, 1975.

Meeks, Kenneth. Driving While Black, Highways, Shopping Malls, Taxicabs, Sidewalks: What to Do if You Are a Victim of Racial Profiling. New York: Broadway Books, 2000.

Mercer, Larry. "Dismantling Class Barriers: Can the Church Avoid Wealth-based Prejudice?" In Building Unity in the Church of the New Millennium, ed. Dwight Perry, 141-152. Chicago: Moody Press, 2002.

"Middle Class 2003: How Congress Voted." http://www.drummajorinstitute.org/ plugin/template/dmi/27/2322 (Accessed 21 February 2005).

"Middle Class: Sociological Debates Concerning Definition." Wikipedia, http://en.wikipedia.org/wiki/middle_class (Accessed 21 February 2005). 
Miller, John M. The Contentious Community: Constructive Conflict in the Church. Philadelphia: Westminster Press, 1978.

Mitchell, Henry H. Black Preaching: The Recovery of a Powerful Art. Nashville: Abingdon Press, 1990.

Moore, Joan W., and Burton M. Moore. Social Problems. Englewood Cliffs, NJ: Prentice Hall, 1982.

Moulton, Harold K. The Analytical Greek Lexicon. Grand Rapids, MI: Zondervan, 1978.

Mosley, William. What Color Was Jesus? Chicago: African American Images, 1987.

Moyd, Olin P. The Sacred Art: Preaching and Theology in the African American Tradition. Valley Forge, PA: Judson Press, 1995.

Moynahan, Daniel P. "The Negro Family: A Case for National Action.” In The Moynahan Report and the Politics of Controversy, ed. Lee Rainwater and William Yancey. Cambridge, MA: MIT Press, 1967.

"New York Families: America's Juggling Act; Who Is the Middle Class?" WSKU Transcript, April 2001. http://www.wsku.org/news/features/ familyseries/middleclass transcript. html (Accessed 21 February 2005).

Niebuhr, Reinhold. Moral Man \& Immoral Society: A Study in Ethics and Politics. Louisville, KY: Westminster John Knox Press, 2001.

Niebuhr, H. Richard. The Social Sources of Denominationalism. New York: Meridian, New American Library, 1975.

Nichol, Francis D., ed. Seventh-day Adventist Bible Commentary Tools. Washington, DC: Review and Herald, 1953-1957.

Okholm, Dennis L., ed. The Gospel in Black and White: Theological Resources for Racial Reconciliation. Downers Grove, IL: InterVarsity Press, 1997.

Oliver, Roland. The African Experience: Major Themes in African History from Earliest Times to the Present. New York: Harper Collins, 1991.

Osborne, Richard. "Floppy Disk Event or Revolutionary Summit?” Adventist Review, 2 December 1999, 10-11.

Patillo, Mary E. "Sweet Mothers and Gangbangers: Managing Crime in a Black Middle Class Neighborhood.” Social Forces 76, no. 3 (March 1998): 747-754. 
Patillo-McCoy, Mary. Black Picket Fences: Privilege and Peril Among the Black Middle Class. Chicago: University of Chicago Press, 1999.

Patton, D. C. Qualitative Evaluation and Research Methods. Newbury Park, CA: Sage Publications, 1990.

Patton, M. Q. Qualitative Evaluation Methods. Beverly Hills, CA: Sage Publications, 1989.

Peart, Norman Anthony. Separate No More: Understanding and Developing Racial Reconciliation in Your Church. Grand Rapids: Baker Books, 2000.

Perkins, John M., ed. Restoring At-Risk Communities: Doing It Together \& Doing It Right. Grand Rapids: Baker Books, 1995.

Perry, Dwight, ed. Building Unity in the Church of the New Millennium. Chicago: Moody Press, 2002.

Pocock, Michael. “Compass for the Journey.". In Cultural Change and Your Church: Helping Your Church Thrive in a Diverse Society, ed. Michael Pocock and Joseph Henriques. Grand Rapids, MI:: Baker Books, 2002.

Pocock, Michael, and Joseph Henriques, eds. Cultural Change \& Your Church: Helping Your Church Thrive in a Diverse Society. Grand Rapids: Baker Books, 2002.

Pollard, Leslie M., ed. Embracing Diversity: How to Understand and Reach People of All Cultures. Hagerstown, MD: Review and Herald Publishing Association, 2000.

Potter, Ronald C. "Race, Theological Discourse and the Continuing American Dilemma." In The Gospel in Black and White: Theological Resources for Racial Reconciliation, ed. Dennis L. Okholm, 27-36. Downers Grove, IL: Inter Varsity Press, 1997.

Project Wittenberg: Evangelism and Church Growth with Special Reference to the Church Growth Movement. A Report to the Commission on Theology and Church Relations of the Lutheran Church-Missouri Synod; September 1987.

Pugh, Tony. "Minorities Likely to Get Worse Mortgage Rate." Akron Beacon Journal 2 May 2002, http://www.butera-andrews.com/legislativeupdates/directory/Media/Articles/Subprime \%20News $\% 20 \mathrm{Clips} \% 2005-02-$ 2002.pdf (Accessed 18 November 2004).

Raboteau, Albert J. Slave Religion: The "Invisible Institution" in the Antebellum South. Oxford: Oxford University Press, 1978. 
Rauschenbusch, Walter. Christianity and the Social Crises. Louisville, KY: Westminster John Knox Press, 1991. . A Theology for the Social Gospel. Louisville, KY: Westminster John Knox Press, 1997.

Recommendations from the Delegates. Adventist Review, 2 December 1999, 11.

Reed, Gregory J. Economic Empowerment through the Church: A Blueprint for Progressive Community Development. Grand Rapids: Zondervan Publishing House, 1994.

Reynolds, Louis B. We Have Tomorrow: The Story of American Seventh-day Adventist with an African Heritage. Hagerstown, MD: Review and Herald Publishing Association, 1984.

Rivers, Eugene. "The Responsibility of Evangelical Intellectuals in the Age of White Supremacy." In The Gospel in Black and White: Theological Resources for Racial Reconciliation, 14-21. Downers Grove, IL: Inter Varsity Press, 1997.

Rock, Calvin, ed. Perspectives: Black Seventh-day Adventists Face the Twenty-first Century. Hagerstown, MD: Review and Herald Publishing Association, 1996.

Roetzel, Calvin J. The World That Shaped the New Testament. Atlanta: John Knox Press, 1985.

Rogers, J. A. From "Superman" to Man: A Fearless and Penetrating Discussion of America's Greatest Problem. St. Petersburg, FL: Helga M. Rogers,1968.

Rogers, J. A. World's Great Men of Color. New York: Macmillan Publishing Co., 1972.

Rosado, Caleb. "Challenges of Change in the Church Mission." In Make Us One: Celebrating Spiritual Unity in the Midst of Cultural Diversity, ed. Delbert W. Baker, 39-59. Boise, D: Pacific Press, 1995.

Rosen, Robert H., and Lisa Berger. The Healthy Company: Eight Strategies to Develop People, Productivity, and Profits. New York: Jeremy P. Tarcher/Perigree, 1991.

Ross, Alexander. The Epistles of James and John. London: Marshall, Morgan and Scott, 1963.

Ryan, William. Blaming the Victim. New York: Random House, 1976.

Sahlin, Monte. Adventist Congregations Today: New Evidence for Equipping Healthy Churches. Lincoln, NE: Center for Creative Ministry, 2003. 
Sample, Tex. Blue-collar Ministry: Facing Economic and Social Realties of Working People. Valley Forge, PA: Judson Press, 1984.

Scanzoni, J. "Sex, Roles, Economic Factors, and Marital Solidarity in Black and White Marriages. Journal of Marriage and Family 37, no. 1 (1975): 130-144.

Shuler, Clarence. Winning the Race to Unity: Is Racial Reconciliation Really Working? Chicago: Moody Press, 1998.

Schumer, Charles. "Capital Access: Lending Patterns in Black and Whites Neighborhoods Tell a Tale of Two Cities." Unpublished MS. http://schumer.senate.gov/SchumerWebsite/ media/capitalaccess.pdf (Accessed 18 November 2004).

Schwarz, Christian A. Natural Church Development: A Guide to Eight Essential Qualities of Healthy Churches. Carol Stream, IL: Church Smart Resources, 1998.

Sepulveda, Ciro. Ellen White on the Color Line: The Idea of Race in a Christian Community. Huntsville, AL: Biblos Press, 1997.

Seventh-day Adventist Bible Commentary. Edited by Francis D. Nichol. Washington, DC: Review and Herald, 1953-1957. 7:517.

Shipler, David K. A Country of Strangers: Blacks and Whites in America. New York: Alfred A. Knopf, 1997.

Sider, Ronald J. Just Generosity: A New Vision for Overcoming Poverty. Grand Rapids, MI: Baker Books, 1999.

Sider, Ronald J., Philip N. Olson, and Heidi Rolland Unruh. Churches That Make a Difference: Reaching Your Community with Good News and Good Works. Grand Rapids: Baker Books, 2002.

Seidman, I. E. Interviewing as Qualitative Research: $A$ Guide for Researchers in Education and Social Sciences. New York: Teachers College Press, 1991.

Smalley, William A. "Cultural Implications of an Indigenous Church.” In Perspective on the World Christian Movement: A Reader, ed. Ralph D. Winter and Steven C. Hawthorne. Pasadena, CA: William Carey Library, 1991.

Spencer, Jon Michael. Protest and Praise: Sacred Music of Black Religion. Minneapolis: Fortress Press, 1990.

Sprinthall, Richard C., Gregory T. Schmutte, and Lee Sirois. Understanding Educational Research. Englewood Cliffs, NJ: Prentice Hall, 1990. 
Southern, Eileen. The Music of Black Americans. New York: W.W. Norton and Co., 1971.

Staples, Brent. Parallel Time: Growing Up in Black and White. New York: Pantheon Books, 1994.

Staples, R. "Race, Liberalism, Conservatism, and Pre-Marital Permissiveness: A Biracial Comparison." Journal of Marriage and Family 40, no. 4 (1978): 733-742.

Steele, Shelby. The Content of Our Character: A New Vision of Race in America. New York: Harper Collins, 1990.

Steinhorn, Leonard, and Barbara Diggs-Brown. By the Color of Our Skin: The Illusion of Integration and the Reality of Race. New York: Plume, Penguin, 2000.

Stewart, Carlyle Fielding. African American Church Growth: 12 Principles for Prophetic Ministry. Nashville: Abingdon Press, 1994.

Stone, Howard W., and James O. Duke. How to Think Theologically. Minneapolis: Fortress Press, 1996.

Talty, Stephan. Mulatto America: At the Crossroads of Black and White Culture: $A$ Social History. New York: Harper Collins, 2003.

Tasker, R. V. G. The General Epistle of James: An Introduction and Commentary. Tyndale New Testament Commentary Series. Grand Rapids: Wm. B. Eerdmans Publishing Company, 1960.

Tatum, Beverly Daniel. Assimilation Blues, Black Families in White Communities: Who Succeeds and Why? New York: Basic Books, 1987.

Taylor, Eugene. Shadow Culture: Psychology and Spirituality in America. Washington, DC: Counterpoint, 1999.

Thomas, Latta R. Biblical Faith and the Black American. Valley Forge: Judson Press, 1976.

Tillich, Paul. Morality and Beyond. Louisville, KY: Westminster John Knox Press, 1995. . Theology of Culture. New York: Oxford Press, 1959.

Trussel, Jacqueline. "The Changing Face of Religion: The Suburbanization of the Black Church." Black and Christian.com, 20 January 2005, 3 http://www.blackandchristian.com/articles/academy/trussell-11-01.html (Accessed 9 November 2004). 
Uchitelle, Louis. "Rising Incomes Lift 1.1 Million Out of Poverty." The New York Times, 1 October 1999, http://www.courses.psu.edu/hd_fs/hd fs597_rxj9/censusincome.htm (Accessed 13 February 2005).

Van Sertima, Ivan. They Came Before Columbus. New York: Random House, 1976. , ed. Blacks in Science: Ancient and Modern. New Brunswick: Transaction Books, 1991.

Vander Broek. Breaking Barriers: The Possibilities of Christian Community in a Lonely World. Grand Rapids, MI: Brazos Press, 2002.

Volney, C.F. The Ruin of Empires. Baltimore: Black Classic Books, 1991.

Wagner, C. Peter. Churchquake: How the New Apostolic Reformation Is Shaking the Church as We Know It. Ventura, CA: Regal, 1999.

Walker, Wyatt Tee. "Somebody's Calling My Name": Black Music and Social Change. Valley Forge, PA: Judson Press, 1992.

Warren, Rick. The Purpose Driven Church: Growth without Compromising Your Message and Mission. Grand Rapids, MI: Zondervan Publishing House, 1995.

Washington, James M., ed. A Testament of Hope: The Essential Writings and Speeches of Martin Luther King, Jr. New York: Harper Collins, 1986.

Washington, Joseph R. Black Sects and Cults: The Power Axis in an Ethnic Ethic. Garden City, NY: Anchor Press/Doubleday, 1973.

Washington, Raleigh B. "The Alternative to Ethnic-Focused Church Planting: How Can We Build Diversity as We Build Churches?" In Building Unity in the Church of the New Millennium, ed. Dwight Perry, pp. 112-113. Chicago: Moody Press, 2002.

Washington, Raleigh, and Glen Kehern. Breaking Down Walls: A Model for Reconciliation in an Age of Racial Strife. Chicago: Moody Press, 1993.

Webster's New World Dictionary of the American Language. 2nd collegiate ed. Edited by David Guralink. New York: Simon and Schuster, 1982. S.v. "classism," "theory."

Wellum, Kirk. "An Evaluation of the Church Growth Movement." http://www.xelco.on.ca/ sgcc/chm.htm (Accessed 18 January 2005).

White, Ellen G. Christ's Object Lessons. Battle Creek, MI: Review and Herald Publishing Co., 1900. 
. Desire of Ages. Mountain View, CA: Pacific Press, 1940.

. In Heavenly Places. Washington, DC: Review and Herald Publishing Association, 1967.

. Medical Ministry. Mountain View, CA: Pacific Press, 1932.

. The Southern Work. Washington, DC: Review and Herald Publishing Association, 1966.

Williams, Juan, and Dwayne Ashley. I'll Find a Way or I'll Make One: A Tribute to Historically Black Colleges and Universities. New York: Amistad/Harper Collins Publishers, 2004.

Williams, Lena. It's the Little Things: The Everyday Interactions That Get under the Skin of Blacks and Whites. New York: Harcourt, 2000.

Williams, Richard. They Stole It But You Must Return It. Rochester, NY: HEME Publishing, 1990.

. Torches: On the Road of Passage (A Guide for Black Males). Rochester, NY: HEMA Publishing, 2001.

Wilmore, Gayraud S. Black Religion and Black Radicalism: An Interpretation of the Religious History of African Americans. Maryknoll, NY: Orbis Books, 1998.

Wilson, Amos N. Black on Black Violence: The Psychodynamics of Black Self Annihilation in the Service of White Domination. New York: African World Infosystems, 1990 .

Witte, Griff, and Nell Henderson, "Wealth Gap Widens for Black, Hispanics." The Washington Post, 18 October, 2004, A11. http://www.washingtonpost.com/wpdyn/ articles/A40455-2004Oct17.html (Accessed 13 February 2004).

Woodley, Randy. Living in Color: Embracing God's Passion for Diversity. Grand Rapids, MI: Chosen Books, 2001.

Woodson, Carter G. The History of the Negro Church. Washington, DC: Associated Publishers, 1972. . The Mis-education of the Negro. Trenton, NJ: AfricaWorld Press, 1990.

Wright, Bobby. The Psychopathic Racial Personality and Other Essays. Chicago: Third World Press, 1994. 
Wright, Bruce. Black Robes, Whites Justice: Why Our Legal System Doesn't Work for Blacks. New York: Kensington Publishing Corporation, 1993. 
V I T A

\title{
DEDRICK L. B L UE
}

\author{
110 Mar Jo Lane \\ Harvest, AL 35749 \\ 256-858-2191
}

\section{EXPERIENCE}

20002-present Oakwood College, Huntsville, AL

- Vice President for Student Services

2001-2002 Oakwood College, Huntsville, AL

- Director of Spiritual Life/Chaplain

1997-2001 Northeastern Conference of Seventh- day Adventists, Rochester, NY

- Assistant to the President

1993-1997 Northeastern Conference of Seventh-day Adventists, Buffalo, NY

- Pastor, Emmanuel Temple of Seventh-day

1990-1993 Northeastern Conference of Seventh-day Adventists, Westbury, NY

- Pastor, Bethany Seventb-day Adventist Cburch

1987-1990 Northeastern Conference of Seventh-day Adventists, Rochester, NY

- Pastor, Breath of Life Seventh-day Adventist Church

1985-1990 Northeastern Conference of Seventh-day Adventists, Sodus, NY

- Pastor, Antioch Seventh-day Adventist Church

1985-1987 Northeastern Conference of Seventh-day Adventists, Rochester, NY

- Assistant Pastor, Jefferson Avenue Seventh-day Adventist Cburch

1999-2005 Andrews University, Berrien Spring, MI

- Enrolled in Doctor of Ministry program

State University of New York, Buffalo, NY

- Enrolled in Counselor Education Ph.D program

Colgate Rochester Divinity School, Rochester, NY

- Enrolled in Doctor of Ministry Program

Andrews University, Berrien Springs, MI

- Graduated, Master of Divinity

Oakwood College, Huntsville, AL

- Graduated magna cum laude, BA Theology 